\author{
UNIVERSITY OF SÃO PAULO \\ FACULTY OF ANIMAL SCIENCE AND FOOD ENGINEERING
}

HENRIQUE BARBOSA HOOPER

Physiological implications, cellular responses and lactational performance of Saanen goats under heat stress

Pirassununga 
HENRIQUE BARBOSA HOOPER

\title{
Physiological implications, cellular responses and lactational performance of Saanen goats under heat stress
}

\author{
VERSÃO CORRIGIDA
}

Thesis presented to the Faculty of Animal Science and Food Engineering, University of São Paulo, as part of the requirements to obtain the degree of Ph.D. in Science.

Concentration area: Animal Quality and Productivity

Supervisor: Prof. Dr. João Alberto Negrão

Co-supervisor: Prof.(a) Dr.(a) Cristiane Gonçalves Titto

Pirassununga 
Ficha catalográfica elaborada pelo

Serviço de Biblioteca e Informação, FZEA/USP,

com os dados fornecidos pelo(a) autor(a)

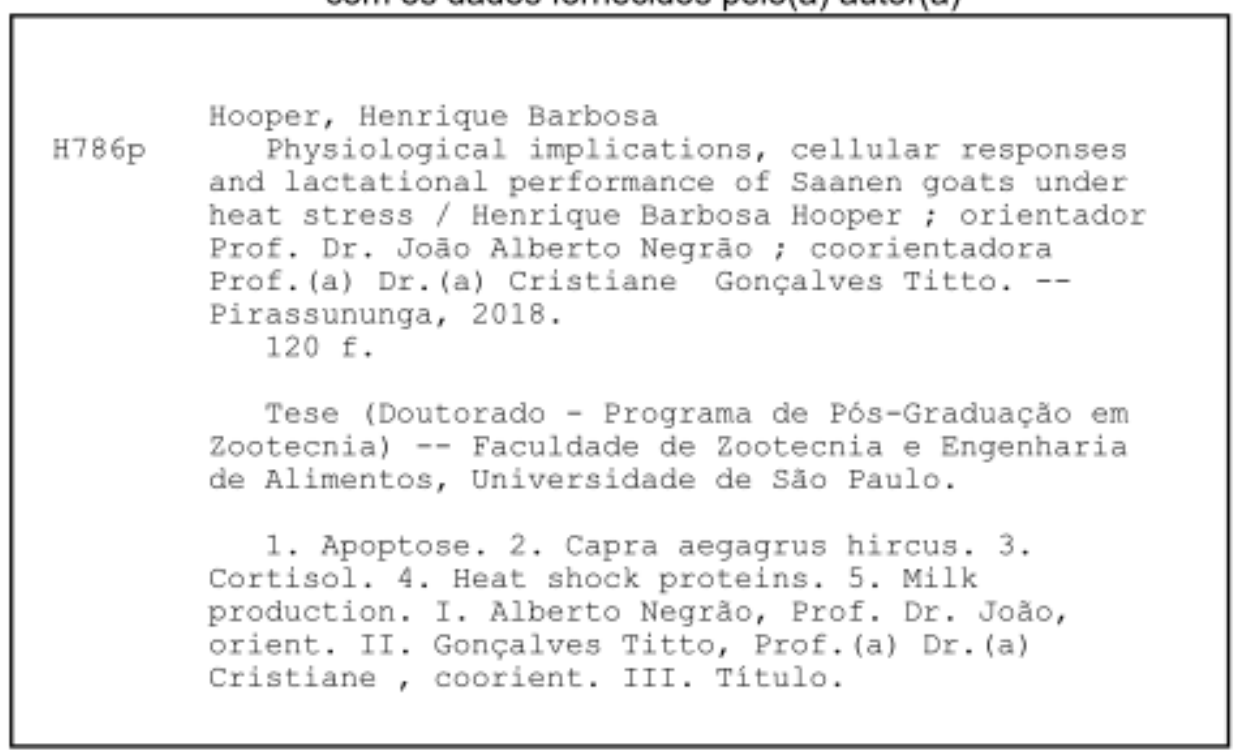

Permitida a cópia total ou parcial deste documento, desde que citada a fonte - o autor 


\section{Physiological implications, cellular responses and lactational performance of Saanen goats under heat stress}

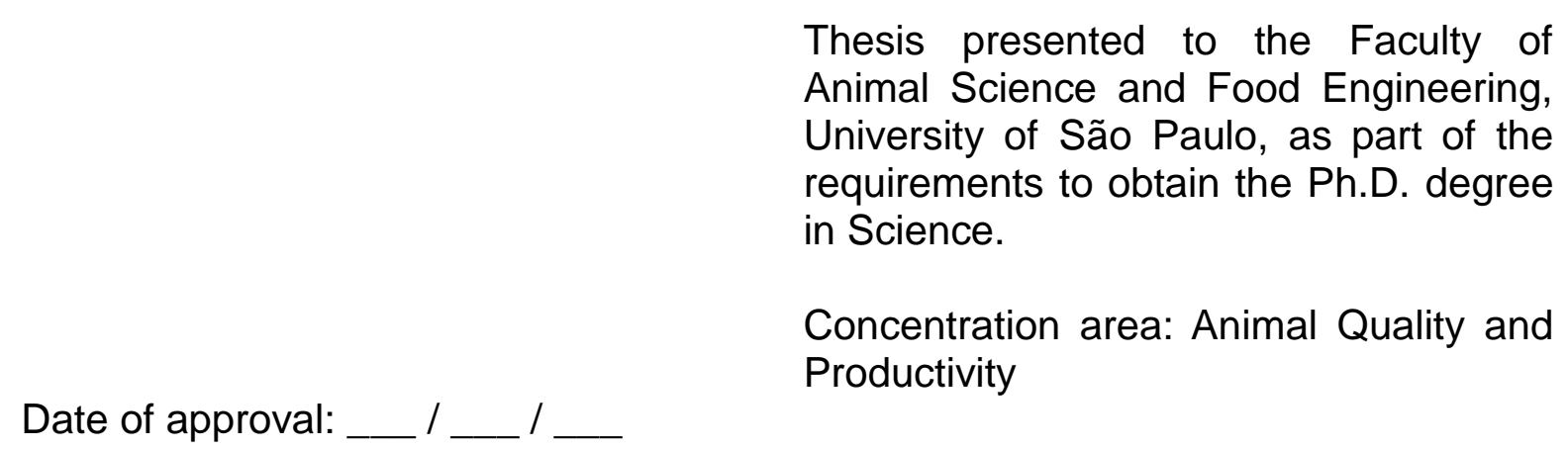

Thesis Defense Committee

Prof. Dr. João Alberto Negrão (President of the Committee) Institution: University of São Paulo

Prof. Dr. Alfredo Manuel Franco Pereira Institution: University of Évora

Prof.(a) Dr.(a) Deise Carla Almeida Leite Dellova Institution: University of São Paulo

Prof.(a) Dr.(a) Fernanda Alves de Paiva Institution: Federal Institution of Paraná

Prof.(a) Dr.(a) Mara Regina Bueno de Mattos Nascimento Institution: Federal University of Uberlândia Dr.(a) Lenira El Faro Zadra Institution: Institute of Animal Science of the State of São Paulo 
A todo àqueles que amo, família e amigos, por me apoiarem na busca do conhecimento, na construção de uma sociedade mais consciente e preocupada com a produção e o bem-estar animal. 


\section{AGRADECIMENTOS}

Primordialmente, faço meus agradecimentos à Deus e Santo Expedito, por me conduzirem sempre com determinação nos meus objetivos, me protegendo, me abrindo os olhos e guardando, para que dia após dia pudesse me fortalecer e concretizar meus ideais.

Aos meus pais, Adolfo e Denise, meu irmão, Thiago, minha fortaleza e porto seguro, pelo apoio e incentivo incondicionais.

Aos meus avós Jessi e Marcos, Matilde e Gaspar, que tanto contribuíram e contribuem na minha formação pessoal e profissional.

Aos meus tios e tias, queridos primos que mesmo à distância me apoiam.

Ao meu orientador, Prof. Dr. João Negrão, pela orientação, ensinamentos e pela oportunidade de continuar me aperfeiçoamento dentro da área da Fisiologia Animal, além da amizade e confiança creditados ao meu trabalho.

À minha co-orientadora, Prof (a). Dr (a). Cristiane Titto, por deixar sua porta sempre aberta para auxiliar em qualquer dúvida, dar sugestões e ensinar.

Ao meu supervisor de estágio sanduíche, Dr. Pierre Lacasse, grande pesquisador na área e excelente pessoa, bem como sua equipe que tanto contribuíram na minha formação em pesquisa durante minha experiência no Canadá.

A Prof (a). Dr (a). Anneliese Traldi (Kiki), por todo auxílio, cooperação e instrução dedicados durante a realização do experimento.

Aos técnicos do laboratório, Giovana, Sandra e Antônio, por todo auxílio e ajuda durante a realização do projeto e análises, pela amizade e convívio.

À amiga e parceira Priscila por toda dedicação, competência, aventuras e boas risadas que fizeram de toda essa jornada muita mais leve.

Aos demais pós-graduandos do Laboratório de Fisiologia Animal, Emanuel, Gabriela, Aska e Marta pelo trabalho de equipe e convívio.

Aos estagiários que não mediram esforços em colaborar e aprender mais durante a realização do experimento. 
Aos amigos da família Caipira, Fábio, Guilherme, Juan, Talles, Danilo, Thiago, Stephan e Douglas pela grande amizade e convivência.

Aos meus amigos pelos bons momentos e carinho.

Aos professores e colegas de pós-graduação da FZEA e da FMVZ pelos momentos no corredor do prédio, aulas e descontrações em nossas reuniões, festas e churrascos.

Aos financiamentos obtidos pela CAPES (Coordenação de Aperfeiçoamento de Pessoal de Nível Superior) e FAPESP (Fundação de Amparo à Pesquisa do Estado de São Paulo).

Ao CNPq (Conselho Nacional de Desenvolvimento Científico e Tecnológico) pela concessão e financiamento da bolsa de estudos durante todo o período de realização do Doutorado.

À Faculdade de Zootecnia e Engenharia de Alimentos por me acolher, dar suporte estrutural, de ensino e pesquisa durante a Pós-graduação. 
Agir, eis a inteligência verdadeira. Serei o que quiser. Mas tenho que querer o que for. O êxito está em ter êxito, e não em ter condições de êxito. Condições de palácio tem qualquer terra larga, mas onde estará o palácio se o não fizerem ali? 


\begin{abstract}
HOOPER, H.B. Physiological implications, cellular responses and lactational performance of Saanen goats under heat stress 2018. p. 120. Thesis (PhD) Faculty of Animal Science and Food Engineering, University of São Paulo, Pirassununga.
\end{abstract}

The exposure to heat can adversely affect animal performance and productivity, particularly when associated with pregnancy. The comprehension of the physiological and cellular responses during heat stress assists the decisions to improve the productivity of goats in a tropical environment. In this context, this study evaluated the physiological and cellular responses of Saanen goats in acute and chronic stress conditions. Healthy Saanen goats were randomly assigned to heat stress treatment, short-term, under solar radiation and in the long-term, in climatic chamber. Data were analyzed using the Statistical Analysis System (SAS). The normality was confirmed using the Shapiro-Wilk test. In acute heat stress, solar radiation caused the increase of cortisol release, respiratory rate and reduced T3 and T4 to restore homeothermia. The expression of p53 (pro-apoptotic protein), Bcl-2 (anti-apoptotic protein), HSP60, HSP70 and HSP90 was higher in leukocyte cells for heat stressed goats. In chronic heat stress at the end of gestation, goats significantly mobilized the increase of respiratory rate to lose heat, with cortisol elevation on the 15 days previous to parturition $(P<0.05)$, which was even greater at day 15 postparturition. At the cellular level, HSP70 was the most expressed during and after heat challenge, with more transcripts at day 15 postparturition for the heat stressed goats. In mammary epithelial cells, there were an increase in apoptosis-related transcripts, p53 and Bax, for the group undergoing heat stress before parturition. The expression of HSP27 was higher before and after parturition for the same group when compared to the animals in thermal neutrality. During lactation, the stressed goats presented lower milk yield. The heat challenge increased the percentage of fat and decreased lactose. The somatic cell count was higher for stressed goats during all lactation. During lactation, the gene expression of prolactin receptor (PRLr) was lower for heat stress goats, which may explain the reduction in milk production at subsequent lactation. In conclusion, our findings suggest that respiratory rate and HSP70 are reliable biomarkers for assessing the thermal comfort and thermotolerance of 
Saanen goats under acute and chronic heat stress. In addition, chronic thermal stress at final gestation impaired milk production and milk composition from subsequent lactation.

Keywords: apoptose; Capra aegagrus hircus; cortisol; heat shock proteins; milk production; 


\section{Resumo}

HOOPER, H.B. Implicações fisiológicas, respostas celulares e desempenho lactacional de cabras Saanen em estresse térmico. 2018. 120 f. Tese (Doutorado) - Faculdade de Zootecnia e Engenharia de Alimentos, Universidade de São Paulo, Pirassununga.

A exposição ao calor pode afetar negativamente o desempenho e a produtividade dos animais, particularmente quando associados à gestação. Compreender as relações entre as respostas fisiológicas e celulares, quando em estresse por calor, auxilia na tomada de decisões para melhorar a produtividade de caprinos em ambiente tropical. Neste contexto, este estudo avaliou as respostas fisiológicas e celulares de cabras Saanen em condição de estresse agudo e crônico. Cabras da raça Saanen saudáveis foram aleatoriamente expostas ao estresse por calor, de curto prazo sob radiação solar e a longo prazo em câmara climática. Os dados foram analizados utilizando o software estatístico "Statistical Analysis System" (SAS, 2008). A normalidade foi confirmada com o teste de Shapiro-Wilk. Em estresse agudo, a radiação solar promoveu o aumento da liberação de cortisol, elevou a frequência respiratória e reduziu T3 e T4, para reestabelecer a homeotermia. Observou-se nas células leucocitárias das cabras sob estresse, aumento da expressão da p53 (proteína pró-apoptótica), Bcl-2 (proteína anti-apoptótica), HSP60, HSP70 e HSP90. Sob estresse crônico no final da gestação, as cabras aumentaram a frequência respiratória para perder calor, com elevação do cortisol no dia 15 pré-parto ( $P$ $<0,05)$, que foi ainda maior no dia 15 pós-parto. A nível celular, a HSP70 foi a mais expressa durante e após o desafio com calor, com mais transcritos no dia 15 pósparto para as cabras sob estresse. Nas células epiteliais mamárias, houve aumento dos transcritos relacionados à apoptose, p53 e Bax, para o grupo sob estresse por calor antes do parto. A expressão da HSP27 foi maior antes e após o parto para o mesmo grupo quando comparado aos animais em termoneutralidade. Durante a lactação, as cabras sob estresse apresentaram menor produção de leite. O desafio de calor aumentou o percentual de gordura e diminuiu a lactose. A contagem de células somáticas foi maior para as cabras sob estresse durante toda a lactação. $A$ expressão gênica do receptor de prolactina (PRLr) foi menor para as cabras sob estresse, 15 dias após o parto, o que pode explicar a redução na produção de leite 
na lactação subsequente. Em conclusão, nossos achados sugerem que a frequência respiratória e a HSP70 são biomarcadores confiáveis para avaliar o conforto térmico e a termotolerância de cabras Saanen sob estresse por calor agudo e crônico. Além disso, o estresse por calor crônico pré-parto prejudicou a produção e a composição do leite da lactação subsequente.

Palavras-chave: apoptose; Capra aegagrus hircus; cortisol; produção de leite; proteínas de choque térmico. 


\section{SUMMARY}

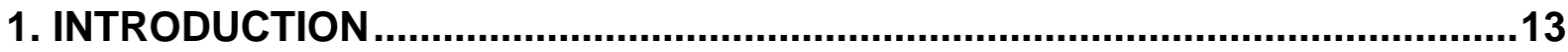

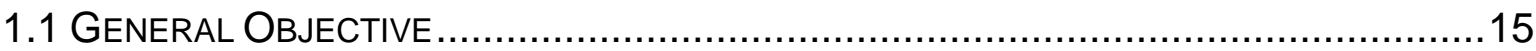

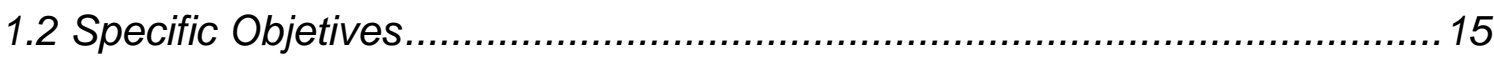

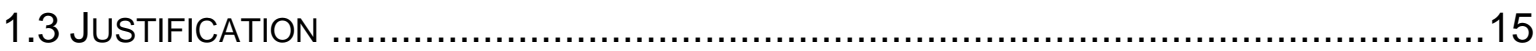

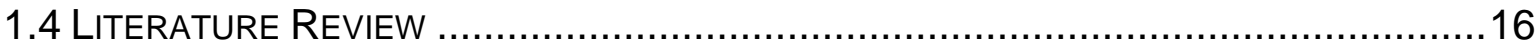

1.4.1 Environment and animal production ................................................. 16

1.4.2 Acclimatization: compensatory adjusments in natural environment ..........17

1.4.3 Thermotolerance: heat shock protein response ..................................22

1.4.4 Heat stress at final gestation: Mammary Epithelial Cells (MEC) turnover 25

REFERENCES .......................................................................................... 29

2. ACUTE HEAT STRESS INDUCES CHANGES IN PHYSIOLOGICAL AND CELLULAR RESPONSES IN SAANEN GOATS ..................................................36

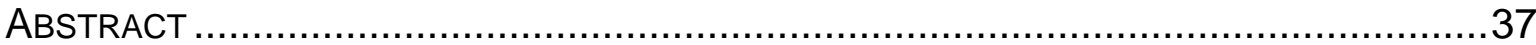

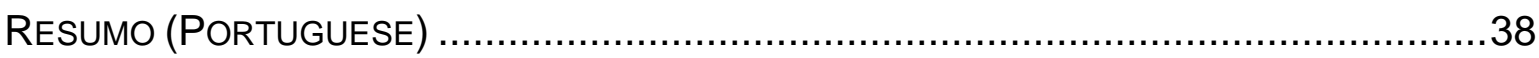

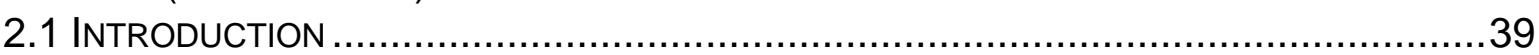

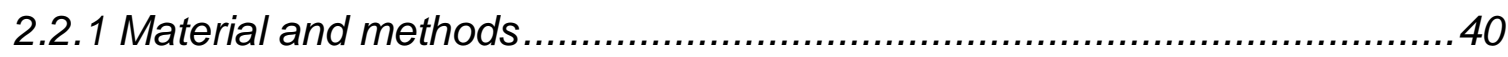

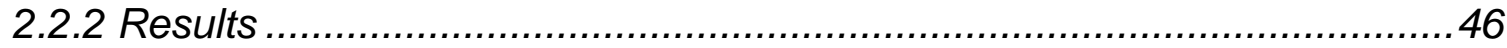

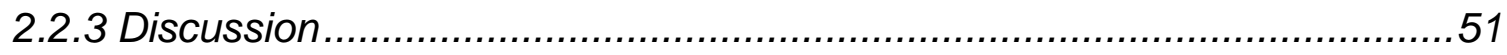

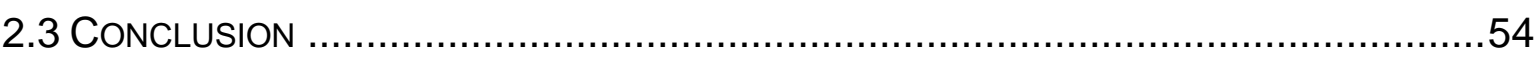

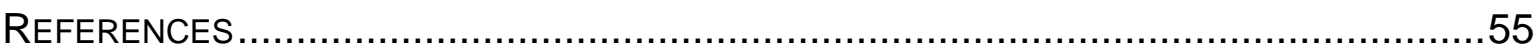

3. PHYSIOLOGICAL AND HEAT SHOCK RESPONSES OF SAANEN GOATS DURING AND AFTER LONG-TERM HEAT STRESS AT FINAL GESTATION.......60

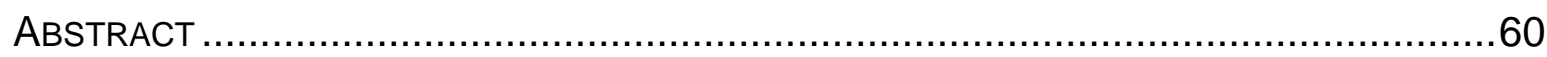

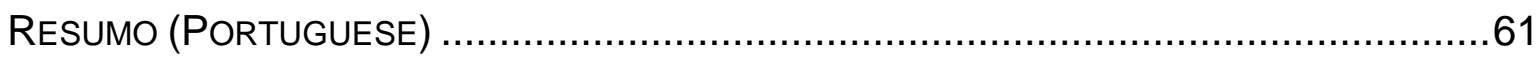

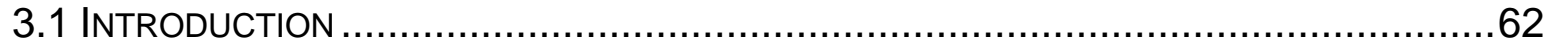

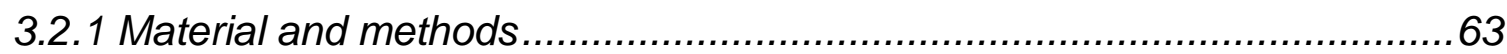

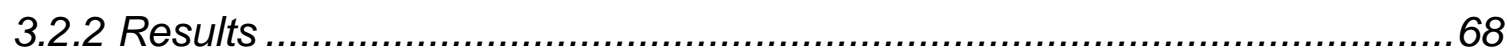

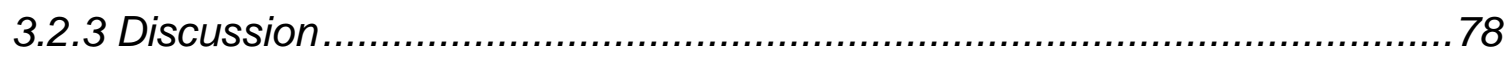

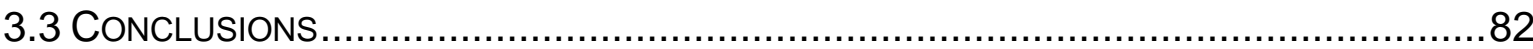

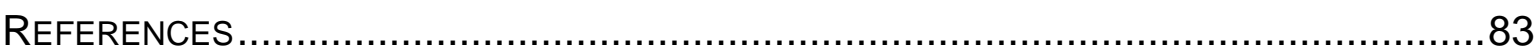

4. HEAT STRESS AT FINAL GESTATION OF SAANEN GOATS: LACTATION PERFORMANCE AND MAMMARY CELLULAR RESPONSES ............................88

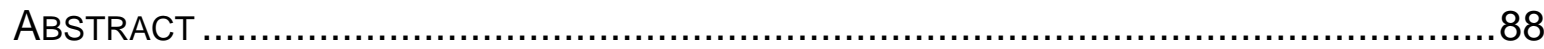

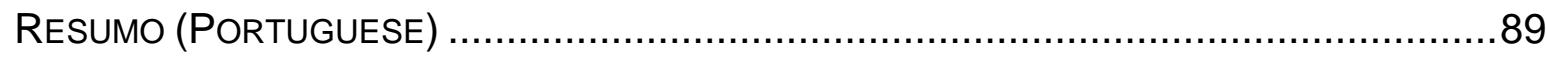

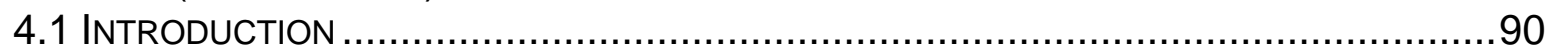

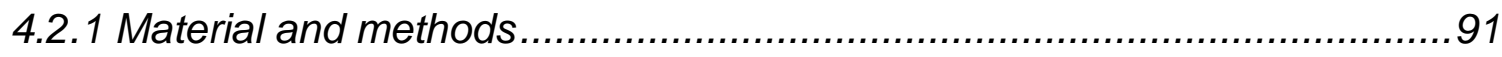

4.2.2 Results ........................................................................................... 96

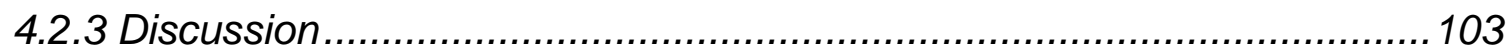

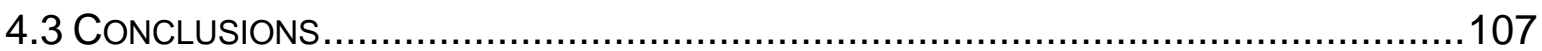

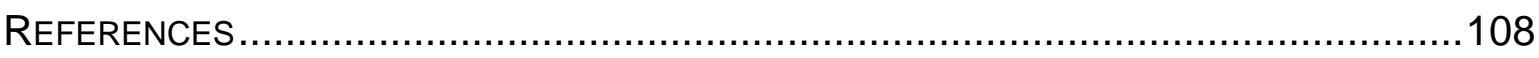

ADDENDUM 


\section{INTRODUCTION}

Humanity has been living climatic events with changes on seasonal regularity, whether by long periods of drought, the occurrence of heavy storms, intense solar radiation, cyclones, floods, among others. These events not only disorder the urban site but negatively impact the countryside. In livestock productions, climatic changes disrupt performance, weight gain, milk production, breeding and disease incidence of animals. In extensive systems, pronounced effects on animals of climate change is expected because they are directly exposed to higher thermal load.

The association of climatic variables (air temperature, relative humidity, radiation and wind) promotes physiological and behavioral changes, such as the increase on deep and superficial temperatures, respiratory rate, reduction in feed intake, blood flow redistribution, depression of the immune system and changes in endocrine functions, that affects the productive and reproductive performance (LU, 1989).

The adaptation is a result of the combined mobilization of physiological, hormonal, behavioral and cellular mechanisms. Goats, compared to other ruminants, have good adaptability, due to their low metabolic requirement and body weight, ability to lose heat and better water balance (SILANIKOVE, 2000b). On the other hand, even with these characteristics, some breeds, are challenged by thermal environment. In order to maintain thermal equilibrium, small ruminants require latent mechanisms to lose heat with the increase of respiratory and sweating rates. It causes a greater water consumption and evaporation. Moreover, there are changes on the metabolic rate, with the reduction of T3 and T4, accompanied by variation in ingestive behavior and physiological parameters.

At cellular level, the maintenance of functions under normal and adverse conditions occurs through protective mechanisms, named heat shock proteins (HSPs), important in the processes of cell renewal and death. Therefore, under heat stress, cellular proteins lose their natural conformation and functions. In these cases, the HSPs are recruited to stabilize such disorders. Otherwise, heat stress can trigger cell death factors, elevate apoptosis rate, influence hepatic metabolism, immune 
function and indirectly milk production (TAO et al., 2011; WOLFENSON; FLAMENBAUM; BERMAN, 1988).

At final gestation, the mammary gland needs to be re-established to start a new lactation, with involution, hormonal lactation induction and high cell turnover, (ADIN et al., 2009; CAPUCO; AKERS; SMITH, 1997). Additionally, mother reduces the dry matter intake and the fetus grow fast. Therefore, welfare is a key point to animals at final gestation, in which they are exposed to stressors, such as heat stress. However, slight comfort is provided to animals during this moment that impairs milk production on subsequent lactation. 


\subsection{General Objective}

The objective of this study was to determine the effects of short and long term heat stress on the physiological and cellular responses of Saanen goats.

\subsection{Specific Objetives}

a) To investigate the effects of short-term heat stress caused by the exposure to solar radiation on physiological, hormonal and gene expression responses in polymorph nucleated cell of non-pregnant Saanen goats.

b) To evaluate the effects of long-term heat stress at final gestation on the physiological, hormonal responses, and gene expression in polymorph nucleated cells of Saanen goats.

c) To study the effects of long-term heat stress at final gestation on milk production, composition and gene expression responses in mammary epithelial cell of Saanen goats.

\subsection{Justification}

It is expected to recognize the physiological and cellular responses of Saanen goats under acute and chronic heat stress when the stress occurs during the final gestation, taking in account the necessity to provide welfare at this phase. In this way, it will be possible to understand the mechanisms recruited in these circumstances and which are consequences on the lactation performance in subsequent lactation. 


\subsection{Literature Review}

\subsubsection{Environment and animal production}

In the coming decades, it is expected an increase on animal production to supply food demand. At the same time, the occurrence of unfavorable weather events will impact agriculture and livestock systems. These climatic changes will directly and indirectly influence animals by reducing dry matter intake, milk production, reproductive performance, the frequency, intensity and distribution of diseases, among others (NARDONE et al., 2010; SILANIKOVE; KOLUMAN, 2015). Thus, it will be necessary an advanced planning in livestock, in which the responses of animals during heat, the ability to dissipate it, and how to prevent the adverse consequences are known and under control (NIENABER; HAHN, 2007).

Goat, sheep, buffalo and camel dairy systems are important in specific regions, especially those based on familiar production in developing countries, such as India and Africa (NARDONE et al., 2010). In developing countries, goat had fast and continuous raise, demonstrating their better adaptability even in harsh environmental conditions (extreme of temperatures, lack of food and different altitudes). Besides, in developed countries, goats also gained visibility with the increase in milk production and improved performance of animals (BOYAZOGLU; HATZIMINAOGLOU; MORAND-FEHR, 2005).

Even with good adaptability characteristics dairy goats reduce performance when heat challenged. Saanen goats exposed to moderate or severe heat stress during lactation for four days (Temperature and Humidity Index; $\mathrm{THI}=81$ or 89 ), reduced milk production from $3 \%$ to $13 \%$ (SANO; AMBO; TSUDA, 1985). A reduction of $6 \%$ in milk production was observed in Alpine goats, as well as in the percentages of fat, protein, lactose and total solids (BRASIL et al., 2000). According to the same authors, heat stress caused weight lost, reduction in dry matter intake, increase of water consumption, respiratory and sweating rates. Alpine goats when exposed to moderate heat stress for 5 weeks $\left(34^{\circ} \mathrm{C}\right.$ of air temperature, $25 \%$ of relative humidity and 79 of THI) had reduced milk yield (BROWN; MORRISON; BRADFORD, 1988). Otherwise, that was not observed for Anglo-Nubian goats, which holds better 
adaptation to heat when compared to other goat breeds (BROWN; MORRISON; BRADFORD, 1988).

Milk production decreases for dairy goats as the THI increases, with a reduction of $1 \%$ in milk production per unit of increase in THI (SALAMA et al., 2014) (Table 1). The same authors reported that goats under heat stress reduced feed intake, increased energy requirements for maintenance, breathing and sweating rate, and synthesizes heat shock proteins (HSPs). Comparatively, in Holstein cows a reduction of $10 \%$ in milk yield between summer and winter was observed, besides the protein percentages were altered (BERNABUCCI et al., 2015). In another study with cows, when THI exceeded 72 the milk protein values decreased, whereas the fat levels the results are contradictory (BERNABUCCI; CALAMARI, 1998). Similar to dairy cattle, dairy goats positively respond to cooling with a reduction on respiratory rate (from 70 to 22 respiratory movements per minute), rectal temperature (0.2 to $1.7^{\circ} \mathrm{C}$ ) and increased milk production (DARCAN; GÜNEY, 2008).

Table 1: Comparison between the heat stress risk for dairy cows and goats according to the Temperature and Humidity Index (THI).

\begin{tabular}{lcc}
\hline \multicolumn{1}{c}{ Heat stress classification } & Dairy Cows & Dairy Goats \\
\hline Normal: no effect on milk production & $\mathrm{THI}<74$ & $\mathrm{THI}<80$ \\
Alert: moderate effects on milk production & $74 \leq \mathrm{THI}<79$ & $80 \leq \mathrm{THI}<85$ \\
Danger: severe effects on milk production & $79 \leq \mathrm{THI}<84$ & $85 \leq \mathrm{THI}<90$ \\
Extreme: can lead to death & $\mathrm{THI} \geq 84$ & $\mathrm{THI} \geq 90$ \\
\hline
\end{tabular}

(Source: Adapted from SILANIKOVE, N.; KOLUMAN, D. N. Impact of climate change on the dairy industry in temperate zones: Predications on the overall negative impact and on the positive role of dairy goats in adaptation to earth warming. Small Ruminant Research, v. 123, n. 1, p. 27-34, 2015).

\subsubsection{Acclimatization: compensatory adjusments in natural environment}

Body temperature regulation is controlled by a hierarchy of neural structures, in spine and brainstem (BOULANT, 2000). In the anterior hypothalamus, the preoptic region acts as a thermosensitive coordinator center receiving stimuli from the skin and spinal thermal-receptors (BOULANT, 2000). In this way, the pre-optic region integrates and compares the central and peripheral thermal information. In addition to 
neural functions, the hypothalamus exerts important endocrine role related to thermoregulation (AFSAL et al., 2018). The hormones most related to thermoregulation process are the corticotrophin releasing hormone $(\mathrm{CRH})$, adrenocorticotrophic hormone (ACTH), glucocorticoids, thyrotropin releasing hormone $(\mathrm{TRH})$, thyroid stimulating hormone $(\mathrm{TSH})$, thyroid hormones and prolactin (AFSAL et al., 2018). As well as, the neurotransmitters epinephrine and norepinephrine, the hormones leptin and aldosterone. Among the mechanisms of heat transfer between the animal and environment there are: the conduction, convection, radiation, evaporation, related to vasoconstriction or vasodilatation, increase on respiratory rate and sweating, cutaneous perspiration, piloerection and variation on feed behavior (LU, 1989) (Figure 1).

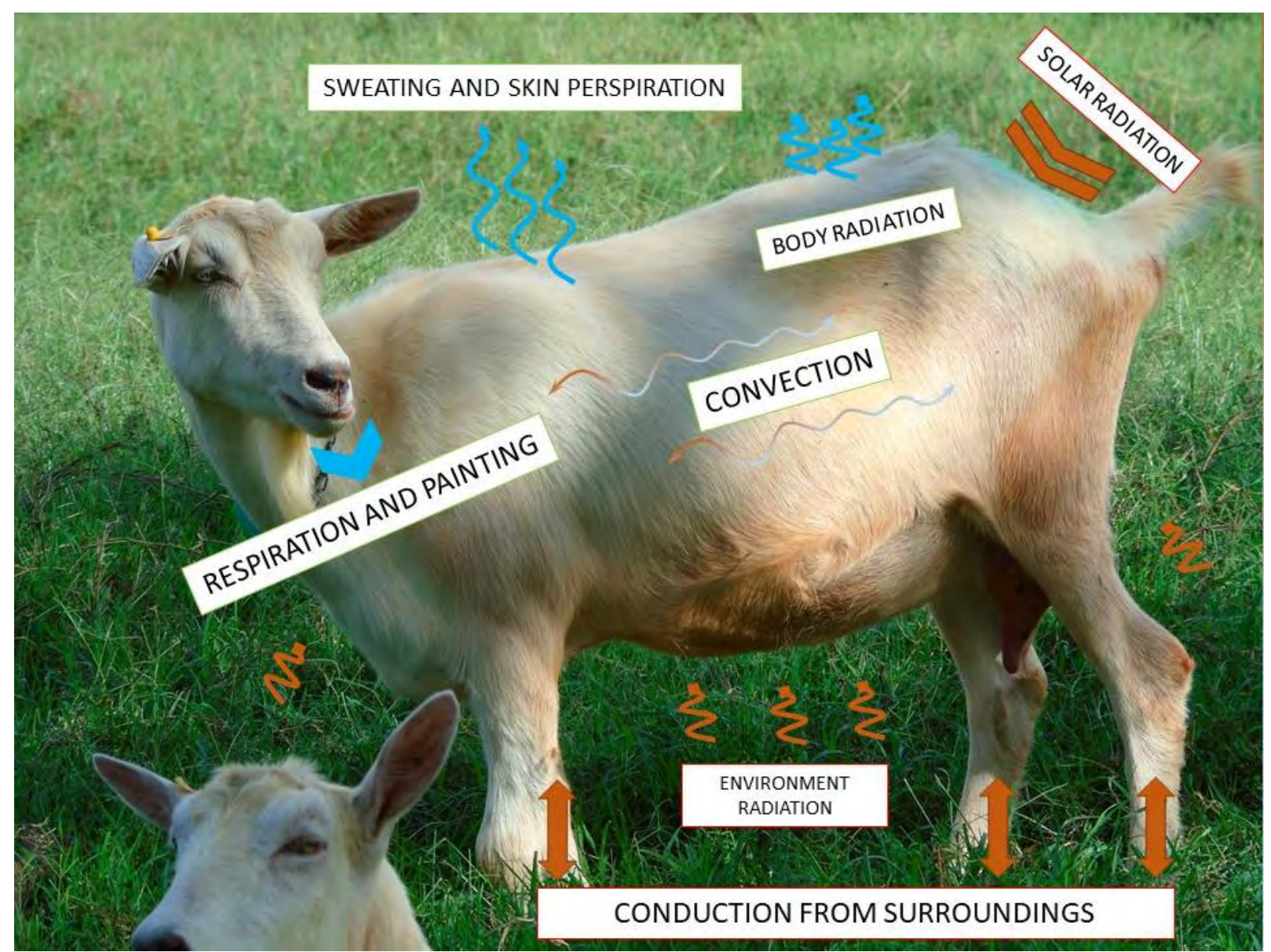

Figure 1. Mechanisms of heat exchange between the organism and the environment by radiation, conduction, convection and evaporation. Source: Own Authorship

As homeothermic animals, goats can maintain the body core temperature within certain limits, regarding of the environment temperature in which they are 
exposed (CABANAC, 1975; HAMMEL; PIERCE, 1968). The Thermal Comfort Zone (TCZ) is the temperature range that little efforts are necessary to regulate the body core temperature, when the animals are in comfort and reach their maximum productive potential (Figure 2). Beyond this limit, more energy to control body temperature is demanded, therefore, mechanisms of heat lost and gain are recruited, affecting productive performance, threatening survival (KERR, 2015).

The set of behavioral and physiological changes promoted by physical stressors (cold, heat, hunger, thirst, deprivation of space), social or management practices characterize the stress condition (GRANDIN, 2000). The behavior and physiological parameter monitoring is a practice that determines if the animals are in stress condition. Heat stress occurs when the environmental variables exceed the upper critical limit of the thermal neutral zone, resulting in a total heat load (internal and environmental) that exceeds the capacity of dissipation (BERNABUCCI et al., 2010). Under heat stress animals increase the rectal temperature, respiratory frequency, heart rate and cortisol release (MAIA et al., 2015). Other signs include the decrease of appetite, the increase of water consumption, agglomeration in water droughts and shaded areas, painting, immobility, sialorrhea, and in cases of thermal shock with collapse, lower reactivity to surroundings, seizure and death (KERR, 2015).

Stress also endorses failures in the expression of genetic potential caused by the inability to adjust to the environment (DOBSON; SMITH, 2000). Animals respond to stress according to the type of challenge: in acute events, behavioral short-term adaptive responses, physiological responses and immunological functions take place; but in long-term events the responses are oriented to performance, survival, growth, and reproduction (NIENABER; HAHN, 2007).

The capacity to adjust in face of a set of environmental conditions, even at climatic extremes is known as adaptation (McMANUS et al., 2009). It can also be considered as the ability to deal with climate change through the expression of adaptive strategies (SILANIKOVE, 2000b). According to the same authors, the process of adaptation is divided in ingestive, metabolic, physiological and morphological. 


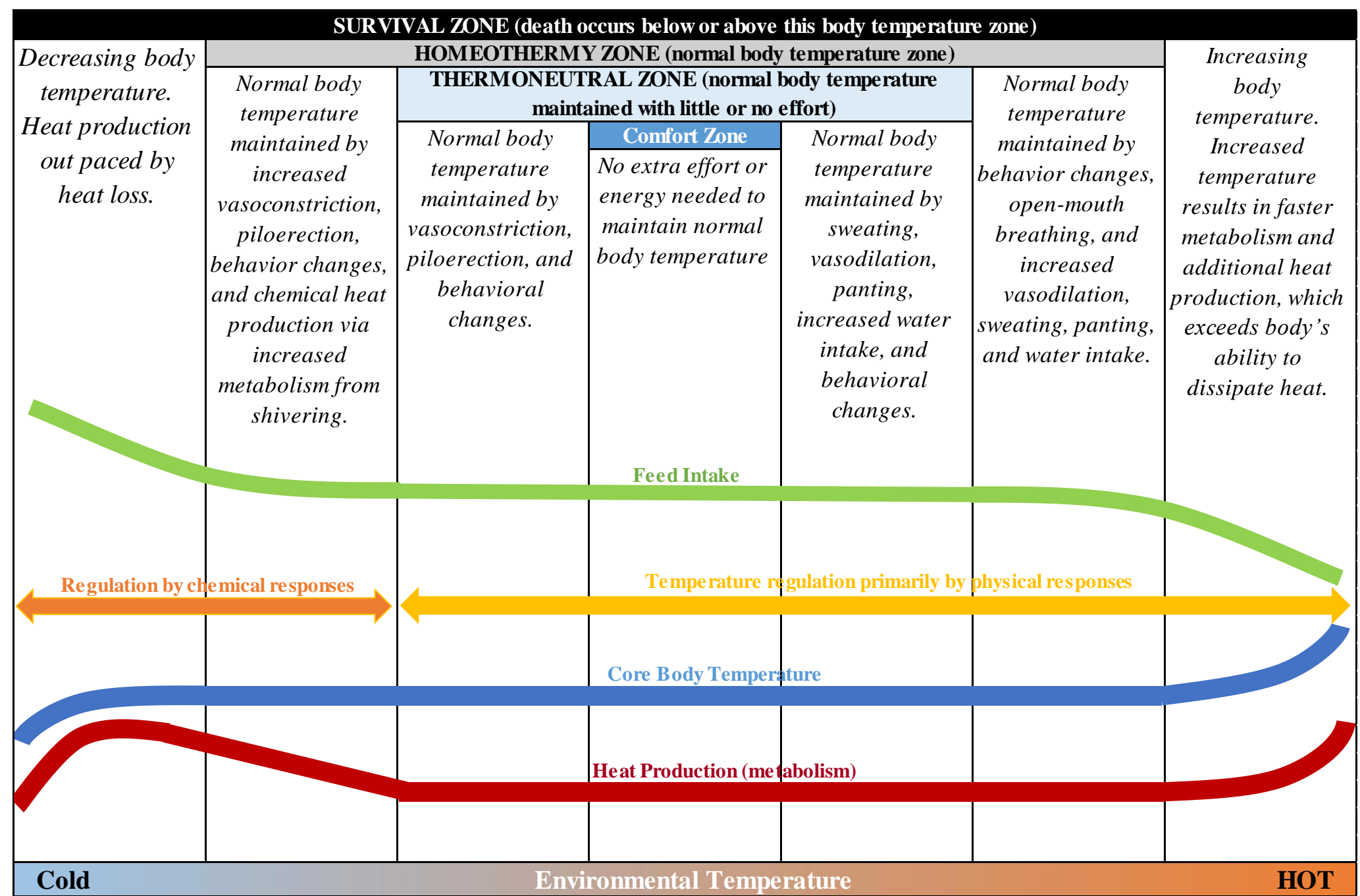

Figure 2. Mechanisms of body temperature control in mammals in response to changes in ambient temperature. Source: Adapted from KERR (2015) 
The adaptation to heat is divided in acclimatization and thermotolerance. Acclimatization is the ability to perform work, even under stress caused by moderate and repeated elevation of temperature, by the improvement in heat dissipation (MOSELEY, 1997). It allows the increase of heat transfer to skin and capacity to tolerate higher temperatures (MOSELEY, 1997). Heat acclimatization immediately begins after its exposure, being a transient event, with the increase of autonomic activity and molecular mechanisms of protection, whereas in the long-term exposition there are modulation of genes and cellular responses (HOROWITZ, 2002). According to the same author, the heat shock response is a fast process, associated with heat shock proteins synthesis (HSPs) to protect cells from the noxious stimulus and accelerate reparation after short and sub-lethal thermal injury.

In goats, the rectal temperature is maintained within $38.5^{\circ} \mathrm{C}$ and $39.7^{\circ} \mathrm{C}$ (SILVA, 2000). The monitoring of rectal temperature is a good indicator of the animal welfare, when exposed to a stressful conditions and also to understand adaptation process (SILANIKOVE, 2000a). In an experiment conducted with MurcianoGranadina dairy goats at the end of lactation, kept under thermal stress in a climatic chamber $\left(37^{\circ} \mathrm{C}\right.$ during the day and $30.5^{\circ} \mathrm{C}$ at night, $40 \%$ humidity and constant photoperiod) there was an increase of rectal temperature $\left(+/-0.58^{\circ} \mathrm{C}\right)$, respiratory rate (+48 respiratory movements/minute), ingestion $(+77 \%)$ and water evaporation (+207\%) (HAMZAOUI et al., 2013). Similar physiological reactions were found in other goat breeds subjected to heat stress in a climatic chamber at $40^{\circ} \mathrm{C}$ for 4 hours (BIANCA; KUNZ, 1978).

Goats are under heat stress when the air temperature exceeds the upper critical limit, from $25^{\circ} \mathrm{C}$ and $30^{\circ} \mathrm{C}$ (LU, 1989). Thus, the mechanisms used for thermoregulation are mobilized according to the changes on thermal environment (MAIA et al., 2016). The same authors noted that Anglo-Nubian goats hadn't mobilized latent mechanisms when the air temperature was between $22^{\circ} \mathrm{C}$ and $26^{\circ} \mathrm{C}$, however, they mostly lost heat by convection and long wave radiation. Although, when the air temperature exceeds $30^{\circ} \mathrm{C}$ the Anglo-Nubian goats mainly recruited the evaporative mechanisms to lose heat. Thus, the authors concluded that for this breed the upper critical limit was above $26^{\circ} \mathrm{C}$. 
Thermal stress affected the thermoregulation of Aardi goats, higher rectal, vaginal, skin, superficial temperatures and cortisol concentrations were observed in summer than in winter, otherwise T3 and T4 were lower (AL-SAMAWI; AL-HASSAN; SWELUM, 2014). In a study conducted in Italy, Garfagnina goats had higher values of rectal and skin temperatures, respiratory and heart rate in the afternoon in spring and summer, and T3 and T4 was lower in summer (RIBEIRO et al., 2016). Alpine goats subjected to thermal stress $(\mathrm{THI}=86.20)$ showed differences in rectal temperature, but no variations in T3, T4, cortisol concentration and lipid metabolites compared to the control group (URIBE-VELASQUEZ et al., 1998).

Alpine goats under heat stress in climatic chamber for 56 days $(\mathrm{THI}=86.47)$, presented higher respiratory rate, rectal temperature and sweating rate, as well as reduction of respiratory tidal volume and mean of globular volume (BRASIL et al., 2000). On the other hand, in the same study, the authors observed a reduction in milk production $(1.02 \mathrm{~kg}$ for the thermal neutrality vs. $0.96 \mathrm{~kg}$ for the heat stress group) and fat, protein, lactose and total solids percentages of dairy animals maintained in thermal stress.

Murcian-Granadine goats under stress $\left(30.5^{\circ} \mathrm{C}\right.$ to $\left.37^{\circ} \mathrm{C}\right)$, compared to thermal neutrality $\left(15\right.$ to $\left.20^{\circ} \mathrm{C}\right)$, did not change the milk yield, however, had reducted $12.5 \%$ on milk protein and $11.5 \%$ of casein were observed (HAMZAOUI et al., 2013). For the authors, goats were able to maintain milk production by recruiting body reserves. The adaptation on these animals was observed by the physiological parameters, with the increase of rectal temperature and respiratory rate in the first week of heat stress, which gradual decrease in the following weeks.

\subsubsection{Thermotolerance: heat shock protein response}

In 1962, the scientist Ritossa exposed salivary glands of Drosophila melanogaster to heat at $37^{\circ} \mathrm{C}$ and at $25^{\circ} \mathrm{C}$, and he observed the occurrence of a chromosomal alteration. This discovery was the first gene encoding of HSPs was registered. Since then, several researches have been taken about the role of HSPS during stress condition. Later, it was named as thermotolerance and defined as the 
cellular adaptation caused by a single, severe but non-lethal heat exposure, that allows the body to survive subsequent and lethal heat stress, by the cellular synthesis and accumulation of HSPs (MOSELEY, 1997).

Under heat stress, cells inhibit DNA synthesis, RNA processing, transcription, translation, cell cycle progression, the cytoskeletal elements are ruptured, proteins are denaturated and membrane permeability is changed (BERNABUCCI et al., 2010; KERR, 2015). Against these process, defense mechanisms to contain such imbalances are activated, among them the chaperone molecules named as HSPs (MACARIO; MACARIO, 2007). They are classified according to the molecular weight being inside cytosol, mitochondria, endoplasmic reticulum and nucleus (KREGEL, 2002; SØRENSEN; KRISTENSEN; LOESCHCKE, 2003).

The regulation of HSPs occurs with the participation of transcriptional heat shock factors (HSFs) and heat shock elements (HSEs) (KIANG; TSOKOS, 1998). In normal conditions, HSPs are bound to HSFs in the cytosol, but with the de novo synthesis, HSPs separate from it, they are phosphorylated by protein kinase $C$ (PKC) or another serine-threonine kinase protein and grouped as a homo-trimeric structure. The trimer migrates to the nucleus and bind to the HSEs. Thus, the transcription begins and the translation of new HSPs. The new HSPs when associated with the HSFs in the cytosol prevent new synthesis.

In mammals, the most studied HSPs are the molecular weight 27, 60, 70, 90 and $110 \mathrm{kDa}$, being expressed under normothermia conditions and are more expressed when the cells are challenged either by hyperthermia, energetic depletion, hypoxia, acidosis, ischemia, reactive oxygen or nitrogen species, and infections (KREGEL, 2002). The genes involved in the synthesis of HSPs are regulated by a series of physiological processes not associated with cell stress, and they are involved in the proliferation and differentiation cycles (MILARSKI; MORIMOTO, 1986). They modulate many conditions that lead to apoptosis and with pathogenic stages (GARRIDO et al., 2001).

In many organisms, HSP70 is considered as the largest family of proteins and can be exclusively induced, constitutive and induced, or solely constitutive (SØRENSEN; KRISTENSEN; LOESCHCKE, 2003). HSP70 and HSP60 perform the 
protein movement throughout the mitochondrial membrane, while the HSP70 also participates in protein folding and membrane insertion (MOSELEY, 1997). The HSP60 acts in the protein refolding within the mitochondria (DESHAIES et al., 1988), being pro and anti-apoptotic (KREGEL, 2002). HSP90 has been associated with several cytosolic and nuclear proteins involved in cell signaling to steroid hormone receptors (BOHEN; YAMAMOTO, 1994). HSP27 has the function to prevent protein aggregation by stabilizing polymerizations (EHRNSPERGER et al., 1997).

Cells exposed to acute and chronic stressors endorse proteins disruption and chaperones restructure them, preventing loss of function and the formation of aggregates in an adaptation process. Although, there is little knowledge of the thermotolerance in goats, some authors studied the cellular responses under stressors with different intensities and durations (DANGI et al., 2012; MOHANARAO et al., 2014; ROUT; KAUSHIK; RAMACHANDRAN, 2016).

In Barbari and Pashmina goats, greater HSP60 and HSP90 expression in PBMCs was observed in summer than in winter for both breeds (DANGI et al., 2012). The gene expression profile of HSP70 was different among Indian breeds (Jamunapari, Barbari, Jakhrana and Sirohi), the Sirohi presented the highest gene expression of this gene, followed by Barbari breed. It evidences different thermotolerance profiles according to the breed in the same thermal environment (ROUT; KAUSHIK; RAMACHANDRAN, 2016).

Barbari goats when exposed to heat in a climatic chamber $\left(41^{\circ} \mathrm{C}\right.$ and $\left.45^{\circ} \mathrm{C}\right)$ increased the expression of HSP60, HSP70 and HSP90 after one hour of exposure, with a peak in gene expression of HSP105 and HSP110 after 6 hours, remaining indifferent within the first 4 hours (DANGl et al., 2014). In vitro, leukocytes initially increased the expression of HSP60, HSP70, HSP90, after heat challenge at $42^{\circ} \mathrm{C}$ for 6 hours while HSP105 and HSP110 were expressed later (DANGI et al., 2015). They observed that antioxidants administration had reduced the expression of HSPs, by the lowering the oxidative stress.

Mohanarao et al. (2014) challenged PBMCs of goat kids in vitro at $10^{\circ} \mathrm{C}$ and $42^{\circ} \mathrm{C}$ for three hours, and they found a greater expression of HSP27, both by the cold and heat stress, indicating it as a good indicator of thermal stress. HSP70 had the highest expression at $42^{\circ} \mathrm{C}$. In thermal, nutritional and combined stresses, 
Osmanabadi goats had higher plasma concentrations and gene expression of HSP70 in PBMCs when the stressors are combined, demonstrating the adaptive capacity of these animals are related to the severity of the applied stressor (SHILJA et al., 2016).

\subsubsection{Heat stress at final gestation: Mammary Epithelial Cells (MEC) turnover}

At the end of gestation occurs the allometric growth of the mammary gland, that in goats is around 70 and 80 days of gestation and reflects the increase in the division and volume of mammary epithelial cells (ROWSON et al., 2012). In sheep, the highest proliferation rate of these cells occur for around 115 days of gestation and is associated with increased cell size, elevated lactose synthesis and RNA:DNA ratio (SMITH et al., 1989; SWANSON; POFFENBARGER, 1979). Mammogenesis is regulated by placental hormones with a positive relation between the number of fetus and the production of milk in goats and sheep. This is due to the placental lactogen hormone whose plasma peak takes place on day 140 of gestation (FORSYTH, 1986).

Concomitantly, at pre-partum, dairy animals are dried to start a new lactation. The dry period is an important phase because the damaged or senescent mammary epithelial cells are replaced and epithelial components raise before starting the next lactation (CAPUCO; AKERS; SMITH, 1997). Thus, during the final gestation changes take place because of the rapid fetal growth, mammary involution of the previous lactation, cell renewal, extensive glandular growth, and endocrine induction of lactation (ADIN et al., 2009).

The cell proliferation and apoptosis rates changes at the end of gestation and onset of lactation (NØRGAARD et al., 2008). These authors noticed an increase on cell proliferation 16 days before parturition, whereas cell death was higher 48 days before and 14 days after it. The ratio of RNAm between $\mathrm{Bcl}-2 / \mathrm{Bax}$ was higher at the end of gestation, with higher proliferation of mammary cells and lower apoptosis (NØRGAARD et al., 2008). Hence, changes in the intrinsic pathway of apoptosis may be relevant for maintenance of cell numbers, but little is known about the effects on subsequent lactation. 
In mammary epithelial cells, the cell death is mainly mediated by apoptosis (ZARZYNSKA; MOTYL, 2008). Apoptosis can be initiated by the intrinsic and extrinsic pathway (Figure 3) (DURAIRAJANAYAGAM; AGARWAL; ONG, 2015; NØRGAARD et al., 2008). In the extrinsic pathway, FasL binds to its Fas membrane receptor after a stressor stimulus, which leads to recruitment of FADD (Fas domain associated with Fas). When the Fas-FasL complex is formed there is the activation of caspases 8 or 10 that activate other caspases, 3, 5 and 7. In the intrinsic pathway, mitochondrial mediated, Bax (Bcl-2 associated $\mathrm{X}$ ) is associated with Bcl-2 (B-cell lymphoma 2) to prevent mitochondria membrane disruption. However, when Bcl-2 is phosphorylated it becomes inactivated and Bax create pores in the mitochondria membrane facilitating the Cytochrome $c$ release. Cytochrome $c$ interacts with Apaf-1 (factor 1 activator of the apoptotic protease) to form a complex. Apaf-1 binds to caspase 9 by activating the caspase chain 3, 5 and 7 . These caspases (cysteineaspartic-acid-proteases) activate their substrates, initiating the cleavage of other proteins and DNA.

The nuclear protein of tumor suppression (p53) is involved in both intrinsic and extrinsic cell death pathways (DURAIRAJANAYAGAM; AGARWAL; ONG, 2015). During apoptosis, p53 is rearranged from the nuclear membrane into the nucleus where it binds to the DNA, leading to apoptosis. Usually, p53 is associated when damage occur in DNA, but it is also related to stress. Physiologically, it is involved in the regulation of the apoptosis of mammary cells under stress or even during the involution process (GREEN; STREULI, 2004).

Different than the physiological state, under heat stress the mammary cells dynamics is changed. Studies with heat stress during the last two months before calving suggest a reduction in MEC cell proliferation and milk production at subsequent lactation (TAO; DAHL, 2013). Cows in thermal comfort, cooled by fans and sprinklers had greater cellular proliferation 20 days before calving and during the transition period, than cows without cooling, which contributed to a higher milk production (TAO et al., 2011). According to the same authors, no difference in apoptosis rate was found in epithelial cells and in total cells between heat treatments. These data reveal that thermal stress during the dry period affects the growth of MEC, that reduces milk production at subsequent lactation. However, the knowledge about mammary epithelial cells growth and development during thermal stress is still 
limited, especially for dairy goats. The effects of hyperthermia on bovine MEC exposed at $40^{\circ} \mathrm{C}$ for 1 hour was studied by Du et al. (2008). They found that thermal stress promoted a significant reduction in cell viability accompanied by apoptosis, lower Bcl-2/Bax ratio and reduced mitochondrial membrane potential. Thus, hyperthermia induced apoptosis of MEC, by mean of intrinsic mechanisms of cell death.

During the apoptosis process, HSPs act in different parts of the death signaling, and may be anti-apoptotic or pro-apoptotic (GARRIDO et al., 2001). According to the same authors, among the HSPs, HSP27 and HSP70 are the ones that are greater expressed under stress or tumorigenesis of MEC. HSP27 is classified as small HSP and participates as an anti-apoptotic protein. It prevents activation of caspases 3 and 9 in addition to interacting with cytochrome $c$ and preventing the interaction with Apaf-1 and apoptosomal formation. The HSP70 is classified as anti-apoptotic by regulating various processes within the caspase cascade. MEC heat stressed in vitro $\left(42^{\circ} \mathrm{C}\right)$, presented a higher expression of HSP70 when compared to the control group $\left(38^{\circ} \mathrm{C}\right)$ ( $\mathrm{HU}$ et al., 2016b). The same authors found reduction in the expression of genes related to protein synthesis of $\beta$-casein and butyrofilin milk. These results suggest the direct effect of heat stress on MEC, with a reduction in the synthesis milk proteins.

The reduction of milk production at subsequent lactation is also related to prolactin signaling because this hormone is crucial for the complete differentiation of mammary epithelial cells close to delivery (AKERS et al., 1981), moreover it is considered anti-apoptotic (ACCORSI et al., 2002). Heat stress promotes the elevation of plasma prolactin levels, suggesting changes in lactogenesis in the final third of gestation (Do AMARAL et al., 2009, 2011). The higher photoperiod, during the dry period, increases of prolactin release, reduced the expression of the long isoform receptor and milk yield (AUCHTUNG et al., 2005). Taking that in account, more studies are needed to better investigate the effects of heat stress previous to parturition on prolactin signaling, to explain the reduction in productive performance at subsequent lactation. 


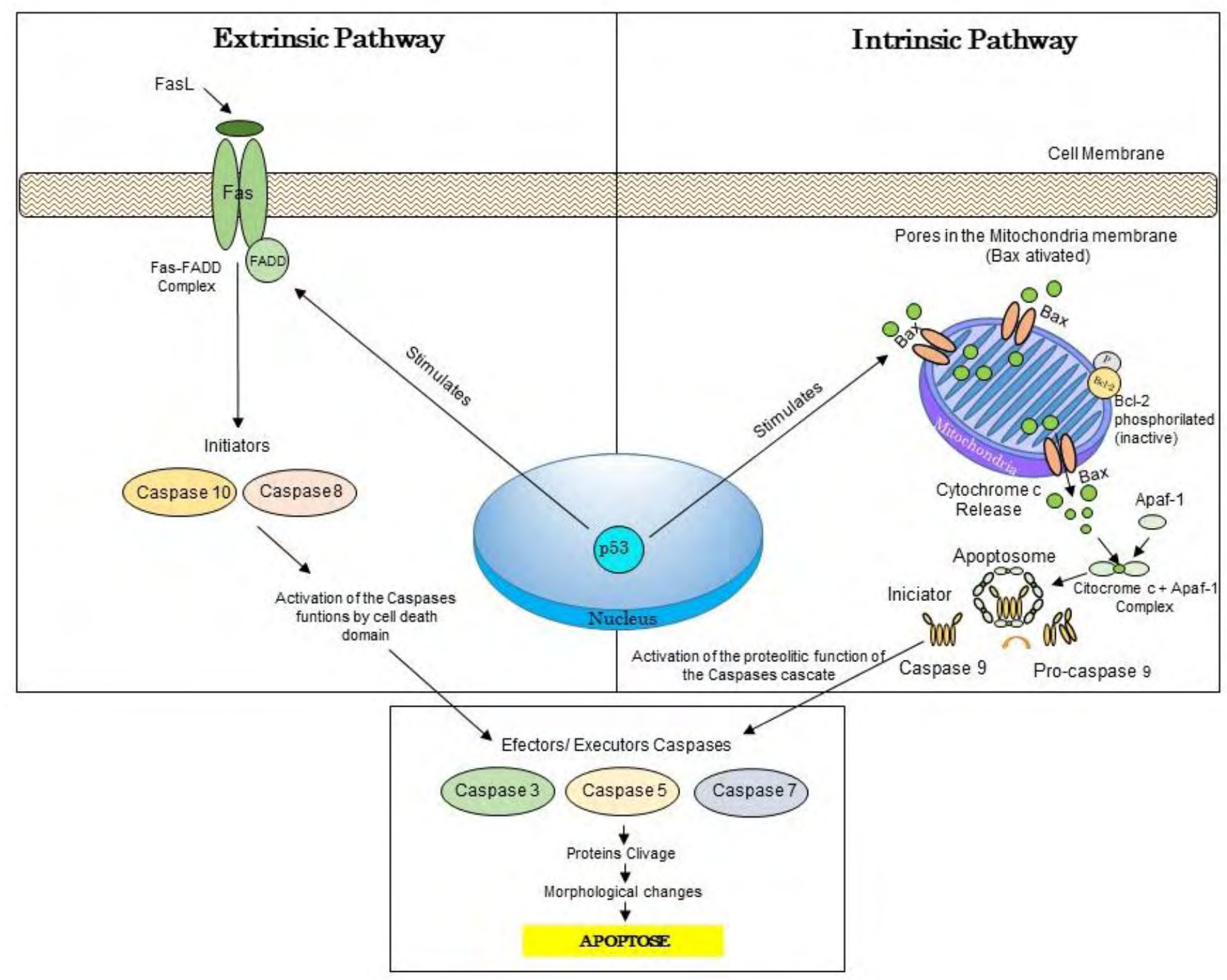

Figure 3. Scheme of the intrinsic and extrinsic pathway of apoptosis.

Source: Adapted from Durairajanayagam; Agarwal; Ong (2015) 


\section{References}

ACCORSI, P. A. et al. Role of prolactin, growth hormone and insulin-like growth factor 1 in mammary gland involution in the dairy cow. Journal of Dairy Science, $v$. 85, n. 3, p. 507-513, 2002.

ADIN, G. et al. Effects of cooling dry cows under heat load conditions on mammary gland enzymatic activity, intake of food and water, and performance during the dry period and after parturition. Livestock Science, v. 124, n. 1-3, p. 189-195, 2009.

AFSAL, A. et al. Heat Stress and Livestock Adaptation: Neuro-endocrine regulation. International Journal of Veterinary and Animal Medicine, v. 1, n. 2, 2018.

AKERS, M. R. et al. Prolactin regulation of milk secretion and biochemical differentiation of mammary epithelial cells in periparturient cows. Endocrinology, v. 109, n. 1, p. 23-30, 1981.

AL-SAMAWI, K. A.; AL-HASSAN, M. J.; SWELUM, A. A. Thermoregulation of female Aardi goats exposed to environmental heat stress in Saudi Arabia. Indian Journal of Animal Research, v. 48, n. 4, p. 344, 2014.

AUCHTUNG, T. L. et al. Effects of photoperiod during the dry period on prolactin, prolactin receptor, and milk production of dairy cows. Journal of Dairy Science, $v$. 88, n. 1, p. 121-127, 2005.

BERNABUCCI, U. et al. Metabolic and hormonal acclimation to heat stress in domesticated ruminants. Animal, v. 4, p. 1167-1183, 2010.

BERNABUCCI, U. et al. Effect of summer season on milk protein fractions in Holstein cows. Journal of Dairy Science, v. 98, n. 3, p. 1815-1827, 2015.

BERNABUCCI, U.; CALAMARI, L. Effects of heat stress on bovine milk yield and composition. Zootecnica e Nutrizione Animale, v. 24, p. 247-257, 1998.

BIANCA, W.; KUNZ, P. Physiological reactions of three breeds of goats to cold, heat and high altitude. Livestock Production Science, v. 5, n. 1, p. 57-69, 1978. 
BOHEN, S. P.; YAMAMOTO, K. R. Modulation of steroid receptor signal transduction by heat shock proteins. The Biology of Heat Shock Proteins and Molecular

Chaperones, v. 26, p. 313-334, 1994.

BOULANT, J. A. Role of the preoptic-anterior hypothalamus in thermoregulation and fever. Clinical Infectious Diseases, v. 31, n. 5, p. 157-161, 2000.

BOYAZOGLU, J.; HATZIMINAOGLOU, I.; MORAND-FEHR, P. The role of the goat in society: Past, present and perspectives for the future. Small Ruminant Research, v. 60 , n. 1, p. 13-23, 2005.

BRASIL, L. H. A. et al. Efeitos do estresse térmico sobre a produção, composição química do leite e respostas termorreguladoras de cabras da raça alpina. Revista Brasileira de Zootecnia, v. 29, n. 6, p. 1632-1641, 2000.

BROWN, D. L.; MORRISON, S. R.; BRADFORD, G. E. Effects of ambient temperature on milk production of Nubian and Alpine goats. Journal of Dairy Science, v. 71, n. 9, p. 2486-2490, 1988.

CABANAC, M. Temperature Regulation. Annu. Rev. Physiology, v. 3, p. 415-439, 1975.

CAPUCO, A. V.; AKERS, R. M.; SMITH, J. J. Mammary growth in Holstein cows during the dry period: quantification of nucleic acids and histology. Journal of Dairy Science, v. 80, n. 3, p. 477-487, 1997.

DANGI, S. S. et al. Expression profile of HSP genes during different seasons in goats (Capra hircus). Tropical Animal Health and Production, v. 44, n. 8, p. 1905-12, 2012.

DANGI, S. S. et al. Impact of short-term heat stress on physiological responses and expression profile of HSPs in Barbari goats. International Journal of

Biometeorology, v. 58, n. 10, p. 2085-93, 2014.

DANGI, S. S. et al. Expression of HSPs: an adaptive mechanism during long-term heat stress in goats (capra hircus). International Journal of Biometeorology, v. 59, n. 8, p. 1095-1106, 2015. 
DARCAN, N.; GÜNEY, O. Alleviation of climatic stress of dairy goats in

Mediterranean climate. Small Ruminant Research, v. 74, n. 1, p. 212-215, 2008.

DESHAIES, R. J. et al. A subfamily of stress proteins facilitates translocation of secretory and mitochondrial precursor polypeptides. Nature, v. 332, n. 6167, p. 8005, 1988.

Do AMARAL, B. C. et al. Heat-stress abatement during the dry period: Does cooling improve transition into lactation? Journal of Dairy Science, v. 92, n. 12, p. 59885999, 2009.

Do AMARAL, B. C. et al. Heat stress abatement during the dry period influences metabolic gene expression and improves immune status in the transition period of dairy cows. Journal of Dairy Science, v. 94, n. 1, p. 86-96, 2011.

DOBSON, H.; SMITH, R. F. What is stress, and how does it affect reproduction? Animal Reproduction Science, v. 60-61, p. 743-52, 2000.

DU, J. et al. Hyperthermia causes bovine mammary epithelial cell death by a mitochondrial-induced pathway. Journal of Thermal Biology, v. 33, n. 1, p. 37-47, 2008.

DURAIRAJANAYAGAM, D.; AGARWAL, A.; ONG, C. Causes, effects and molecular mechanisms of testicular heat stress. Reproductive BioMedicine Online, v. 30, n. 1, p. 14-27, 2015.

EHRNSPERGER, M. et al. Binding of non-native protein to Hsp25 during heat shock creates a reservoir of folding intermediates for reactivation. The EMBO journal, $v$. 16, n. 2, p. 221-9, 1997.

FORSYTH, I. A. Variation among species in the endocrine control of mammary growth and function: the roles of prolactin, growth hormone, and placental lactogen. Journal of Dairy Science, v. 69, n. 3, p. 886-903, 1986.

GARRIDO, C. et al. Heat Shock Proteins: endogenous modulators of apoptotic cell death. Biochemical and Biophysical Research Communications, v. 286, n. 3, p. 433-442, 2001. 
GRANDIN, T. Behavioural principles of handling cattle and other grazing animals under extensive condition. In GRANDIN, T. Livestock Handling and Transport. 2. ed. Cabi Publishing: Wallingford, p. 63-85, 2000.

GREEN, K. A.; STREULI, C. H. Apoptosis regulation in the mammary gland. Cellular and molecular life sciences: CMLS, v. 61, n. 15, p. 1867-83, 2004.

HAMMEL, H. T.; PIERCE, J. B. Regulation of internal body temperature. Annu. Rev. Physiology, v. 30, p. 641-710, 1968.

HAMZAOUI, S. et al. Physiological responses and lactational performances of latelactation dairy goats under heat stress conditions. Journal of Dairy Science, v. 96, n. 10, p. 6355-6365, 2013.

HOROWITZ, M. From molecular and cellular to integrative heat defense during exposure to chronic heat. Comparative Biochemistry and Physiology Part A: Molecular \& Integrative Physiology, v. 131, n. 3, p. 475-483, 2002.

$\mathrm{HU}, \mathrm{H}$. et al. The effect of heat stress on gene expression and synthesis of heatshock and milk proteins in bovine mammary epithelial cells. Animal Science Journal, v. 87, n. 1, p. 84-91, 2016.

KERR, S. Livestock Heat stress: Recognition, Response, and Prevention. Washington State University extension fact sheet, 2015.

KIANG, J. G.; TSOKOS, G. C. Heat Shock Protein 70 kDa: molecular biology, biochemistry, and physiology. Pharmacology \& Therapeutics, v. 80, n. 2, p. 183201, 1998.

KREGEL, K. C. Heat shock proteins: modifying factors in physiological stress responses and acquired thermotolerance. Journal of Applied Physiology, v. 92, n. 5, p. 2177-2186, 2002.

LU, C. D. Effects of heat stress on goat production. Small Ruminant Research, v. 2, n. 2, p. 151-162, 1989. 
MACARIO, A. J. L.; MACARIO, E. C. DE. Molecular chaperones: Multiple functions, pathologies, and potencial applications. Frontiers in Bioscience, v. 12, p. 25882600, 2007.

MAIA, A. S. C. et al. Thermoregulatory responses of goats in hot environments. International Journal of Biometeorology, v. 59, n. 8, p. 1025-1033, 2015.

MAIA, A. S. C. et al. Thermal equilibrium of goats. Journal of Thermal Biology, v. 58, p. 43-49, 2016.

McMANUS, C. et al. Heat tolerance in naturalized Brazilian cattle breeds. Livestock Science, v. 120, n. 3, p. 256-264, 2009.

MILARSKI, K.; MORIMOTO, R. Expression of human HSP70 during the synthetic phase of the cell cycle. Proceedings of the National, 1986.

MOHANARAO, G. J. et al. HSP70 family genes and HSP27 expression in response to heat and cold stress in vitro in peripheral blood mononuclear cells of goat (Capra hircus). Small Ruminant Research, v. 116, n. 2-3, p. 94-99, 2014.

MOSELEY, P. L. Heat shock proteins and heat adaptation of the whole organism. Journal of Applied Physiology, v. 83, n. 5, p. 1413-1417, 1997.

NARDONE, A. et al. Effects of climate changes on animal production and sustainability of livestock systems. Livestock Science, v. 130, n. 1-3, p. 57-69, 2010.

NIENABER, J. A.; HAHN, G. L. Livestock production system management responses to thermal challenges. International Journal of Biometeorology, v. 52, p. 149-157, 2007.

NØRGAARD, J. V et al. Cellular mechanisms in regulating mammary cell turnover during lactation and dry period in dairy cows. Journal of Dairy Science, v. 91, n. 6, p. 2319-27, 2008.

RIBEIRO, N. L. et al. Adaptive profile of Garfagnina goat breed assessed through physiological, haematological, biochemical and hormonal parameters. Small

Ruminant Research, v. 144, p. 236-241, 2016. 
ROUT, P. K.; KAUSHIK, R.; RAMACHANDRAN, N. Differential expression pattern of heat shock protein 70 gene in tissues and heat stress phenotypes in goats during peak heat stress period. Cell Stress and Chaperones, v. 21, n. 4, p. 645-651, 2016.

ROWSON, A. R. et al. Growth and development of the mammary glands of livestock: a veritable barnyard of opportunities. Seminars in Cell \& Developmental biology, v. 23, n. 5, p. 557-66, 2012.

SALAMA, A. A. K. et al. Different levels of response to heat stress in dairy goats. Small Ruminant Research, v. 121, n. 1, p. 73-79, 2014.

SANO, H.; AMBO, K.; TSUDA, T. Blood glucose kinetics in whole body and mammary gland of lactating goats exposed to heat. Journal of Dairy Science, v. 68, n. 10, p. 2557-64, 1985.

SHILJA, S. et al. Adaptive capability as indicated by behavioral and physiological responses, plasma HSP70 level, and PBMC HSP70 mRNA expression in Osmanabadi goats subjected to combined (heat and nutritional) stressors. International Journal of Biometeorology, v. 60, n. 9, p. 1311-1323, 2016.

SILANIKOVE, N. Effects of heat stress on the welfare of extensively managed domestic ruminants. Livestock Production Science, v. 67, p. 1-18, 2000a.

SILANIKOVE, N. The physiological basis of adaptation in goats to harsh environments. Small Ruminant Research, v. 35, n. 3, p. 181-193, 2000 b.

SILANIKOVE, N.; KOLUMAN, D. N. Impact of climate change on the dairy industry in temperate zones: Predications on the overall negative impact and on the positive role of dairy goats in adaptation to earth warming. Small Ruminant Research, v. 123, n. 1, p. 27-34, 2015.

SILVA, R. G. Introdução à bioclimatologia animal. São Paulo: Ed. Nobel, 2000.

SMITH, J. J. et al. Association of prolactin and insulin receptors with mammogenesis and lobulo-alveolar formation in pregnant ewes. International Journal of Biochemistry, v. 21, n. 1, p. 73-81, 1989. 
SØRENSEN, J. G.; KRISTENSEN, T. N.; LOESCHCKE, V. The evolutionary and ecological role of heat shock proteins. Ecology Letters, v. 6, n. 11, p. 1025-1037, 2003.

SWANSON, E. W.; POFFENBARGER, J. I. Mammary gland development of dairy heifers during their first gestation. Journal of Dairy Science, v. 62, n. 5, p. 702-14, 1979.

$\mathrm{TAO}, \mathrm{S}$. et al. Effect of heat stress during the dry period on mammary gland development. Journal of Dairy Science, v. 94, n. 12, p. 5976-5986, 2011.

TAO, S.; DAHL, G. E. Invited review: heat stress effects during late gestation on dry cows and their calves. Journal of Dairy Science, v. 96, n. 7, p. 4079-93, 2013.

URIBE-VELASQUEZ, L. F. et al. Concentrações plasmáticas de cortisol, hormônios tiroídeanos, metabólitos lipídicos e temperatura corporal de cabras alpinas submetidas ao estresse térmico. Revista Brasileira de Zootecnia, v. 27, n. 6, p. 1123-1130, 1998.

WOLFENSON, D.; FLAMENBAUM, I.; BERMAN, A. Dry period heat stress relief effects on prepartum progesterone, calf birth weight, and milk production. Journal of dairy science, v. 71, n. 3, p. 809-18, 1988.

ZARZYNSKA, J.; MOTYL, T. Apoptosis and autophagy in involuting bovine mammary gland. Journal of Physiology and Pharmacology, v. 59 Suppl 9, p. 27588, 2008. 


\title{
2. ACUTE HEAT STRESS INDUCES CHANGES IN PHYSIOLOGICAL AND CELLULAR RESPONSES IN SAANEN GOATS
}

The following chapter of the present Thesis, refers to the Article accepted on $5^{\text {th }}$ of October, 2018, by the International Journal of Biometeorology (Impact factor: 2.577).

Intemational Journal of Biometeorology

https:/doi.org/10.1007/s00484-018-1630-3

ORIGINALPAPER

\section{Acute heat stress induces changes in physiological and cellular responses in Saanen goats}

\author{
Henrique Barbosa Hooper ${ }^{\prime}$ - Priscila dos Santos Silva' . Sandra Aparecida de Oliveira ' . \\ Giovana Krempel Fonseca Merighe' . Joâo Alberto Negrāo?
}

Received 15 December 2017 / Revised: 7 August 2018 / Accepted: 5 October 2018

if $19 \mathrm{~B} 2018$

\begin{abstract}
The relafionships between rectal temperatures and physiological and cellular responses to beat stress can improve flue productivity of Saanen goats in tropical environmenis. In this context, this study evaluated the ploysiological responses and gene expression of heat shock proteins (IISP60), 70, and 90) and genes related to apoptosis (Bax. Bc- -2, and p53) of Saanen gosts subjoctiod to acute heat mess. Ten health Saancn goats were exposod to solar radiation duning 3 consecutive days. The expression of HSP60, HSP70, HSP90, Bax, $\mathrm{Bcl}-2$, and $p 53$ genes in blcod leukocytes. rectal and superficial temperatures, respiratory frequency, cortisol, thiodotbyronine, and thyroxine was measured at $0600,13: 00$, and $18: 00 \mathrm{~h}$. In vitro, blood leukocyles were suhjected to $38^{\circ} \mathrm{C}$ and $40{ }^{\circ} \mathrm{C}$ for 3 h to measure the expression of the same target genes. The temperabure humidity index, measured from 12:00 w 15:00, was greater thàn 80 arul black globe temperatures were greater at $40^{\circ} \mathrm{C}$, indicating the intensity of the solar radiation. Although the solar radiation cansed acuie fieat stress, increased cortisol release, and the expression of HSP60 and 70 in dry Saanen goats, the increased respiratory frequency and decreased $\mathrm{T} 4$ and $\mathrm{T} 3$ restored the homeothetmy of the experinental goats. In vitro, the $40^{\circ} \mathrm{C}$ increased the expression of p53 (proapoptotic protein), Bcl-2 (anti-apoptotic protein). HSP60, HSP70, and HSP90, suggesting that these genes have protective functions. However, further studies are neesssary to understand the physiological and cellular responses to heat stress.
\end{abstract}

Keywords Cortisol-Bax-Bcl-2 - p53 - HSP60-HSP70 


\section{Abstract}

The relationships between rectal temperature, physiological and cellular responses to heat stress can improve the productivity of Saanen goats in tropical environments. In this context, this study evaluated the physiological responses and gene expression of heat shock proteins (HSP 60, 70, and 90) and genes related to apoptosis (Bax, Bcl-2, and p53) of Saanen goats subjected to acute heat stress. Ten health Saanen goats were exposed to solar radiation during three consecutive days. The expression of HSP60, HSP70, HSP90, Bax, Bcl-2, and p53 genes in blood leukocytes, rectal and superficial temperatures, respiratory frequency, cortisol, triiodothyronine, and thyroxine were measured at 06:00, 13:00, and 18:00 hours. In vitro, blood leukocytes were subjected to $38^{\circ} \mathrm{C}$ and $40^{\circ} \mathrm{C}$ for three hours to measure the expression of the same target genes. The temperature humidity index, measured from 12:00 to 15:00 $\mathrm{h}$, was greater than 80 and black globe temperatures were greater at $40^{\circ} \mathrm{C}$, indicating the intensity of the solar radiation. Although the solar radiation caused acute heat stress, increased cortisol release, and the expression of HSP60 and HSP70 in dry Saanen goats, the increased respiratory frequency and decreased T3 and T4 restored the homeothermy of the experimental goats. In vitro, the $40^{\circ} \mathrm{C}$ increased the expression of p53 (pro-apoptotic protein), Bcl-2 (anti-apoptotic protein), HSP60, HSP70, and HSP90, suggesting that these genes have protective functions. However, further studies are necessary to understand the physiological and cellular responses to heat stress.

Keywords: cortisol; Bax; Bcl-2; p53; HSP60, HSP70. 


\section{Resumo (Portuguese)}

As relações entre temperatura retal, respostas fisiológicas e celulares ao estresse por calor podem melhorar a produtividade de caprinos da raça Saanen em ambiente tropical. Neste contexto, este estudo avaliou as respostas fisiológicas e expressão gênica de proteínas de choque térmico (HSP 60, 70 e 90) a genes relacionados à apoptose (Bax, Bcl-2 e p53) de cabras Saanen expostas à estresse agudo. Dez cabras Saanen saudáveis foram expostas à radiação solar durante três dias consecutivos. Foram avaliados às 6:00, 13:00 e 18:00 horas a expressão gênica de HSP60, HSP70, HSP90, Bax, Bcl-2 e p53 nas células sanguíneas leucocitárias, temperatura retal e superficial, frequência respiratória, cortisol, triiodotironina e tiroxina. In vitro, os leucócitos foram submetidos às temperaturas $38^{\circ} \mathrm{C}$ e $40^{\circ} \mathrm{C}$ por três horas para medir a expressão dos mesmos genes alvo referidos anteriormente. O índice de temperatura e umidade, medido das 12:00 às 15:00 horas foi maior que 80 e a temperatura de globo negro foi maior que $40^{\circ} \mathrm{C}$, indicando a intensidade da radiação solar. Embora, a radiação solar causou estresse por calor agudo, aumentou a liberação de cortisol, e a expressão da HSP60 e HSP70 em cabras secas da raça Saanen, o aumento da frequência respiratória e redução de T3 e T4 reestabeleceram a homeotermia dos animais do experimento. In vitro, à $40^{\circ} \mathrm{C}$ houve o aumento da expressão da p53 (proteína pró-apoptótica), Bcl-2 (proteína antiapoptótica), HSP60, HSP70 e HSP90, o que sugere que esses genes desempenham funções na proteção celular. Entretanto, mais estudo são necessários para entender às respostas fisiológicas e celulares em estresse térmico.

Palavras-chave: Bax; Bcl-2; cortisol; HSP60; HSP70; p53. 


\subsection{Introduction}

Farm ruminants are constantly exposed to environmental factors and climate challenges that could cause stress and negatively impact their production and reproduction (MINTON, 1994; McMICHAEL et al., 2007; NARAYAN; PARISELLA, 2017; NARAYAN et al., 2018). In tropical latitudes, ruminants are maintained on grassland pasture and are exposed, most of the time, to intense solar radiation. In general, goats from hot climates are less susceptible to solar radiation, water deprivation, lower forage availability, and heat stress (BRASIL et al., 2000; SILVA et al., 2006). Goats are a good alternative to conventional animal production in hot climatic condition due to their ability to adapt to different environments (SILANIKOVE, 2000; SILVA et al., 2006). During heat stress, however, goats increase their rectal temperature, respiratory frequency, and sweating to change their body heat and show high cortisol (Cort) and low tyrosine (T4) and triiodotironine (T3) concentrations to maintain their homeothermy (MAIA et al., 2015; RIBEIRO et al., 2016).

In the same way, heat stress also triggers cellular responses and induces transcription and translation of several genes and changing protein synthesis (BERNABUCCI et al., 2010; JOHNSON; MCMICHAEL; WHITE, 2006; OHTSUBO et al., 2001). The overexpression of heat shock proteins (HSPs) in the blood leukocytes of Barbari goats in hotter seasons suggests a protective role of HSPs for maintaining cell integrity (DANGl et al., 2012). Additionally, other authors have suggested that HSP60, HSP70, and HSP90 have essential roles in cell survival by preventing apoptosis during different stress events (HARTL; BRACHER; HAYER-HARTL, 2011; $\mathrm{HU}$ et al., 2016a; LANNEAU et al., 2007). In contrast, p53 is a key regulator of apoptosis and both Bcl-2 (anti-apoptotic) and Bax (pro-apoptotic) proteins also have important roles in the regulation of cell survival (CHEN; CHUANG, 1999; DU et al., 2008; GU et al., 2014). In fact, cell survival depends of the synthesis and accumulation of protective (HSPs, Bcl-2) or apoptotic proteins (p53 and Bax).

In this context, the relationships between physiological and cellular responses to heat stress can improve the effectiveness of genetic selection of Saanen goats for tropical climates (MCMANUS et al., 2009; PAULA-LOPES et al., 2003; PEREIRA et al., 2014) because goats mobilize thermoregulatory responses to maintain their homeothermy during heat stress. Thus, the information on Saanen goats that 
originated from temperate latitudes and bred for several generations in tropical latitudes is scarce. The objective of this study was to evaluate the relationships between body temperatures, physiological responses, and cellular responses in nonlactating Saanen goats exposed to acute heat stress caused by solar radiation exposure on thermoregulatory responses, Cort, T4 and T3 concentrations, and the expression of HSP60, HSP70, HSP90, p53, Bcl-2, and Bax in vivo and in vitro.

\subsubsection{Material and methods}

Experimental location

The present study was carried out at Animal Physiology laboratory, Animal Science and Food Engineering Faculty (FZEA), University of São Paulo (USP), Pirassununga $\left(21^{\circ} 58^{\prime} S\right.$ and $\left.47^{\circ} 26^{\prime \prime} \mathrm{W}\right)$, Brazil. The climate is classified, according to the Köeppen-Geiger classification, as subtropical humid. All animal procedures were in compliance with established ethical procedures and were approved by the ethic committee of the FZEA/USP.

Weather data

Air temperature (AT), black-globe temperature (BGT), and relative humidity $(\mathrm{RH})$ were recorded by a data logger (Onset $\mathrm{HOBO} B$, Cape Cod, MA, USA) during the experimental period. The influence exerted by the environment on the animals was described using the temperature and humidity index (THI) and calculated as described by Thom (1958): $\mathrm{THI}=\mathrm{AT}+0.36^{\star} \mathrm{DPT}+41.5$, where AT is air temperature and DPT is the dew point temperature, both in degrees Celsius. As previously reported (SILANIKOVE; KOLUMAN, 2015), the THI was classified as: normal when lower than 80; alert when $\leq 80$ and $<85$; danger when $\leq 85$ and $<90$; and extreme when $\geq 90$.

The details concerning AT, BGT, $\mathrm{RH}$, and THI from 06:00 to 18:00 $\mathrm{h}$ are shown in Table 1. During the in vivo study, the maximum AT $\left(33.20^{\circ} \mathrm{C}\right)$ and BGT $\left(43.88^{\circ} \mathrm{C}\right)$ were recorded at $14: 00$ and 13:00 $\mathrm{h}$ respectively, indicating the intensity of solar radiation imposed on the goats. The discomfort or stress of the experimental goats 
was measured by the THI and the THI measured from 12:00 to 15:00 hours (h) was classified as the alert condition because the THI was above 80 (Table 1).

Animals, pens and diets

Ten healthy, female, dry 5-year-old Saanen goats with an average body weight of $46.2 \pm 5.6 \mathrm{~kg}$ were used in the present study. Experimental goats were maintained in collective covered pens with free access to shade, feed, water, and mineral salt in collective troughs. Experimental goats received a total diet (corn silage and mixed grains at 60:40) twice a day (at 08:00 and 16:00 h). Taking into account the age, category, body weight, and body condition score, the diet was adjusted to provide $100 \%$ of the animal's dietary needs (NRC, 2007), and feed intake was adjusted daily with $10 \%$ of leftovers.

Experimental procedures

In the present study, two experiments were performed, one in vivo and another in vitro. In the in vivo experiment, the Saanen goats were exposed to solar radiation during three consecutive typical days of spring in an area without any type of shade $\left(420 \mathrm{~m}^{2}\right.$ of total area, fenced, smooth concrete floor, with 3 feeder and two water troughs) where they remained from 07:00 to 17:00 $\mathrm{h}$ (experimental challenge) but with access to feed and water. During the in vivo study, all data were performed at the 06:00 (before), 13:00 (during), and 18:00 $\mathrm{h}$ (after exposure to solar radiation). Afterwards, experimental goats came back to the covered pens described above, with free access to shade, feed, water, and mineral salt. In this experiment, the control group was the own goats, in which the treatment data were compared with the thermal neutral period data (at 7:00 h). Beyond the treatment, the animals were constantly accompanied by checking physiological and responsiveness to the environment. Moreover, the instant environment data were checked. Those observations could ensure animal status in face of heat stress in order to do not overpass the threshold of life risk. 
Table 1. Mean \pm standard error of mean of air temperature (AT), black globe temperature (BGT), relative humidity $(\mathrm{RH})$, and temperature humidity index (THI) by hour measured during the in vivo experiment.

\begin{tabular}{|c|c|c|c|c|c|c|c|c|c|c|c|c|c|c|}
\hline \multirow[b]{2}{*}{ Items } & \multicolumn{13}{|c|}{ Hours } & \multirow{2}{*}{$\begin{array}{c}\mathrm{P} \text { - } \\
\text { value }\end{array}$} \\
\hline & $06: 00^{*}$ & 07:00 & 08:00 & 09:00 & $10: 00$ & 11:00 & $12: 00$ & $13: 00^{*}$ & $14: 00$ & $15: 00$ & $16: 00$ & $17: 00$ & $18: 00^{*}$ & \\
\hline $\mathrm{AT}\left({ }^{\circ} \mathrm{C}\right)$ & $19.59 \mathrm{c}$ & 21.31 & 23.66 & 25.33 & 27.49 & 28.99 & 31.00 & $32.05 \mathrm{a}$ & 33.20 & 31.14 & 28.82 & 28.02 & $26.63 \mathrm{~b}$ & $<0.001$ \\
\hline BGT $\left({ }^{\circ} \mathrm{C}\right)$ & $19.25 \mathrm{c}$ & 21.85 & 24.67 & 26.37 & 29.53 & 32.07 & 34.04 & $40.93 \mathrm{a}$ & 43.88 & 35.23 & 30.75 & 29.22 & $25.51 \mathrm{~b}$ & $<0.001$ \\
\hline RU (\%) & $87.53 \mathrm{a}$ & 84.13 & 76.12 & 70.13 & 64.31 & 61.22 & 60.20 & $51.36 \mathrm{c}$ & 47.47 & 49.47 & 60.87 & 63.23 & $69.60 \mathrm{~b}$ & $<0.001$ \\
\hline $\mathrm{THI}^{\dagger}$ & $67.24 \mathrm{c}$ & 69.34 & 71.96 & 73.80 & 76.32 & 78.14 & 80.20 & $81.59 a$ & 82.87 & 80.21 & 77.88 & 76.96 & $71.43 \mathrm{~b}$ & $<0.001$ \\
\hline
\end{tabular}

${ }^{*}$ Different letters at 06:00 (before), 13:00 (during), and 18:00 h (after solar radiation) represent $\mathrm{P} \leq 0.05$.

†THI was class as alert condition to dairy goats from 12:00 pm to 15:00 pm. 
In the in vitro experiment, blood tubes were submitted to one of two treatments in different water baths: one at $38^{\circ} \mathrm{C}$ (control treatment) and another at $40^{\circ} \mathrm{C}$ (acute heat stress treatment) for three hours. In both studies, the blood leukocytes (peripheral blood mononuclear cells - PBMCs) were used as a cellular model because these cells have been used in several studies to evaluate heat stress responsiveness (DANGI et al., 2012; GUERRIERO; RAYNES, 1990; KISHORE et al., 2013).

Data collection and sampling

The respiratory frequency $(\mathrm{RF})$ and rectal $(\mathrm{RT})$, dorsal (DT), tail (TT), ocular (OT), and mammary gland (MT) temperatures were measured during the three days of solar exposure at the 06:00, 13:00, and 18:00 h. RF was determined with a stethoscope placed on the rib spaces to obtain the breath movements per minute (bpm). RT was measured with a calibrated clinical thermometer with a precision of $0.10^{\circ} \mathrm{C}$. DT and TT were measured by an infrared thermometer with a precision of \pm $2^{\circ} \mathrm{C}$ (Incoterm, MultiTemp portable, Porto Alegre, Rio Grande do Sul, Brazil). OT and MT were measured by infrared thermography (Testo ${ }^{\circledR} 875-2 i$ camera, Melbourne, Victoria, Australia), with an emissivity of 0.98 , accuracy of $\pm 2{ }^{\circ} \mathrm{C}$, and thermal sensibility $<50 \mathrm{mK}$. The images obtained were analyzed using IRSoft software (version 4.0), taking into account the analyses performed in other studies (WESCHENFELDER et al. 2013; ALEJANDRO et al. 2014; SATHIYABARATHI et al. 2016). The OT was drawn from a circle on the eye, limited by the medial and lateral commissures, and the MT was obtained by drawing a rectangle at the central part of both glands, limited by the legs (Figure 1).

Just after the physiological measurements were performed, blood was sampled at 06:00, 13:00, and 18:00 $\mathrm{h}$ from each animal by jugular venipuncture in heparin and EDTA tubes for hormone assay and gene expression studies, respectively. Blood with EDTA was centrifuged at $1.500 \mathrm{~g}$ for $20 \mathrm{~min}$ at $4^{\circ} \mathrm{C}$ and the leukocyte layer was transferred to a microtube and $1 \mathrm{ml}$ of hemolysis solution $(300 \mathrm{ml}$ of ultrapure water, $54.8 \mathrm{~g}$ of sucralose, $6 \mathrm{ml}$ of Tris- $\mathrm{HCl}, 2.5 \mathrm{ml}$ of $\mathrm{MgCl}_{2}$, and $5 \mathrm{ml}$ of Triton $1 \%$ ) was added to the leukocyte layer. Afterward, the leukocyte layer with hemolysis solution was centrifuged at $12.000 \mathrm{~g}$ for $2 \mathrm{~min}$ at $24^{\circ} \mathrm{C}$. The supernatant was discharged by 
inversion and the pellet containing the PBMCs was maintained at $-80^{\circ} \mathrm{C}$ until the RNA extraction.
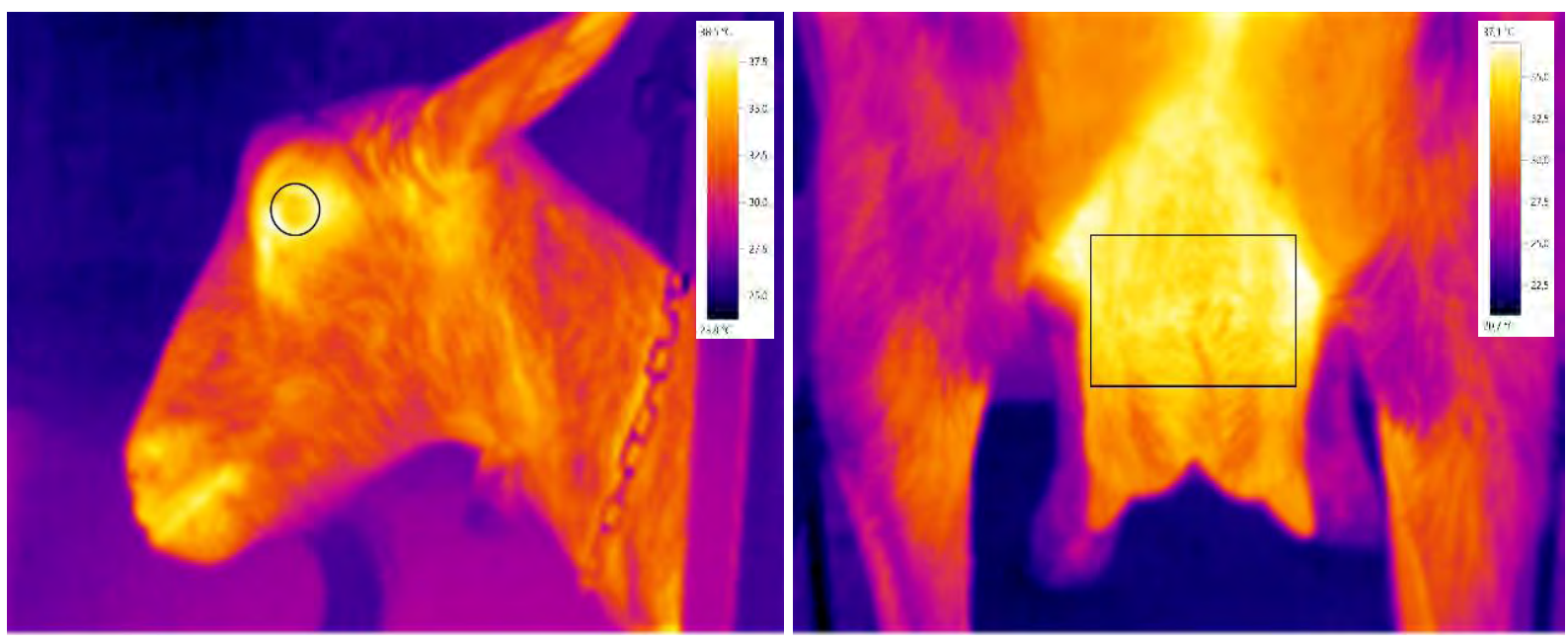

Figure 1. Scheme used to obtain the superficial temperature of the ocular region and mammary gland. The mean of the ocular temperature was calculated by IRsoft 3.6 software using $1 \mathrm{~cm}$ of the radium; the mean mammary temperature was calculated using the middle of the mammary gland as a reference, taking a rectangle of $8 \times 6$ $\mathrm{cm}$. Source: Own Authorship.

Blood with heparin also was centrifuged at $1.500 \mathrm{~g}$ for $20 \mathrm{~min}$ at $4^{\circ} \mathrm{C}$ and the plasma was stored at $-20^{\circ} \mathrm{C}$ until hormone analysis. Cort (catalog number: 3625300), T4 (catalog number: 225-300), and T3 (catalog number: 125-300) were measured using immunoassay kits (Monobind Inc., Lake Forest, CA, USA) with sensitivities of $0.25 \mu \mathrm{g} / \mathrm{dl}, 0.04 \mathrm{ng} / \mathrm{ml}$, and $0.04 \mu \mathrm{g} / \mathrm{dl}$, respectively. The Cort intraand inter-assay coefficients of variation were $2.8 \%$ and $6.5 \%$, respectively. The T4 intra- and inter-assay coefficients of variation were $2.3 \%$ and $3.5 \%$, respectively. The T3 intra- and inter-assay coefficients of variation were $3.6 \%$ and $4.1 \%$, respectively.

Total RNA was extracted and purified using a Purelink RNA Mini Kit (Invitrogen, Carlsbad, CA, USA). The RNA concentrations were determined by Qubit ${ }^{\circ} 2.0$ Fluorometric Quantification (Thermo Fisher Scientific, Wilmington, DE, USA). The total RNA obtained was treated with RNase-Free DNase (Promega, Madison, WI, USA) to exclude genomic DNA contamination from the analysis. The RNA was reverse-transcribed into cDNA using a GoScript TM Reverse Transcriptase kit (Promega, Madison, WI, USA). The qPCR analyses were performed using a PCR-RT machine (Invitrogen, Carlsbad, CA) with SYBR® Green (Invitrogen, Carlsbad, CA, USA) as the fluorescent label. Each qPCR reaction had a total volume of $20 \mu$ l and 
was performed using 96-well plates (Invitrogen, Carlsbad, CA, USA) and transparent adhesive tapes.

The reaction mixture was comprised of $1 \mu \mathrm{l}$ of cDNA (mean concentration of 10 $\mathrm{ng} / \mu \mathrm{l}$ ), $10 \mu \mathrm{l}$ of $\mathrm{SYBR} \AA^{\circledR}$ Green Mix, $0.8 \mu \mathrm{l}$ of the primer pair (final concentration 0.4 $\mu \mathrm{M})$, and $8.2 \mu \mathrm{l}$ of ultrapure water. A control reaction was included in each assay to detect contamination. The primers used in this study were for HSP60, HSP70, HSP90, Bax, Bcl-2, p53, and GAPDH (as a housekeeping gene) and all were sequenced (Table 2). The qPCR thermocycling conditions for all genes was the incubation stage at $95^{\circ} \mathrm{C}$ for 10 minutes; 40 cycles of $95^{\circ} \mathrm{C}$ for 15 seconds and $60 \stackrel{\circ}{ } \mathrm{C}$ for 1 minute; and finished with a dissociation curve. For each set of primers, the PCR efficiency was close to $100 \%$, all primer pairs used were confirmed for their PCR efficiency, and specific products were checked by melt curve analysis and $1.5 \%$ agarose gel electrophoresis. Relative quantification of target genes was done using the Livak and Schmittgen (2001) method by comparing the expression level of the target gene with the reference gene (GAPDH).

Statistical analysis

The data were analyzed using the Statistical Analysis System (SAS, 2008). The normality of the data was confirmed using the Shapiro-Wilk test. Afterwards, the body temperatures and hormonal release data were subjected to an analysis of variance by the MIXED procedure of SAS. In the model, the treatment effect (exposition to solar radiation) was considered fixed and the effects of the day, time of sampling (06:00 $\mathrm{h}$ before, 13:00 $\mathrm{h}$ during and 18:00 $\mathrm{h}$ after solar radiation), and the animals were considered as random effects. As the three days of experiment were typical of spring and did not differ, the effect of the day was excluded from the model. Gene expression in vivo and in vitro were subjected to an analysis of variance by the GLM procedure of SAS, which separated the in vivo (exposition to solar radiation) and in vitro $\left(38\right.$ or $\left.40^{\circ} \mathrm{C}\right)$ treatments, the time of sampling, and the animals as causes of variation. In the model, the treatment effect was considered fixed and the effects of the animals were considered random. Several errors of covariance structures were tested, and the one that best fit the data according to the Bayesian information criterion was selected. Pearson correlations were considered to estimate the 
relations between body temperatures, physiological and cellular responses, and weather data. When there was a significant effect, the means were compared using Fisher's test. Significance was defined as $\mathrm{P} \leq 0.05$.

\subsubsection{Results}

The THI measured from 12:00 to 15:00 $\mathrm{h}$ was classified as the alert condition because to the THI was greater than 80 , at that point and BGT was superior at $40{ }^{\circ} \mathrm{C}$, indicating the intensity of solar radiation at that time. Consequently, during the in vivo experiment, there was a significant effect of sampling time on RT, DT, TT, OT, and MT, RF, Cort, T4, and T3 concentrations and HSP60, HSP70, and HSP90 expression levels when comparing the means obtained before (06:00 h), during $(13: 00 \mathrm{~h})$, and after $(18: 00 \mathrm{~h})$ the solar radiation. However, there was no effect of sampling time on the expression of $\mathrm{Bax}, \mathrm{Bcl}-2$, or p53 genes, nor on the relation between the Bcl-2 and Bax genes (Table 2).

In fact, the increased body temperatures, RF, Cort concentration, HSP60 and HSP90 expression of the goats were significantly influenced by solar radiation exposure, with higher values at 13:00 $\mathrm{h}$ than those measured at 06:00 and 18:00 $\mathrm{h}$ (Table 2). Thus, HSP70 expression was lower at 06:00 $\mathrm{h}$ than at 13:00 and 18:00 $\mathrm{h}$. In contrast, there was a reduced T4 concentration at 13:00 $\mathrm{h}$ compared to that at 06:00 and 18:00 h (Table 2).

In the same way, there were significant correlations between AT, BGT, $\mathrm{RH}$, and $\mathrm{THI}$ and body temperatures, physiological responses, and cellular responses (Table 3). Notably, RT had a significant and positive correlation with MT $(r=0.93$; $P<$ $0.001)$, OT $(r=0.92 ; P<0.0001)$, DT $(r=0.94 ; P<0.0001)$ and TT $(r=0.87 ; P$ $<0.0001)$. Thus, there were significant correlations between RT and Cort $(r=0.67$; $P$ $<0.0001)$, BGT and Cort $(r=0.70 ; P<0.0001)$, and BGT and T4 $(r=-0.50, P=$ 0.007). Furthermore, there were significant correlations between MT and T4 $(r=-$ $0.41 ; P=0.03)$, MT and Cort $(r=0.74 ; P=0.004)$, and MT and HSP60 $(r=0.68 ; P=$ $0.001)$. 
Table 2. Mean \pm standard error of mean of rectal temperature (RT), dorsal temperature (DT), tail temperature (TT), ocular temperature (OT), mammary temperature (MT), respiratory frequency (RF), cortisol (Cort), thyroxine (T4), triiodothyronine (T3), and the relative expression of HSP60, HSP70, HSP90, Bax, $\mathrm{Bcl}-2$, p53, and $\mathrm{Bcl}-2$ / Bax genes measured during the in vivo experiment.

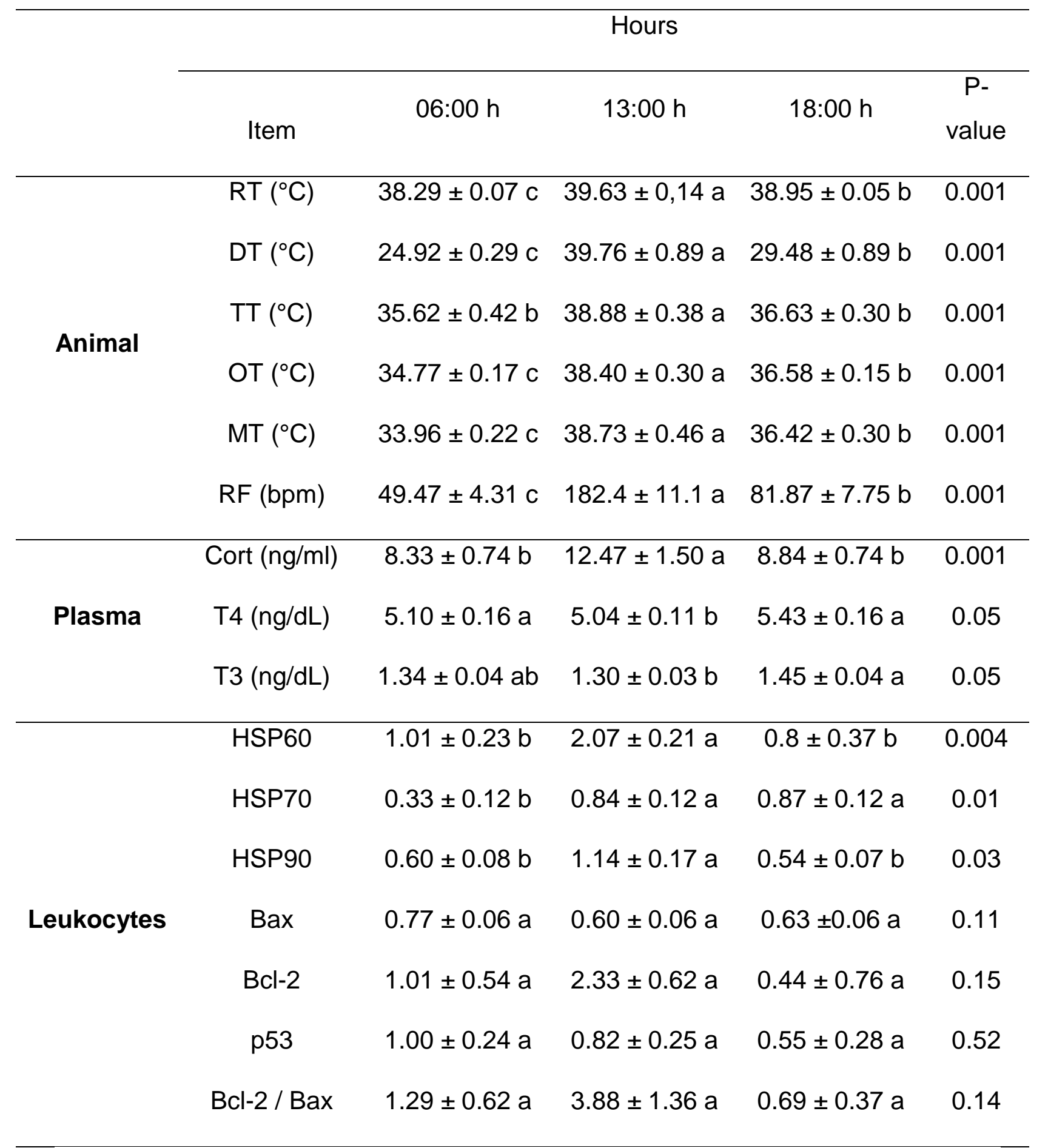

${ }^{*}$ Different letters at 06:00 (before), 13:00, (during) and 18:00 $\mathrm{h}$ (after solar radiation) represent $P \leq 0.05$. 
In the in vivo experiment, there was a significant effect of the treatment on the expression of the target genes. In fact, when compared to the $38^{\circ} \mathrm{C}$ treatment (control), leukocytes maintained in vitro at $40^{\circ} \mathrm{C}$ (heat stress) showed increased expression of the HSP60, HSP70, and HSP90 genes. In the same way, the $40^{\circ} \mathrm{C}$ treatment increased the expression of p53 (pro-apoptotic protein), Bcl-2 (antiapoptotic protein), and the relationship between the Bcl-2 and Bax genes due to higher Bcl-2 expression and the maintenance of Bax expression. In this case, the HSP70 gene was overexpressed when compared to the other genes studied (Fig. 2).
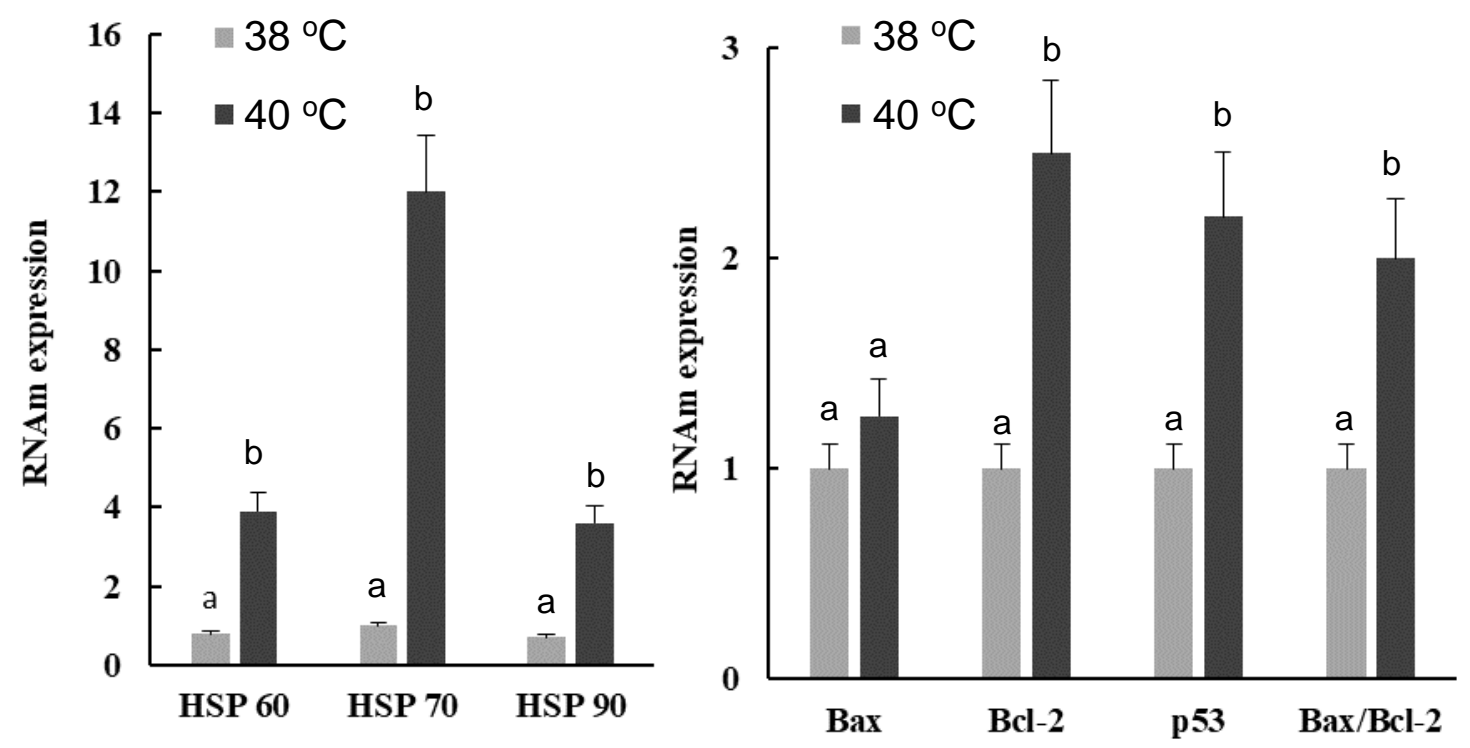

Figure. 2 Mean \pm standard error of mean of the relative expression of HSP60, HSP70, HSP90, Bax, Bcl-2, p53, and Bcl-2 / Bax genes on blood leukocytes subjected to $38^{\circ} \mathrm{C}$ or $40^{\circ} \mathrm{C}$, in vitro. Different letters on columns represent $\mathrm{P} \leq 0.05$. 
Table 3. Pearson's correlation coefficients among weather values, physiological responses, and cellular responses measured during the in vivo experiment.

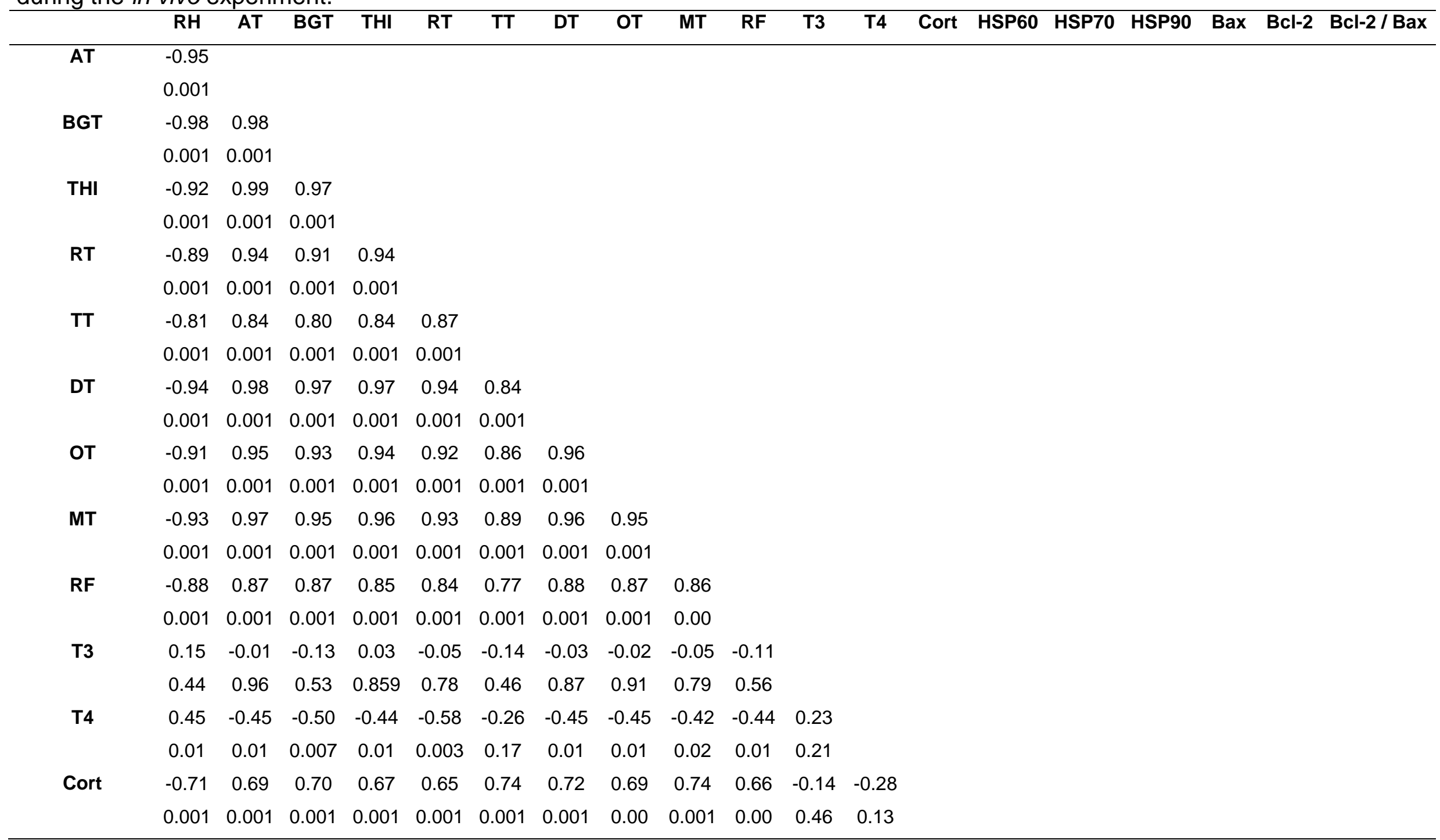




\begin{tabular}{|c|c|c|c|c|c|c|c|c|c|c|c|c|c|c|c|c|c|c|c|}
\hline Continuation... & RH & AT & BGT & THI & RT & TT & DT & OT & MT & $\mathbf{R F}$ & T3 & T4 & Cort & HSP60 & HSP70 & HSP90 & Bax & Bcl-2 & Bcl-2 / Bax \\
\hline \multirow[t]{2}{*}{ HSP60 } & -0.44 & 0.50 & 0.52 & 0.52 & 0.42 & 0.32 & 0.46 & 0.49 & 0.68 & 0.38 & -0.05 & -0.40 & 0.24 & & & & & & \\
\hline & 0.04 & 0.02 & 0.02 & 0.01 & 0.05 & 0.16 & 0.03 & 0.02 & 0.001 & 0.08 & 0.80 & 0.06 & 0.31 & & & & & & \\
\hline HSP70 & -0.01 & 0.02 & -0.03 & 0.01 & 0.08 & 0.02 & 0.07 & 0.02 & -0.03 & 0.03 & -0.03 & -0.14 & 0.02 & 0.55 & & & & & \\
\hline \multirow[t]{2}{*}{ HSP90 } & -0.31 & 0.25 & 0.28 & 0.22 & 0.34 & 0.33 & 0.33 & 0.31 & 0.26 & 0.28 & -0.28 & -0.36 & 0.53 & 0.45 & 0.47 & & & & \\
\hline & 0.08 & 0.187 & 0.15 & 0.27 & 0.06 & 0.07 & 0.06 & 0.09 & 0.18 & 0.12 & 0.13 & 0.04 & 0.003 & 0.04 & 0.01 & & & & \\
\hline \multirow[t]{2}{*}{ Bcl-2 } & -0.42 & 0.38 & 0.46 & 0.37 & 0.39 & 0.45 & 0.46 & 0.48 & 0.46 & 0.49 & -0.36 & -0.46 & 0.58 & 0.67 & 0.64 & 0.89 & -0.36 & & \\
\hline & 0.08 & 0.12 & 0.06 & 0.13 & 0.10 & 0.07 & 0.05 & 0.04 & 0.06 & 0.03 & 0.14 & 0.05 & 0.01 & 0.004 & 0.004 & 0.001 & 0.15 & & \\
\hline \multirow[t]{2}{*}{$\mathrm{Bcl-2} / \mathrm{Bax}$} & -0.46 & 0.43 & 0.51 & 0.42 & 0.38 & 0.49 & 0.53 & 0.52 & 0.48 & 0.59 & -0.24 & -0.32 & 0.56 & 0.54 & 0.51 & 0.74 & -0.53 & 0.92 & \\
\hline & 0.06 & 0.09 & 0.04 & 0.09 & 0.12 & 0.05 & 0.02 & 0.03 & 0.05 & 0.01 & 0.35 & 0.20 & 0.02 & 0.03 & 0.03 & 0.001 & 0.03 & 0.001 & \\
\hline p53 & 0.005 & -0.08 & 0.001 & -0.10 & -0.07 & 0.06 & -0.04 & 0.03 & -0.07 & -0.10 & -0.31 & -0.04 & 0.067 & 0.29 & 0.27 & 0.46 & 0.37 & 0.77 & 0.63 \\
\hline
\end{tabular}




\subsubsection{Discussion}

In the present study, there was significant influence of solar radiation on BGT, AT, $\mathrm{RH}$, and $\mathrm{THI}$; however, is necessary to consider the heating during the day and the cooling during the night for the analysis of the environmental conditions that animals are exposed to in order to understand the physiological responses to heat stress (WEST et al., 2003). In the present study, the unfavorable AT was observed from 12:00 to 15:00 $\mathrm{h}$ because during this period the AT was above the maximum comfortable temperature for goats, which was previously reported as between $20^{\circ} \mathrm{C}$ and $30^{\circ} \mathrm{C}$ (BRASIL et al., 2000; PEREIRA et al., 2011; RIBEIRO et al., 2016). In contrast, $\mathrm{RH}$ was low between 12:00 and 15:00 $\mathrm{h}$ when compared to the other hours of the day. Although AT and $\mathrm{RH}$ show different behaviors between 12:00 and 15:00 $\mathrm{h}$, the THI was higher than 80 during the same period, indicating an alert condition for the goats (SILANIKOVE; KOLUMAN, 2015).

Therefore, the mean RF values of $49.47 \pm 4.32$, $182.4 \pm 11.1$, and $81.87 \pm 7.75$ bpm at 06:00, 13:00, and 18:00 h, respectively, show that the experimental goats were in low, severe, and high heat stress, respectively (SILANIKOVE, 2000). In fact, solar radiation at 13:00 $\mathrm{h}$ increased the $\mathrm{RF}$ of the experimental goats and this physiological mechanism was induced by environmental heat change, in accordance with other studies (BRASIL et al., 2000; RIBEIRO et al., 2016). However, at 18:00 h, the $\mathrm{RF}$ remained high, showing the limit of evaporative mechanisms to dissipate heat when AT is moderate but $\mathrm{RH}$ is high (MAIA et al., 2016). In fact, our results confirm that both AT and $\mathrm{RH}$ are related to the effectiveness of the physiological responses of experimental goats to deal with the subtropical climate.

The RT in the present study was significantly higher at $13: 00 \mathrm{~h}\left(39.6^{\circ} \mathrm{C}\right)$ than at the other times; however, the increase of RF and the climate variations promoted the reduced $\mathrm{RT}$ from 13:00 to 18:00 $\mathrm{h}$. Indeed, the relation between $\mathrm{RT}, \mathrm{RF}$, and the climatic profile during the day and night permitted the experimental goats to have a lower RT at 06:00 h. The RT means observed in the present study were considered as normal for the goats (BRASIL et al., 2000; RIBEIRO et al., 2016), suggesting that experimental goats effectively maintained their RT. The RT is a good metric to understand the animal's adaptability to heat stress (PEREIRA et al., 2011; SILANIKOVE, 2000b). However, in the present study, the solar radiation increased 
the RT of Saanen goats by $1.34^{\circ} \mathrm{C}$, showing that the solar radiation we observed was similar to that of other studies concerning heat stress (BRASIL et al., 2000; HAMZAOUI et al., 2013; Al-SAMAWI et al., 2014; RIBEIRO et al., 2016). As these last studies showed increases from 1.2 to $1.57^{\circ} \mathrm{C}$ in $\mathrm{RT}$, it is possible to assume that solar radiation caused acute heat stress in the experimental goats.

The different body temperature measurements are important to understand the welfare and adaptability of animals to stressful environments (PEREIRA et al., 2011; SILANIKOVE, 2000b). In this context, RT is a gold standard; conversely, other superficial temperatures, including DT, TT, OT, and MT are important to study the effect of solar radiation and were all positively correlated with RT. Considering the importance of the mammary gland to a dairy animal, it is interesting to study the effect of heat stress on MT. Furthermore, the difference between these measures allows us to understand the dynamics of heat loss (BERMAN, 2003). In this context, infrared thermography is a non-invasive tool that allows us to study superficial temperatures (KOTRBA et al., 2007; STEWART et al., 2008; STUBSJØEN et al., 2009; MARTELLO et al., 2016). In the present study, DT measured before, during, and after were significantly influenced by the effect of solar exposition, and DT was more strongly correlated with RT than the other superficial temperatures studied. At the same time, in the present study, there were significant and high correlations between RT and MT and between MT and RF, Cort, T4, Bax, and Bcl-2. Consequently, the use of infrared thermography seems an interesting alternative to study the dynamics of heat loss during lactation; however, further studies are necessary to understand these relations.

In the present study, the heat stress induced by solar radiation caused a significant increase of Cort and a significant decrease of T4 at 13:00 h; other authors have observed similar effects on Cort and T4 release due to heat stress (AI-SAMAWI et al., 2014; RIBEIRO et al., 2016). Therefore, in vivo, the heat stress significantly changed the expression of HSP60, HSP70, and HSP90 on blood leukocytes. The expression of HSP60 and 70 during the period of higher solar radiation can be explained by a cellular mechanism that maintains the conformation of other proteins on the cell, preventing their denaturation and aggregation (DESHAIES et al., 1988; SONNA et al., 2002). Other authors that worked with goats in different seasons also observed a significant effect of heat stress on HSP90, HSP70, and HSP60 (DANGI 
et al., 2012, 2014). In these context, it is possible to argue that different HSPs are expressed to protect the cells during the different heat challenges.

Comparing the in vitro $38^{\circ} \mathrm{C}$ and $40^{\circ} \mathrm{C}$ treatments, there was a very significant difference in the expression of the target genes. In the present study, when leukocytes were maintained in vitro at $40^{\circ} \mathrm{C}$ for three hours, we observed a significant expression of the HSP60, 70, and 90 genes. Indeed, the highest overexpression in the in vitro experiment was measured for the HSP70 gene; several authors have suggested that HSP70 is the most important HSP to study in the field of heat stress (ZULKIFLI et al., 2010; MISHRA et al., 2011; DEB et al., 2013; ROMERO et al., 2013; MOHANARAO et al., 2014).

In vivo, there was no effect of solar radiation exposure on the expression of the $\mathrm{Bax}, \mathrm{Bcl}-2$, or p53 genes, nor on the relation between the Bcl-2 and Bax genes. However, the solar radiation influenced the expression of HSP60 and 70 genes, suggesting that these genes had a protective function during heat stress. In another way, the blood leukocytes exposed to $40^{\circ} \mathrm{C}$ in vitro increased the expression of p53 (pro-apoptotic protein), Bcl-2 (anti-apoptotic protein), and the relation between the $\mathrm{Bcl}-2$ and Bax genes due to higher $\mathrm{Bcl}-2$ expression and maintenance of Bax expression. Similar results concerning the p53 gene and other apoptotic proteins were observed by other authors that worked with heat stress (CHEN; CHUANG, 1999; GU et al., 2014). In contrast to our results, other authors (DU et al., 2008) reported that mammary cells submitted to $40^{\circ} \mathrm{C}$ for $3 \mathrm{~h}$ had decreased $\mathrm{Bcl}-2$ expression and increased Bax expression. It is important to note that different cell models were used in previous studies and the effect of heat stress on different cells can explain this contrast. 


\subsection{Conclusion}

Finally, in vivo, the solar radiation exposure caused acute heat stress, punctual Cort release, and expression of HSP60 and HSP70 in dry Saanen goats, changing their physiological, hormonal, and cellular responses. However, the increased RF and decreased T4 were related to the homeothermy of the experimental goats. In vitro, the $40^{\circ} \mathrm{C}$ treatment caused a significant increase in the expression of the p53 (pro-apoptotic protein) and Bcl-2 (anti-apoptotic protein) genes and an overexpression of the HSP60, HSP70, and HSP90 genes, suggesting that the HSP genes have protective functions. However, further studies are necessary to understand the physiological and cellular responses to heat stress. 


\section{References}

AL-SAMAWI, K. A.; AL-HASSAN, M. J.; SWELUM, A. A. Thermoregulation of female aardi goats exposed to environmental heat stress in Saudi Arabia. Indian Journal of Animal Research, v. 48, n. 4, p. 344, 2014.

ALEJANDRO, M. et al. Infrared thermography as a tool to determine teat tissue changes caused by machine milking in Murciano-Granadina goats. Livestock Science, v. 160, p. 178-185, 2014.

ANDERSON, B. E. Regulação da temperatura e fisiologia ambiental. In: KOOGAN, G. (Ed.). Fisiologia dos Animais Domésticos. 10 ed. Rio de Janeiro: Guanabara Koogan, p. 623-629, 1988.

BAÑUELOS-VALENZUELA, R.; SÁNCHEZ-RODRÍGUEZ, S. H. La proteína de estrés calórico Hsp70 funciona como un indicador de adaptación de los bovinos a las zonas áridas. Revista Electrónica de Veterinaria, v. 6, p. 1-18, 2005.

BERMAN, A. Effects of body surface area estimates on predicted energy requirements and heat Stress. Journal of Dairy Science, v. 86, n. 11, p. 36053610, 2003.

BERNABUCCI, U. et al. Metabolic and hormonal acclimation to heat stress in domesticated ruminants. Animal, v. 4, p. 1167-1183, 2010.

BIANCA, W.; KUNZ, P. Physiological reactions of three breeds of goats to cold, heat and high altitude. Livestock Production Science, v. 5, n. 1, p. 57-69, 1978.

BRASIL, L. H. A. et al. A. Efeitos do estresse térmico sobre a produção, composição química do leite e respostas termorreguladoras de cabras da raça Alpina. Revista Brasileira de Zootecnia, v. 29, n. 6, p. 1632-1641, 2000.

CASTRO-COSTA A. et al. Using infrared thermography for detecting intramammary infections under practical and E. coli O55:B5 endotoxin challenge conditions in dairy ewes. In: 64th Annual Meeting of the European Federation of Animal Science,

Anais... Nantes, França, 2013. 
CASTRO-COSTA, A. et al. Thermographic variation of the udder of dairy ewes in early lactation and following an Escherichia Coli endotoxin intramammary challenge in late lactation. Journal of Dairy Science, v. 97, n. 3, p. 1377-1387, 2014.

CHURCH, J. S.; COOK, N. J.; SCHAEFER, A. L. Recent applications of infrared thermography for animal welfare and veterinary research: everything from chicks to elephants. In: InfraMation, Anais... 2009.

DANGI, S. S. et al. Expression profile of HSP genes during different seasons in goats (Capra hircus). Tropical Animal Health and Production, v. 44, n. 8, p. 1905-12, 2012.

DEB, R. et al. Effect of heat stress on the expression profile of HSP90 among Sahiwal (Bos Indicus) and Frieswal (Bos Indicus $\times$ Bos Taurus) breed of cattle: A comparative study. Gene, v. 536, n. 2, p. 435-440, 2013.

GEBREMEDHIN, K. G. et al. Sweating rate of dairy cows under shade and sunny. In: ASABE 100th Annual International Meeting Sponsored by ASAE, 074083, Anais... 2007.

GU, Z. T. et al. Heat stress induces apoptosis through transcription-independent p53mediated mitochondrial pathways in human umbilical vein endothelial cell. Scientific Reports, v. 4, p. 4469, 2014.

GUERRIERO, V. J.; RAYNES, D. A. Synthesis of heat stress proteins in lymphocytes from livestock, Journal of Animal Science, v. 68, p. 2779-2783, 1990.

HAMZAOUI, S. et al. Physiological responses and lactational performances of latelactation dairy goats under heat stress conditions. Journal of Dairy Science, v. 96, n. 10, p. 6355-6365, 2013.

HARTL, F. U.; BRACHER, A.; HAYER-HARTL, M. Molecular chaperones in protein folding and proteostasis. Nature, v. 475, n. 7356, p. 324-332, 2011.

$\mathrm{HU}, \mathrm{H}$. et al. Heat-induced apoptosis and gene expression in bovine mammary epithelial cells. Animal Production Science, v. 56, n. 5, p. 918, 2016. 
JOHNSON, S. I.; MCMICHAEL, M.; WHITE, G. Heatstroke in small animal medicine: A clinical practice review. Journal of Veterinary Emergency and Critical Care, v. 16, n. 2, p. 112-119, 2006.

KISHORE, A. et al. Peripheral Blood Mononuclear Cells: a potential cellular system to understand differential heat shock response across native cattle (bos indicus), exotic cattle (bos taurus), and riverine buffaloes (Bubalus bubalis) of India. Cell Stress \& Chaperones, v. 19, n. 5, p. 613-621, 2013.

KONESWARAN, G.; NIERENBERG, D., Global farm animal production and global warming: impacting and mitigating, Climate Change, Environmental Health Perspectives, v. 116, n. 5, p. 578- 582, 2008.

KOTRBA, R. et al. Comparison between the coat temperature of the eland and dairy cattle by infrared thermography. Journal of Thermal Biology, v. 32, n. 6, p. 355359, 2007.

LANNEAU, D. et al. Apoptosis versus cell differentiation: role of heat shock proteins HSP90, HSP70 and HSP27. Prion, v. 1, n. 1, p. 53-60, 2007.

LIVAK, K. J.; SCHMITTGEN, T. D. Analysis of relative gene expression data using real-time quantitative PCR and the $2^{(- \text {Delta Delta } C(T))}$ Method. Methods, v. 25, n. 4, p. 402-408, 2001.

MAIA, A. S. C. et al. Thermoregulatory responses of goats in hot environments. International Journal of Biometeorology, v. 59, n. 8, p. 1025-1033, 2015.

MAIA, A. S. C. et al. Thermal equilibrium of goats. Journal of Thermal Biology, v. 58, p. 43-49, 2016.

MARTELLO, L. S. et al. Infrared thermography as a tool to evaluate body surface temperature and its relationship with feed efficiency in Bos indicus cattle in tropical conditions. International Journal of Biometeorology, v. 60, n. 1, p. 173-181, 2016.

MCMANUS, C. et al., Heat tolerance in naturalized brazilian cattle breeds. Livestock Science, v. 120, n. 3, p. 256-264, 2009. 
MCMICHAEL, A. J. et al. Food, livestock production, energy, climate change, and health. Lancet, v. 370, n. 9594, p. 1253-63, 2007.

MISHRA, A. et al. Influence of induced heat stress on HSP70 in buffalo lymphocytes. Journal of Animal Physiology and Animal Nutrition, v. 95, n. 4, p. 540-544, 2011.

MOHANARAO, G. J. et al. HSP70 Family genes and HSP27 expression in response to heat and cold stress in vitro in peripheral blood mononuclear cells of goat (Capra Hircus). Small Ruminant Research, v. 116, n. 2-3, p. 94-99, 2014.

OHTSUBO, T. et al. Acidic environment modifies heat- or radiation-induced apoptosis in human maxillary cancer cells. International Journal of Radiation Oncology, Biology, Physics, v. 49, n. 5, p. 1391-1398, 2001.

PAULA-LOPES, F. F. et al. Genetic divergence in cellular resistance to heat shock in cattle: differences between breeds developed in temperate versus hot climates in responses of preimplantation embryos, reproductive tract tissues and lymphocytes to increased culture temperatures. Reproduction, v. 125, n. 2, p. 285-294, 2003.

PEREIRA, A. M. F. et al. Evaporative heat loss in bos taurus: do different cattle breeds cope with heat stress in the same way? Journal of Thermal Biology, v. 45, p. 87-95, 2014.

PEREIRA, G. M. et al. Avaliação do comportamento fisiológico de caprinos da raça Saanen no semiárido paraibano. Revista Verde de Agroecologia e

Desenvolvimento Sustentável, v. 6, n. 1, p. 83-88, 2011.

RIBEIRO, N. L. et al. Adaptive profile of garfagnina goat breed assessed through physiological, haematological, biochemical and hormonal parameters. Small Ruminant Research, v. 144, p. 236-241, 2016.

ROMERO, R. D. et al. Differences in body temperature, cell viability, and HSP70 concentrations between Pelibuey and Suffolk sheep under heat stress. Tropical Animal Health and Production, v. 45, n. 8, p. 1691-1696, 2013.

SATHIYABARATHI, M. et al. Infrared Thermography: a potential noninvasive tool to monitor udder health status in dairy cows. Veterinary World, v. 9, n. 10, p. 10751081, 2016. 
SILANIKOVE, N. The physiological basis of adaptation in goats to harsh environments. Small Ruminant Research, v. 35, n. 3, p. 181-193, 2000.

SILANIKOVE, N.; KOLUMAN, D. N. Impact of climate change on the dairy industry in temperate zones: predications on the overall negative impact and on the positive role of dairy goats in adaptation to earth warming. Small Ruminant Research, v. 123, n. 1, p. 27-34, 2015.

SILVA, G. de A. et al. Efeito da época do ano e período do dia sobre os parâmetros fisiológicos de reprodutores caprinos no semi-árido paraibano. Revista Brasileira de Engenharia Agrícola e Ambiental, v. 10, n. 4, p. 903-909, 2006.

SONNA, L. A. et al. Invited Review: Effects of heat and cold stress on mammalian gene expression. Journal of Applied Physiology, v. 92, n. 4, p. 1725-1742, 2002.

STEWART, M. et al. Eye temperature and heart rate variability of calves disbudded with or without local anesthetic. Physiology \& Behavior, v. 93, n. 4, p. 789-797, 2008.

STUBSJØEN, S. M. et al. Exploring non-invasive methods to assess pain in sheep. Physiology \& Behavior, v. 98, n. 5, p. 640-648, 2009.

THOM, E. C. Measuring the need for air conditioning. Air Conditioning, Heating and Ventilation, v. 53, n. 8, p. 68-70, 1958.

WESCHENFELDER, A. V. et al. Use of infrared ocular thermography to assess physiological conditions of pigs prior to slaughter and predict pork quality variation. Meat Science, v. 95, n. 3, p. 616-620, 2013.

WEST, J. W.; MULLINIX, B. G.; BERNARD, J. K. Effects of hot, humid weather on milk temperature, dry matter intake, and milk yield of lactating dairy cows. Journal of Dairy Science, v. 86, n. 1, p. 232-242, 2003.

ZULKIFLI, I. et al. A note on heat shock protein 70 expression in goats subjected to road transportation under hot, humid tropical conditions. Animal, v. 4, p. 973, 2010. 


\title{
3. PHYSIOLOGICAL AND HEAT SHOCK RESPONSES OF SAANEN GOATS DURING AND AFTER LONG-TERM HEAT STRESS AT FINAL GESTATION
}

\begin{abstract}
The long exposition to heat in the current climate changes can negatively affects animals' performance and productivity, particularly when associated with gestation. Indeed, little is known about the biological responses during long-term heat stress even at final gestation period of dairy goats. In this context, physiological and cellular responses of Saanen goats submitted to heat stress $\left(37^{\circ} \mathrm{C}\right.$ from $10: 00$ to $\left.16: 00 \mathrm{~h}\right)$ were investigated. The experiment period occurred from 60 days' pre-partum to 60 days' post-partum. At final gestation, forty-six pregnant Saanen goats were randomly assigned in control treatment (CT; thermal neutral conditions) and heat stress treatment (HS; climatic chamber). After partum, all HS goats were maintained in thermal neutral conditions. Rectal, dorsal, mammary temperatures, respiratory frequency and cortisol before, during and after heat challenge were measured. Gene expression of HSP60, HSP70 and HSP90 were evaluated on peripheral blood mononuclear cells. The HS goats significantly mobilized the increase of respiratory frequency to lose heat. The long-term heat stress promoted the increase of cortisol release on day -15 pre-parturition $(P<0.05)$ that was still higher on day 15 postparturition. At cellular level, the HSP70 was the highest expressed during and after heat challenge, with more transcripts on day 15 post-parturition for HS. In conclusion, our findings suggest that the respiratory frequency and the HSP70 are reliable biomarkers to evaluate thermal comfort and thermo-tolerance of Saanen goats on long-term heat stress.
\end{abstract}

Keywords: acclimation; cortisol; HSP70; PBMC; rectal temperature; thermal tolerance. 


\section{Resumo (Portuguese)}

A longa exposição ao calor nas mudanças climáticas atuais pode afetar negativamente $\mathrm{o}$ desempenho e a produtividade dos animais, particularmente quando associados à gestação. De fato, pouco se sabe sobre as respostas biológicas durante o estresse de calor a longo prazo, mesmo no período final de gestação das cabras leiteiras. Neste contexto, foram investigadas as respostas fisiológicas e celulares de cabras da raça Saanen submetidas ao estresse por calor (37 ${ }^{\circ} \mathrm{C}$ das 10:00 às 16: 00h). O período experimental aconteceu de 60 dias antes do parto até os 60 dias após o parto. Na fase final de gestação, quarenta e seis cabras da raça Saanen foram aleatoriamente distribuídas nos tratamentos controle (termoneutralidade) e estresse térmico (câmara climática). Após o parto, todas as cabras do estresse térmico foram mantidas em condições de termoneutralidade. A temperatura retal, dorsal, mamária, frequência respiratória e cortisol foram medidas antes, durante e após o desafio com calor. A expressão gênica da HSP60, HSP70 e HSP90 foi avaliada em células mononucleares do sangue periférico. As cabras mantidas sob calor aumentaram a frequência respiratória para aumentar a perda de calor. $O$ estresse por calor a longo prazo promoveu o aumento da liberação de cortisol no dia 15 pré-parto $(P<0,05)$, que foi ainda maior no dia 15 pós-parto. $A$ nível celular, a HSP70 foi a mais expressa durante e após o desafio com calor, com mais transcritos no dia 15 pós-parto para as cabras sob estresse. Em conclusão, nossos achados sugerem que a frequência respiratória e a HSP70 são biomarcadores confiáveis para avaliar o conforto térmico e a termotolerância de cabras Saanen sob estresse térmico a longo prazo.

Palavras-chave: aclimatação; cortisol; HSP70; PBMC; temperatura retal; termotolerância. 


\subsection{Introduction}

Climate changes are undeniable and unprecedented, the ocean and atmosphere have warmed, sea level has risen, the greenhouse gases increased and the quantities of snow and ice reduced (IPCC, 2013). Besides, population grows and also the necessity to improve livestock and agriculture productivity to supply food demand (ROJAS-DOWNING et al., 2017). Climatic changes worsen the performance of animals and in tropical and subtropical regions this impact is more pronounced because of the exposition to high air temperature and humidity for long periods that negatively impact the heat exchange to environment (THORNTON et al., 2009; DURAIRAJANAYAGAM; AGARWAL; ONG, 2015; SILANIKOVE; KOLUMAN, 2015).

The increase of air temperature affects livestock by changing water and forage availability, production, reproduction and health traits (ROJAS-DOWNING et al., 2017). Goats' production was one of the first exploited by humans, being a highly suitable specie for harsh environments and their production has gained visibility because of milk and cheese products (BOYAZOGLU; HATZIMINAOGLOU; MORAND-FEHR, 2005; HOODA; UPADHYAY, 2014). Therefore, heat stress is on attention in many fields of dairy research, including dairy goats (GEBREGEZIABHEAR, 2015; NARAYAN; SAWYER; PARISELLA, 2018; SALAMA et al., 2014; SILANIKOVE; KOLUMAN, 2015).

Even with better adaptation to harsh environments, goats mobilize thermoregulatory mechanisms to overcome heat stress. Heat acclimation results in systemic and cellular changes in order to reduce the effects of heat, such as higher skin blood flow and sweating, lower body temperature, improved body fluid, electrolyte balance and increase of heat shock proteins (HSPs) (AMORIM et al., 2015). The responses to heat stress initially occur in an acute phase with the exposition to heat from hours to days and the chronic phase from days to months (BHARATI et al., 2017). At cellular level, cells synthetize and accumulate HSPs as an adaptation mechanism to protect cells from damage that allows the organism to survive to a subsequent stressor (MOSELEY, 1997). The HSPs are important molecules that stabilize other proteins acting in the folding, refolding, transport, as well as aggregates dissolution (MACARIO; MACARIO, 2007). 
During gestation, goats pass to abrupt changes that occur due to rapid fetal development, extensive mammary gland growth and endocrine induction of lactation (CAPUCO et al., 1997, ADIN et al., 2009). The effects of HS are worsen when combined with gestation, peculiarly at final third (BELL et al., 1989; BROWN et al., 1977; TAO et al., 2011). The majority of findings related to thermoregulatory responses of small ruminants were done in short-term exposition to heat stress with non-pregnant animals (BIANCA; KUNZ, 1978; HAMZAOUI et al., 2013; MAIA et al., 2015; RIBEIRO et al., 2016). For this reason, the present study aimed to investigate the physiological and cellular responses of Saanen goats when submitted to heat stress at final gestation.

\subsubsection{Material and methods}

Experimental site and ethical approval

All animal practices were in accordance with the ethical procedures for animals and were approved by the local ethic committee receiving the certification number: 3709280316. The study was carried out from May to September at the Laboratory of Animal Physiology, Faculty of Animal Science and Food Engineering (FZEA), University of São Paulo (USP), Pirassununga (21 $58^{\prime}$ 'S and $47^{\circ} 26^{\prime \prime} \mathrm{W}$ ), Brazil. The local climate is subtropical humid (Köeppen-Geiger classification) with annual rainfall of $1238 \mathrm{~mm}$ per year.

Weather data

Air temperature $(\mathrm{AT})$ and relative humidity $(\mathrm{RH})$ were recorded at each 15 minutes by data-loggers (Onset $\mathrm{HOBO}$, Cape Cod, MA, USA). The temperature and humidity index (THI) was calculated according to the formula proposed by Buffington et al. (1983) $\mathrm{THI}=0.8 \mathrm{AT}+\mathrm{RH}(\mathrm{AT}-14.3) / 100+46.3$, where $\mathrm{AT}\left({ }^{\circ} \mathrm{C}\right)$ is air temperature and $\mathrm{RH}(\%)$ is the relative humidity. The $\mathrm{THI}$ values was classified for goats in: normal when lower than $80,80 \leq$ alert $<85,85 \leq$ danger $<90$, and extreme 
when $\geq 90$ (SILANIKOVE; KOLUMAN, 2015). The weather data at 7:00, 15:00 and 21:00 $\mathrm{h}$ pre-partum and post-partum is presented on Table 1.

Experimental design, housing and nutrition

Forty-six healthy Saanen goats with weight of $55 \pm 12 \mathrm{~kg}$ and body condition score of $2.5 \pm 0.5$ were used in the experiment. Free access to water, food and mineral salt ad libitum was provided. The total diet was compound by corn silage, hay and mixed grains at 60:40 ratios, offered twice a day. The concentrate supplementation was formulated taking in account the animals' category to provide $100 \%$ of the dietary needs (NRC, 2007) and the feed intake was adjusted daily with $10 \%$ of leftovers.

Experimental goats were randomly assigned in the control $(n=23$; CT; shaded area) and heat stress ( $n=23$; HS; climatic chamber) treatments. The experiment period went from 60 days' pre-partum to 60 days' post-partum. Pregnancy and the number of fetus were previous confirmed by ultrasound. The CT goats were housed in a shaded and well ventilated pen. From -60 to -45 days' pre-partum, both treatments passed by an adaptation period, for habituation to the new environment and social hierarchy familiarization. During 45 days' pre-partum, the climatic chamber was set up to reach maximum air temperature of $37^{\circ} \mathrm{C}$ from $10: 00$ to $16: 00 \mathrm{~h}$, however the $\mathrm{RH}$ was not manipulated. After parturition, the HS goats were housed in the same conditions as the CT group. 
Table 1. Mean, minimum and maximum or air temperature (AT), relative humidity $(\mathrm{RH})$, temperature humidity index (THI) prepartum and post-partum.

\begin{tabular}{|c|c|c|c|c|c|c|c|c|c|c|}
\hline & \multirow[b]{3}{*}{ Hour } & \multicolumn{6}{|c|}{ Pre-partum } & \multirow{2}{*}{\multicolumn{3}{|c|}{$\begin{array}{c}\text { Post-partum } \\
\text { CT/HS }\end{array}$}} \\
\hline & & \multicolumn{3}{|c|}{ CT } & \multicolumn{3}{|c|}{ HS } & & & \\
\hline & & Mean & Minimum & Maximum & Mean & Minimum & Maximum & Mean & Minimum & Maximum \\
\hline & $7: 00 \mathrm{~h}$ & 14.09 & 12.3 & 17.16 & 20.67 & 17.14 & 22.88 & 14.47 & 5.53 & 25.77 \\
\hline \multirow[t]{3}{*}{ AT $\left({ }^{\circ} \mathrm{C}\right)$} & $15: 00 \mathrm{~h}$ & 24.07 & 19.57 & 26.34 & 34.56 & 27.78 & 38.69 & 28.06 & 19.96 & 35.94 \\
\hline & $21: 00 \mathrm{~h}$ & 16.15 & 13.17 & 19.67 & 23.8 & 21.33 & 25.17 & 18.46 & 12.46 & 34.6 \\
\hline & $7: 00 \mathrm{~h}$ & 20.14 & 0 & 79.92 & 78.86 & 70.43 & 89.38 & 32.46 & 0 & 79.98 \\
\hline \multirow[t]{3}{*}{ RH (\%) } & $15: 00 \mathrm{~h}$ & 63.16 & 50.75 & 78.42 & 53.07 & 24.27 & 64.43 & 42.35 & 30.26 & 72.25 \\
\hline & $21: 00 \mathrm{~h}$ & 56.78 & 13.33 & 78.5 & 66.52 & 41.17 & 76.2 & 67.41 & 3 & 76.33 \\
\hline & $7: 00 \mathrm{~h}$ & 57.76 & 55.78 & 62.31 & 68.07 & 63.38 & 71.4 & 48.63 & 37.24 & 70.76 \\
\hline \multirow[t]{2}{*}{ THI } & $15: 00 \mathrm{~h}$ & 71.66 & 65.51 & 74.47 & 85.44 & 76.47 & 91.81 & 66.16 & 58.47 & 72.39 \\
\hline & $21: 00 \mathrm{~h}$ & 60.12 & 56.08 & 66.23 & 71.75 & 66.34 & 74.82 & 59.14 & 49.01 & 69.98 \\
\hline
\end{tabular}


Physiological measurements and blood sampling

The rectal $(\mathrm{RT})$, dorsal (DT), mammary (MT) temperatures and respiratory frequency $(\mathrm{RF})$ were taken at 7:00 h, 15:00 $\mathrm{h}$ and 21:00 $\mathrm{h}$ before (-60 pre-partum), during (-45, -30, -15 pre-partum) and after heat challenge (15, 30, 45 and 60 postpartum). The RT was measured using clinical thermometer with a precision of \pm $0.1^{\circ} \mathrm{C}$ and $\mathrm{DT}$ and $\mathrm{MT}$ with an infrared thermometer with a precision of $\pm 0.2^{\circ} \mathrm{C}$. RF was evaluated with a stethoscope placed on ribs space to obtain the breath movements per minute (bpm).

Blood samples were collected by jugular vein puncture in heparin tubes under sterile conditions to obtain the plasma for cortisol analysis at 7:00 $\mathrm{h}$ on day -60 (before), at 15:00 $\mathrm{h}$ on days $-45,-30$ and -15 (during) and after, at 15:00 $\mathrm{h}$ on days 15, 30 and 45. Cortisol (Cort) was measured by immunoassay kits (Monobind Inc. Lake Forest. CA. USA) with sensitivity of $0.25 \mu \mathrm{g} / \mathrm{dl}$. The intra- and inter-assay coefficients of variation were $2.8 \%$ and $6.5 \%$, respectively. All concentrations were detected using enzyme immunoassay (EIA) microplate reader (Labsystem Multiskan MS. MTX Labsystems. INC. Vienna. VA. USA).

HSPs gene expression

The PBMCs were used as a cell model to study heat shock response as described in the literature (McCLUNG et al., 2008; DEB et al., 2013; KISHORE et al., 2014; MOHANARAO et al., 2014). On day -15 (during) and on day 15 (after heat challenge), at 7:00 $\mathrm{h}$, blood samples were randomly taken from fourteen goats in EDTA tubes (seven animals per group). The blood was centrifuged at $1.500 \mathrm{~g}$ for 20 minutes at $24^{\circ} \mathrm{C}$, the upper leucocyte layer transfered to a microtube and successively washed with of hemolysis solution $(300 \mathrm{ml}$ of ultrapure water, $54.8 \mathrm{~g}$ of sucralose, $6 \mathrm{ml}$ of Tris- $\mathrm{HCl}, 2.5 \mathrm{ml}$ of $\mathrm{MgCl} 2,5 \mathrm{ml}$ of Triton 1\%). The pellet containing the PBMCs was maintained at $-80^{\circ} \mathrm{C}$ until the RNA extraction.

RNA extraction and purification was performed with Purelink RNA Mini Kit (Invitrogen, Carlsbad, CA, USA). The concentrations were determinated on Qubit ${ }^{\circledR}$ 2.0 Fluorometric Quantification (Thermo Fisher Scientific. Wilmington. DE. USA). The 
RNA obtained was treated with RNase-Free DNase (Promega, Madison, WI, USA) to exclude genomic DNA contaminations. The RNA was reverse transcribed into cDNA using GoScript TM Reverse Transcriptase kit (Promega, Madison, WI, USA). The cDNA obtained was preserved in $-20^{\circ} \mathrm{C}$ until qPCR analysis.

The $\mathrm{qPCR}$ was executed in a PCR-RT equipment (Invitrogen, Carlsbad, CA), using 96 well plates (Invitrogen, Carlsbad, CA, USA) with SYBR® Green (Invitrogen, Carlsbad, CA, USA). Each reaction had a total volume of $20 \mu \mathrm{L}$, the mix reaction was compound of $1 \mu \mathrm{l} \mathrm{cDNA}$ (mean concentration of $10 \mathrm{ng} / \mu \mathrm{l}$ ), $10 \mu \mathrm{l}$ of Mix SYBR ${ }$ Green, $0.4 \mu \mathrm{M}$ primer pair and $8.2 \mu \mathrm{l}$ of ultrapure water. A control reaction (NTC) was included in each essay to detect contaminations. GAPDH and Ubiquitin were used as housekeeping genes and HSP60, HSP70 and HSP90 as target genes (Table 2). The samples were incubated at $95^{\circ} \mathrm{C}$ for 10 minutes, followed by 40 cycles with temperature increase and separation of double stranded (95 ${ }^{\circ} \mathrm{C}$ for 15 seconds), annealing, primers bind to its homologous region in the cDNA (60 ${ }^{\circ} \mathrm{C}$ for 1 minute); dissociation curve. Relative gene expression was done using the Livak and Schmittgen (2001) method. For each set of primers, the PCR efficiency was close to $100 \%$ and specific products were checked by melt curve analysis and for appropriate size by $1.5 \%$ agarose gel electrophoresis.

Table 2. Primer sequences and amplicon size of each gene analyzed in goat's peripheral blood mononuclear cells by quantitative real time PCR.

\begin{tabular}{ccccc}
\hline Genes & Primer sequency (F/R) & Amplicon & Reference & $\begin{array}{c}\text { Efficiency } \\
(\%)\end{array}$ \\
\hline HSP60 & 3'ACTGGCTCCTCATCTCACTC5' & 147 & NM_001166609.1 & 109.9 \\
& 5'TGTTCAATAATCACTGTCCTTCC3' & & & \\
HSP70 & 3'GACGACGGCATCTTCAAG5' & 171 & U09861 & 115.3 \\
& 5'GTTCTGGCTGATGTCCTTC3' & & & \\
HSP90 & $\begin{array}{c}\text { 3'GCATTCTCAGTTCATTGGCTATCC5' } \\
\text { 5'GTCCTTCTTCTCTTCCTCCTCTTC3' }\end{array}$ & 190 & NM_001012670.1 & 102.2 \\
GAPDH & 3'GGGTCATCATCTCTGCACCT5' & 181 & NM_001034034.2 & 101.5 \\
& 5'GGTCATAAGTCCCTCCACGA3' & & & \\
UBC & 3'-ATGCAGATCTTTGTGAAGAC-5' & 189 & NM_001206307.1 & 100.6 \\
& 5'-CTTCTGGATGTTGTAGTC-3' & & & \\
\hline
\end{tabular}


Statistical Analysis

Data were analyzed using the Statistical Analysis System (SAS, 2008). The normality was confirmed using the Shapiro-Wilk test. The analysis of physiological data was conducted separately, during and after heat challenge, due to the physiological differences in each phase. Weather, body temperatures, respiratory frequency, cortisol release were subjected to an analysis of variance by the MIXED procedure of SAS. In the model was considered the fixed effects of treatment and random effect of day and hour. The HSPs gene expression was done with analysis of variance by GLM procedure, in which was considered the fixed effects of treatment during and after heat challenge. Pearson correlations were considered to estimate the relations between weather data, body temperatures, respiratory frequency, cortisol, HSPs responses with PROC CORR procedure. When there was a significant effect, the means were compared using Fisher test. Significance was defined as $\mathrm{P} \leq 0.05$.

\subsubsection{Results}

Heat challenge

In Table 3 is represented the AT, $\mathrm{RH}$ and $\mathrm{THI}$ during and after heat challenge at 7:00 h, 15:00 $\mathrm{h}$ and 21:00 h. During heat challenge, the AT and THI were significantly higher for HS than CT specially at 15:00 h $(\mathrm{P}<.001)$. The THI during heat challenge was classified as danger and for the other times were considered normal for goats. Inside the climatic chamber, the $\mathrm{RH}$ was significantly higher at 7:00 $\mathrm{h}$ for $\mathrm{HS}$ treatment when compared to CT treatment. After heat challenge, no difference was observed for environmental data, because the animals of both experimental treatments were kept in the same environment with thermal neutral condition. The AT profile before, during and after heat stress imposition are represented in Figure 1. 
Table 3. Means follow by standard error of air temperature (AT), relative humidity $(\mathrm{RH})$ and Temperature Humidity Index (THI) at 7:00, 15:00 and 21:00 hours during heat challenge (pre-partum) and after (post-partum) for heat stress (HS) and control (CT) treatments.

\begin{tabular}{|c|c|c|c|c|c|}
\hline & Variable & Hours & CT & HS & P-value \\
\hline \multirow{9}{*}{ 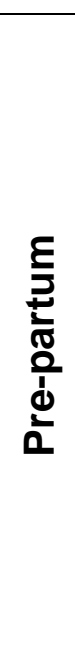 } & \multirow{3}{*}{$\operatorname{AT}\left({ }^{\circ} \mathrm{C}\right)$} & $7: 00 \mathrm{~h}$ & $14.09 \pm 0.14 \mathrm{e}$ & $20.67 \pm 0.15 c$ & \multirow{3}{*}{$<.001$} \\
\hline & & $15: 00 \mathrm{~h}$ & $24.07 \pm 0.19 b$ & $34.56 \pm 0.29 a$ & \\
\hline & & $21: 00 \mathrm{~h}$ & $16.15 \pm 0.18 d$ & $23.80 \pm 0.08 b$ & \\
\hline & \multirow{3}{*}{$\mathrm{RH}(\%)$} & $7: 00 \mathrm{~h}$ & $20.14 \pm 1.42 \mathrm{~d}$ & $78.86 \pm 0.40 \mathrm{a}$ & \multirow{3}{*}{$<.001$} \\
\hline & & $15: 00 \mathrm{~h}$ & $63.16 \pm 0.87 b$ & $53.07 \pm 1.19 \mathrm{c}$ & \\
\hline & & $21: 00 \mathrm{~h}$ & $56.78 \pm 1.79 c$ & $66.52 \pm 1.07 b$ & \\
\hline & \multirow{3}{*}{ THI } & $7: 00 \mathrm{~h}$ & $57.76 \pm 0.14 \mathrm{e}$ & $68.07 \pm 0.21 \mathrm{c}$ & \multirow{3}{*}{$<.001$} \\
\hline & & $15: 00 \mathrm{~h}$ & $71.66 \pm 0.24 b$ & $85.44 \pm 0.36 a$ & \\
\hline & & $21: 00 \mathrm{~h}$ & $60.12 \pm 0.22 \mathrm{~d}$ & $71.75 \pm 0.18 b$ & \\
\hline \multirow{9}{*}{$\begin{array}{l}\text { E } \\
\frac{1}{2} \\
\frac{1}{\pi} \\
\frac{0}{1} \\
\frac{1}{0} \\
0 \\
0\end{array}$} & \multirow{3}{*}{$\operatorname{AT}\left({ }^{\circ} \mathrm{C}\right)$} & $7: 00 \mathrm{~h}$ & $14.47 \pm 0.47$ & $14.52 \pm 0.4$ & \multirow{3}{*}{0.764} \\
\hline & & $15: 00 \mathrm{~h}$ & $28.06 \pm 0.44$ & $28.21 \pm 0.41$ & \\
\hline & & $21: 00 \mathrm{~h}$ & $18.46 \pm 0.44$ & $18.04 \pm 0.35$ & \\
\hline & \multirow{3}{*}{$\mathrm{RH}(\%)$} & $7: 00 \mathrm{~h}$ & $32.46 \pm 2.59$ & $34.29 \pm 2.61$ & \multirow{3}{*}{0.730} \\
\hline & & $15: 00 \mathrm{~h}$ & $42.35 \pm 0.99$ & $41.76 \pm 0.99$ & \\
\hline & & $21: 00 \mathrm{~h}$ & $67.41 \pm 1.55$ & $66.57 \pm 1.67$ & \\
\hline & \multirow{3}{*}{$\mathrm{THI}$} & $7: 00 \mathrm{~h}$ & $48.63 \pm 0.75$ & $49.46 \pm 0.72$ & \multirow{3}{*}{0.575} \\
\hline & & $15: 00 \mathrm{~h}$ & $66.16 \pm 0.48$ & $66.64 \pm 0.48$ & \\
\hline & & $21: 00 \mathrm{~h}$ & $59.14 \pm 0.66$ & $58.68 \pm 0.64$ & \\
\hline
\end{tabular}

${ }^{*}$ Different letters within treatments and times for the same variable represent $P \leq 0.05$. 


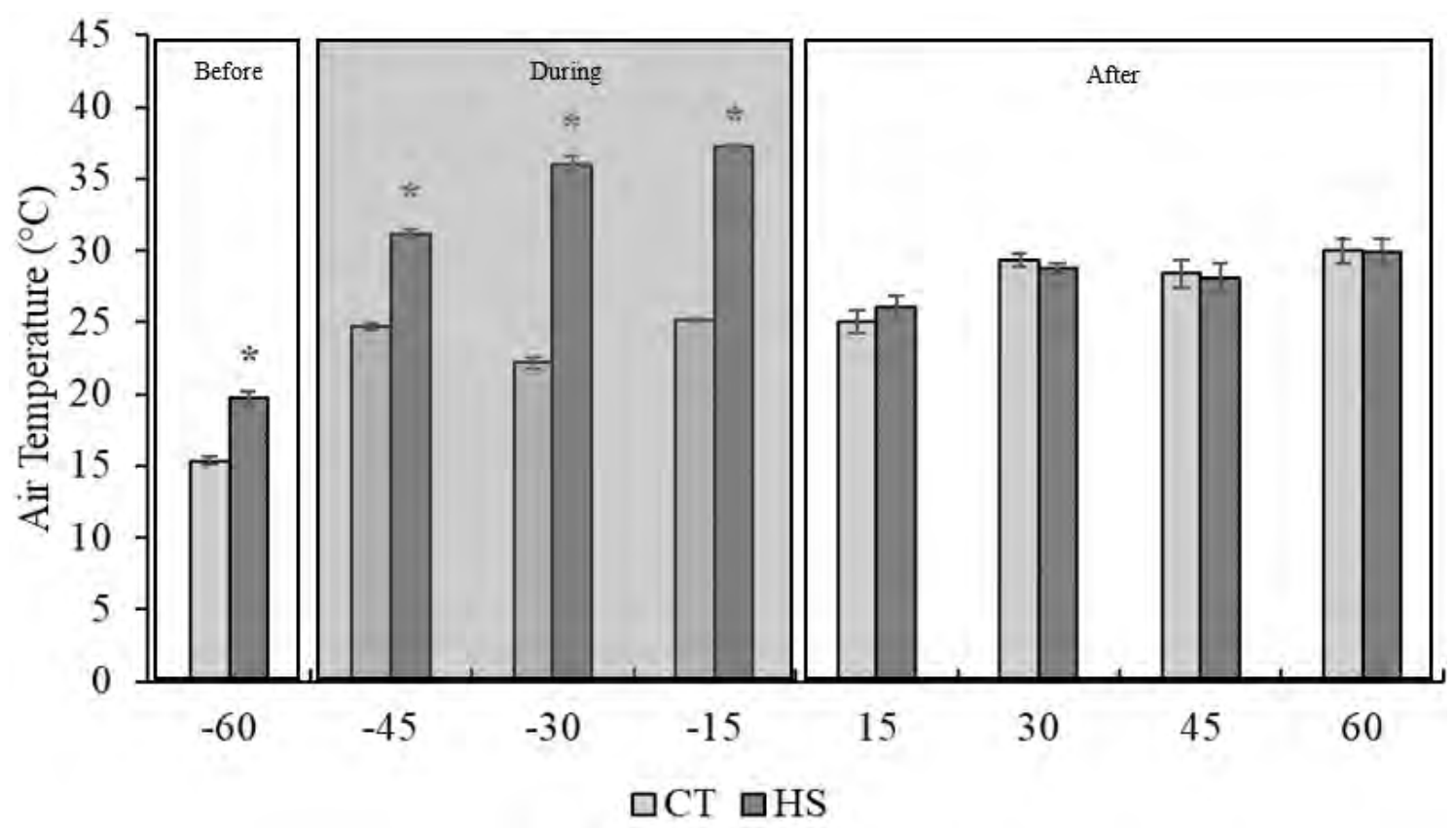

Figure 1. Air temperature before (on day -60), during (on days $-45,-30,-15$ ) and after heat challenge (on days 15, 30, 45 and 60).

${ }^{*} \mathrm{P} \leq 0.05$ within treatments for the same day related to partum

Physiological Responses

During heat challenge, RT, DT, MT and RF were higher at 15:00 $\mathrm{h}$ for HS when compared to CT $(P<0.05)$ (Table 4).

Although, the RT was similar within treatments at 7:00 h, the RF, DT and MT was higher for HS than CT at this time (Table 4). Over time, the physiological variables, RT, DT, MT, RF and Cort before $(7: 00 \mathrm{~h})$. during and after $(15: 00 \mathrm{~h})$ heat challenge are represented on Figure $2(A, B, C, D$ and $E)$, with higher values during heat challenge for HS than $\mathrm{CT}$. After heat challenge, no difference within treatments were observed for RT and RF. Otherwise, DT was higher for HS on day 15 and lower on day 30 , and MT was also lower for HS on day 30 , when compared to CT. Furthermore, the physiological responses pre-parturition were significantly influenced by the number of offspring. Higher values of RT, DT and MT when the mother had twin or triplets were observed (Table 5). When parturition approached, the Cort release increased for both $\mathrm{CT}$ and HS treatments. Besides, the long-term heat stress 
increased cortisol (Cort) release for HS on day -15 pre-partum at 15:00 $\mathrm{h}$. that remains elevated until day 15 post-parturition.

Table 4. Means follow by standard error of rectal temperature (RT), dorsal temperature (DT), mammary temperature (MT) and respiratory frequency (RF) at 7:00, 15:00 and 21:00 hours pre-partum and post-partum for heat stress (HS) and control (CT) treatments.

\begin{tabular}{|c|c|c|c|c|c|}
\hline & Variable & Hours & CT & HS & P-value \\
\hline \multirow{12}{*}{ 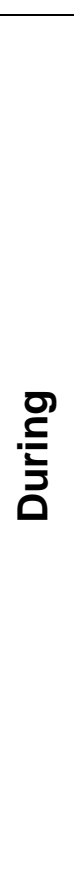 } & & $7: 00 \mathrm{~h}$ & $38.39 \pm 0.03 c$ & $38.48 \pm 0.03 c$ & \\
\hline & $\mathrm{RT}\left({ }^{\circ} \mathrm{C}\right)$ & $15: 00 \mathrm{~h}$ & $38.82 \pm 0.02 b$ & $39.22 \pm 0.03 a$ & $<.001$ \\
\hline & & $21: 00 \mathrm{~h}$ & $38.83 \pm 0.03 b$ & $38.85 \pm 0.03 b$ & \\
\hline & & $7: 00 \mathrm{~h}$ & $24.20 \pm 0.17 f$ & $30.02 \pm 0.13 c$ & \\
\hline & DT $\left({ }^{\circ} \mathrm{C}\right)$ & $15: 00 \mathrm{~h}$ & $29.10 \pm 0.25 d$ & $35.84 \pm 0.13 a$ & 0.013 \\
\hline & & $21: 00 \mathrm{~h}$ & $25.69 \pm 0.21 \mathrm{e}$ & $31.54 \pm 0.16 b$ & \\
\hline & & $7: 00 \mathrm{~h}$ & $30.19 \pm 0.18 f$ & $33.91 \pm 0.16 c$ & \\
\hline & $\mathrm{MT}\left({ }^{\circ} \mathrm{C}\right)$ & $15: 00 \mathrm{~h}$ & $33.35 \pm 0.22 \mathrm{~d}$ & $37.06 \pm 0.10 \mathrm{a}$ & 0.05 \\
\hline & & $21: 00 \mathrm{~h}$ & $31.62 \pm 0.20 \mathrm{e}$ & $34.74 \pm 0.16 b$ & \\
\hline & & $7: 00 \mathrm{~h}$ & $50.99 \pm 1.64 d$ & $63.27 \pm 1.71 c$ & \\
\hline & $\mathrm{RF}(\mathrm{bpm})$ & $15: 00 \mathrm{~h}$ & $84.00 \pm 2.39 b$ & $136.53 \pm 2.85 a$ & $<.001$ \\
\hline & & $21: 00 \mathrm{~h}$ & $70.94 \pm 2.43 c$ & $93.25 \pm 2.62 b$ & \\
\hline \multirow{12}{*}{$\frac{\frac{1}{ \pm}}{\frac{ \pm}{4}}$} & & $7: 00 \mathrm{~h}$ & $38.04 \pm 0.05 c$ & $38.18 \pm 0.05 c$ & \\
\hline & $\mathrm{RT}\left({ }^{\circ} \mathrm{C}\right)$ & $15: 00 \mathrm{~h}$ & $39.05 \pm 0.05 a$ & $39.15 \pm 0.05 a$ & 0.04 \\
\hline & & $21: 00 h$ & $38.78 \pm 0.05 b$ & $38.68 \pm 0.05 b$ & \\
\hline & & $7: 00 \mathrm{~h}$ & $21.7 \pm 0.4 c$ & $22.72 \pm 0.34 c$ & \\
\hline & $\mathrm{DT}\left({ }^{\circ} \mathrm{C}\right)$ & $15: 00 \mathrm{~h}$ & $33.67 \pm 0.39 a$ & $32.94 \pm 0.29 a$ & 0.006 \\
\hline & & $21: 00 h$ & $26.06 \pm 0.29 b$ & $27.37 \pm 0.33 b$ & \\
\hline & & $7: 00 \mathrm{~h}$ & $30.49 \pm 0.33 c$ & $30.18 \pm 0.22 c$ & \\
\hline & $\mathrm{MT}\left({ }^{\circ} \mathrm{C}\right)$ & $15: 00 h$ & $37.11 \pm 0.37 a$ & $36.22 \pm 0.34 a$ & 0.007 \\
\hline & & $21: 00 \mathrm{~h}$ & $32.93 \pm 0.22 b$ & $33.84 \pm 0.22 b$ & \\
\hline & & $7: 00 \mathrm{~h}$ & $32.77 \pm 1.32$ & $31.96 \pm 1.3$ & \\
\hline & $\mathrm{RF}(\mathrm{bpm})$ & $15: 00 \mathrm{~h}$ & $86.95 \pm 3.85$ & $90.61 \pm 3.2$ & 0.377 \\
\hline & & $21: 00 \mathrm{~h}$ & $59.09 \pm 2.58$ & $55.43 \pm 2.6$ & \\
\hline
\end{tabular}

${ }^{*}$ Different letters within treatments and times for the same variable represent $P \leq 0.05$. 


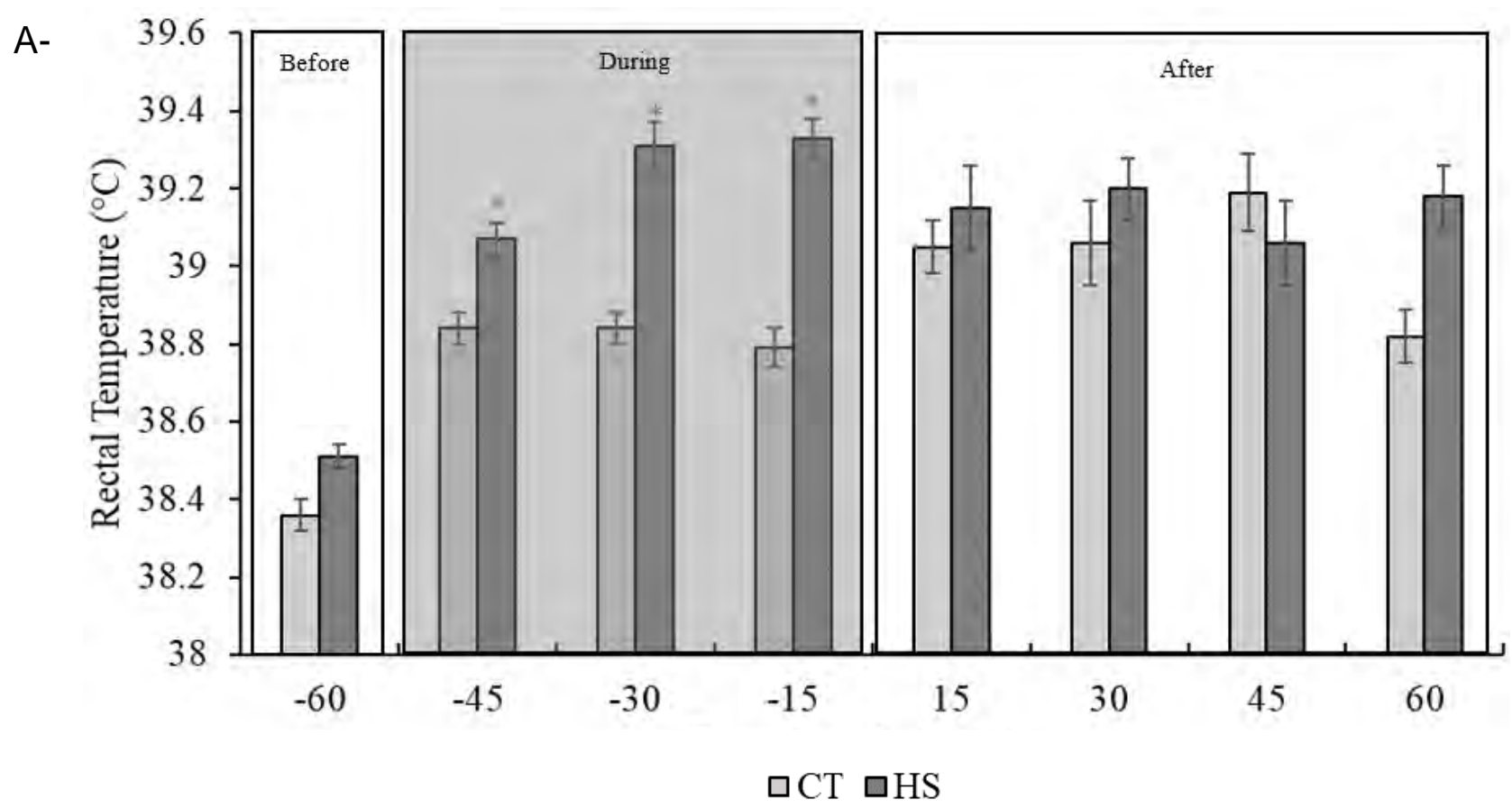


B-

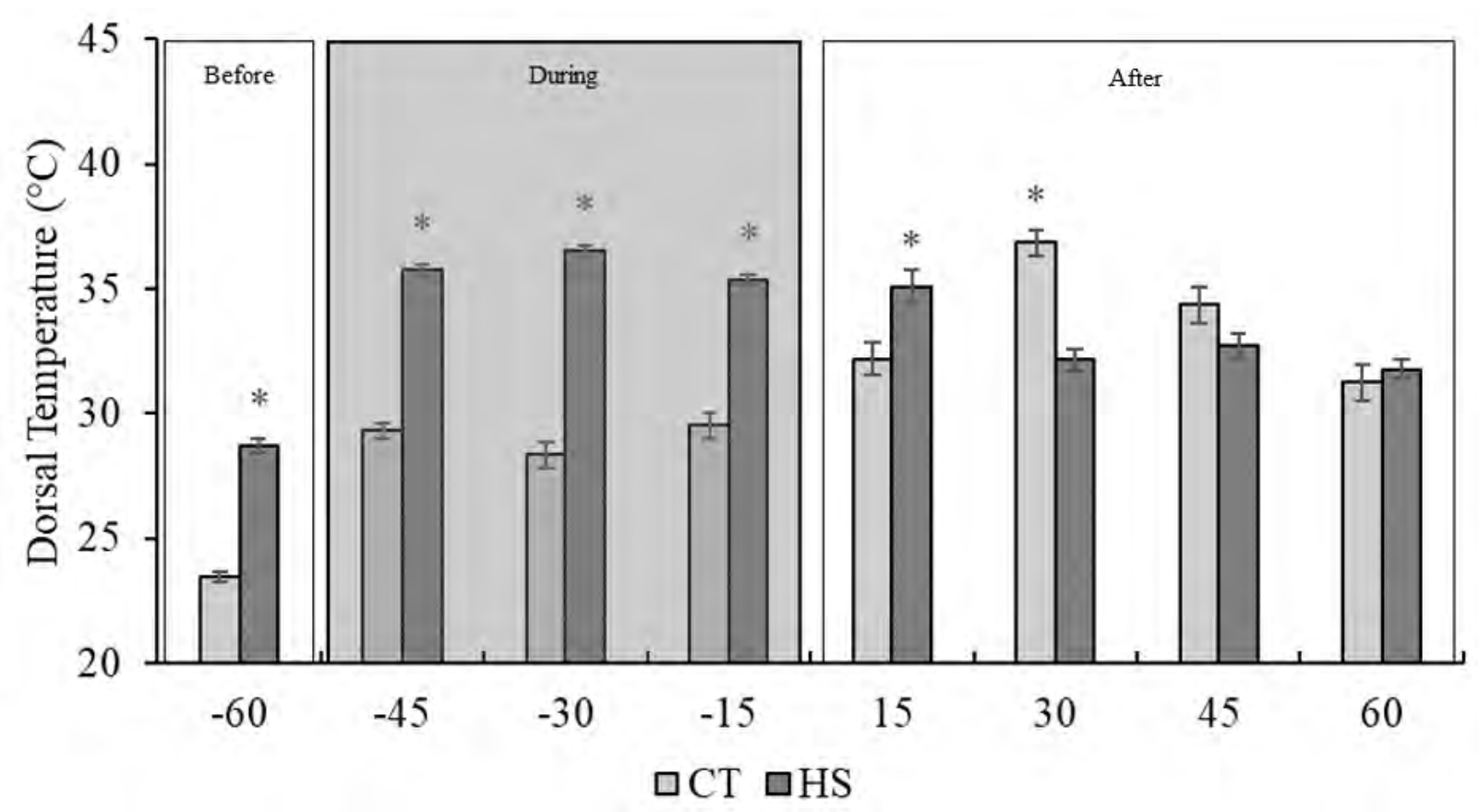

C.

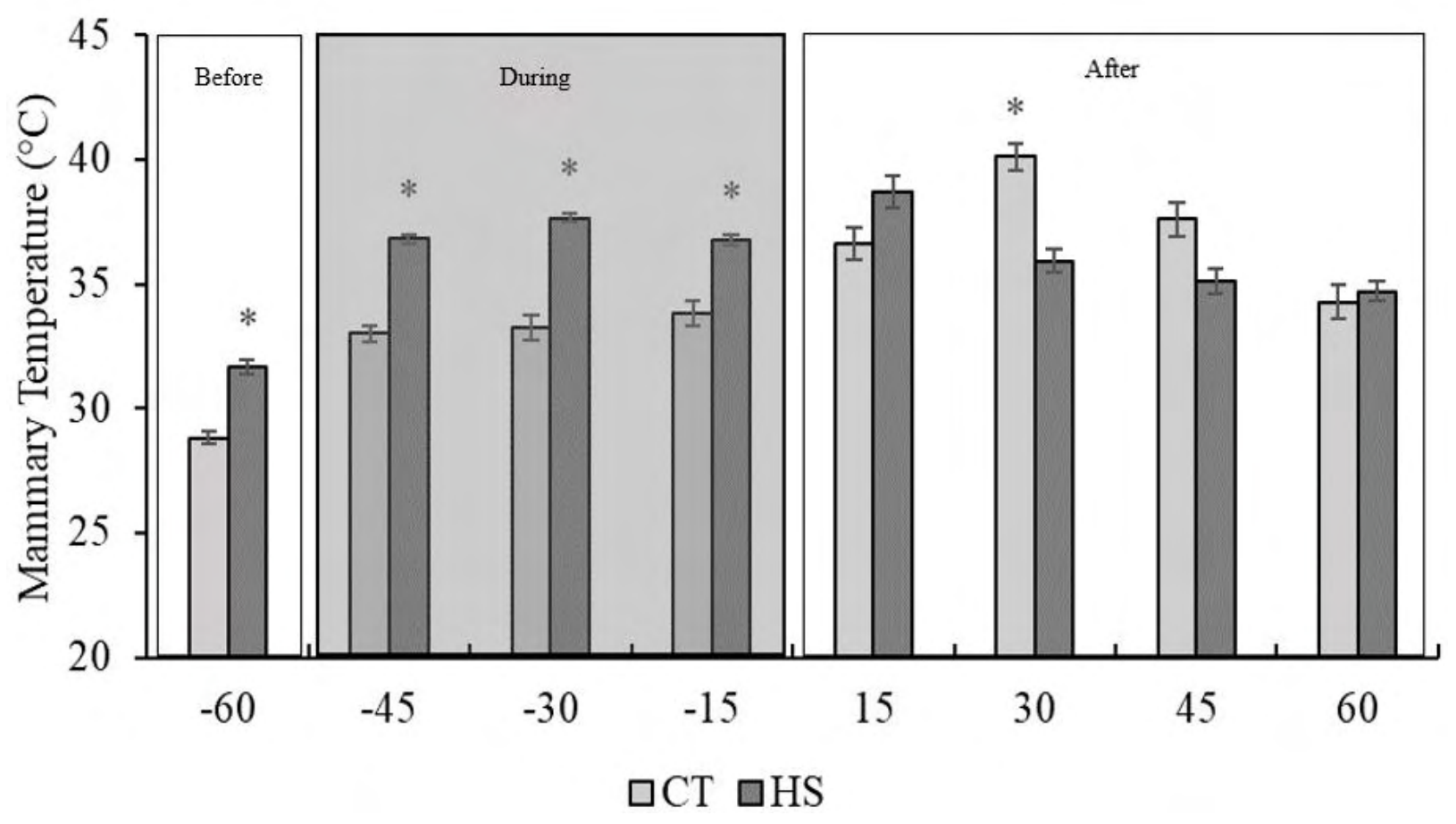


D-
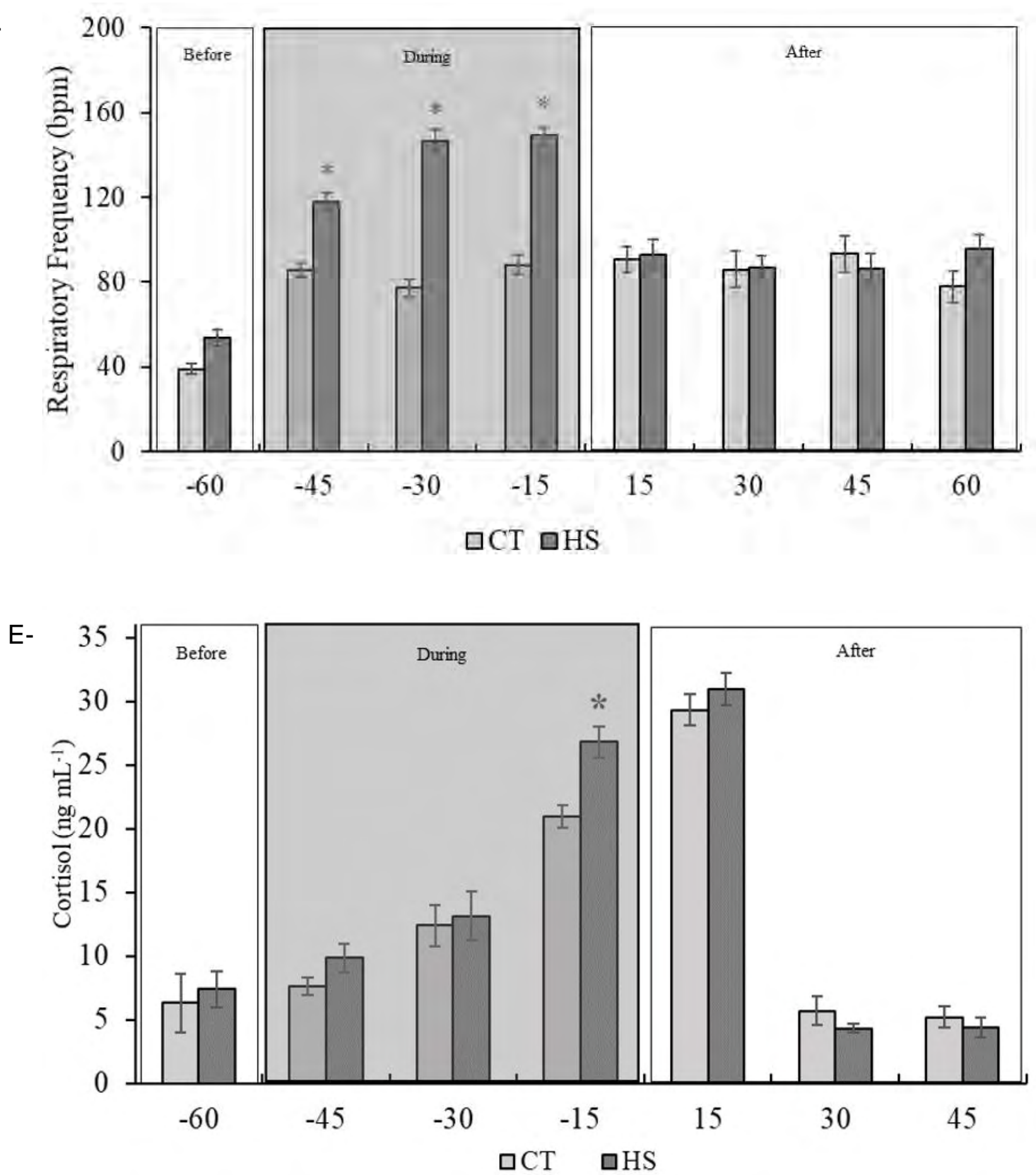

Figure 2. Rectal temperature (A), dorsal temperature (B) mammary temperature (C), respiratory frequency $(D)$, Cortisol $(E)$ before (on day -60 ), during (on days $-45,-30$, 15) and after heat challenge (on days $15,30,45$ and 60 ). ${ }^{*} P \leq 0.05$ within treatments for the same day related to partum. 
Table 5. Means follow by standard error of rectal temperature (RT), dorsal temperature (DT), mammary temperature (MT) and respiratory frequency (RF) considering the number of offspring (1,2 or 3$)$, during and after heat challenge for heat stress (HS) and control (CT) treatments.

\begin{tabular}{|c|c|c|c|c|c|}
\hline & \multicolumn{3}{|c|}{$\mathrm{N}^{\circ}$ Offspring } & \multirow[b]{2}{*}{ P-value } \\
\hline & & 1 & 2 & 3 & \\
\hline \multirow{4}{*}{ 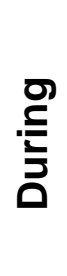 } & $\mathrm{RT}\left({ }^{\circ} \mathrm{C}\right)$ & $38.68 b \pm 0.02$ & $38.79 a \pm 0.02$ & $38.83 a \pm 0.03$ & $<.001$ \\
\hline & $\mathrm{DT}\left({ }^{\circ} \mathrm{C}\right)$ & $28.93 b \pm 0.21$ & $29.7 a \pm 0.18$ & $29.84 a \pm 0.34$ & 0.009 \\
\hline & $\mathrm{MT}\left({ }^{\circ} \mathrm{C}\right)$ & $33.05 b \pm 0.14$ & $33.44 a \pm 0.13$ & $33.65 a \pm 0.23$ & 0.048 \\
\hline & RF (bpm) & $81.89 \pm 1.89$ & $79.57 \pm 1.6$ & $86.72 \pm 3.41$ & 0.135 \\
\hline \multirow{4}{*}{$\underbrace{\frac{1}{4}}_{\frac{1}{4}}$} & $\mathrm{RT}\left({ }^{\circ} \mathrm{C}\right)$ & $38.66 \pm 0.04$ & $38.66 \pm 0.04$ & $38.54 \pm 0.07$ & 0.344 \\
\hline & $\mathrm{DT}\left({ }^{\circ} \mathrm{C}\right)$ & $27.28 \pm 0.37$ & $27.41 \pm 0.36$ & $27.85 \pm 0.68$ & 0.753 \\
\hline & $\mathrm{MT}\left({ }^{\circ} \mathrm{C}\right)$ & $33.3 \pm 0.25$ & $33.67 \pm 0.24$ & $33.12 \pm 0.46$ & 0.43 \\
\hline & $\mathrm{RF}$ (bpm) & $62.19 \pm 2.49$ & $58.65 \pm 2.06$ & $53.56 \pm 3.26$ & 0.151 \\
\hline
\end{tabular}

*Different letters within treatments and times for the same variable represent $P \leq 0.05$.

Heat Shock Response

No differences by treatment were observed on the expression of all HSPs preparturition (Figure 3). The gene expression of HSP60, HSP70 and HSP90 during heat challenge was respectively $0.04 \pm 0.02,4.93 \pm 1.01$ and $0.27 \pm 0.03$. After parturition, the gene expression was $0.10 \pm 0.02,2.35 \pm 0.52$ and $0.32 \pm 0.08$. The HSP70 was the most expressed during $(<.001)$ and after $(<.001)$ heat challenge. On day 15 post-parturition, the HSP70 was more expressed for HS than CT.

Pearson's correlations between environmental, physiological and HSPs are exposed in Table 6. Notably, strong correlations were observed within DT and THI $(r$ $=0.808)$ and for HSP70 and HSP60 ( $r=0.734)$. Other moderate and positive correlations were found within RT and THI $(r=0.448)$, MT and THI $(r=0.575)$, RF and DT $(r=0.557)$ and RF and MT $(r=0.46)$. 
A-

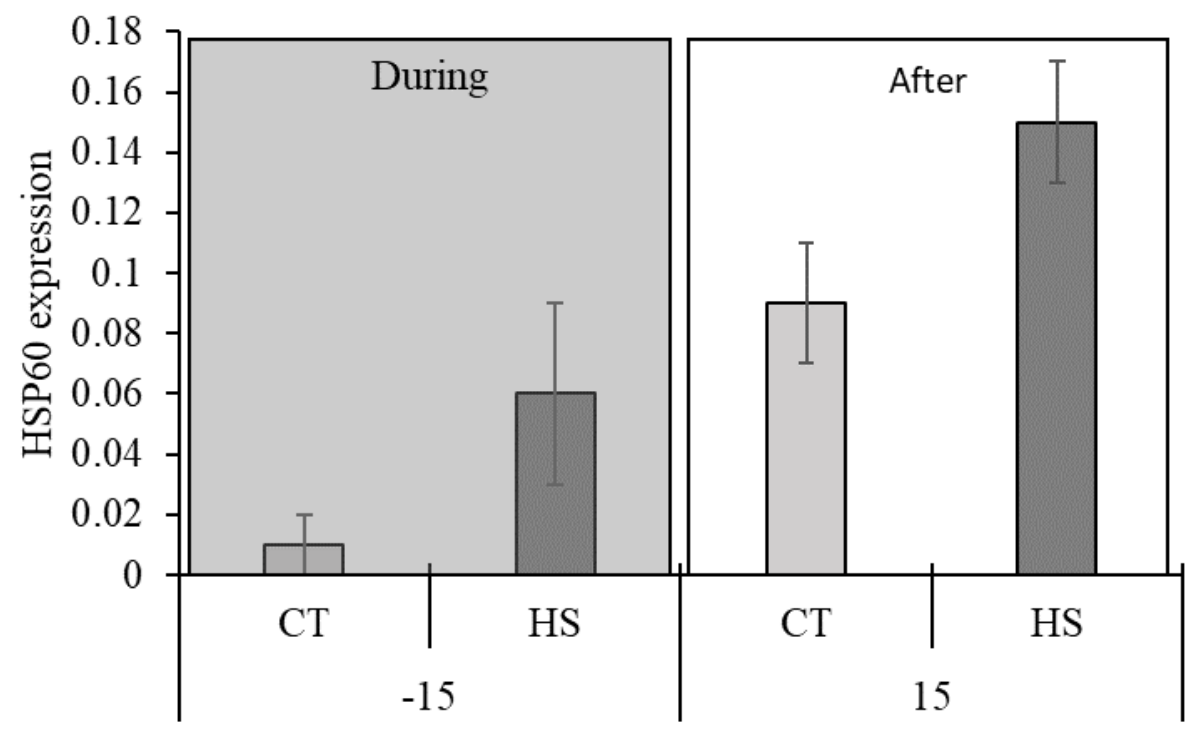

B-

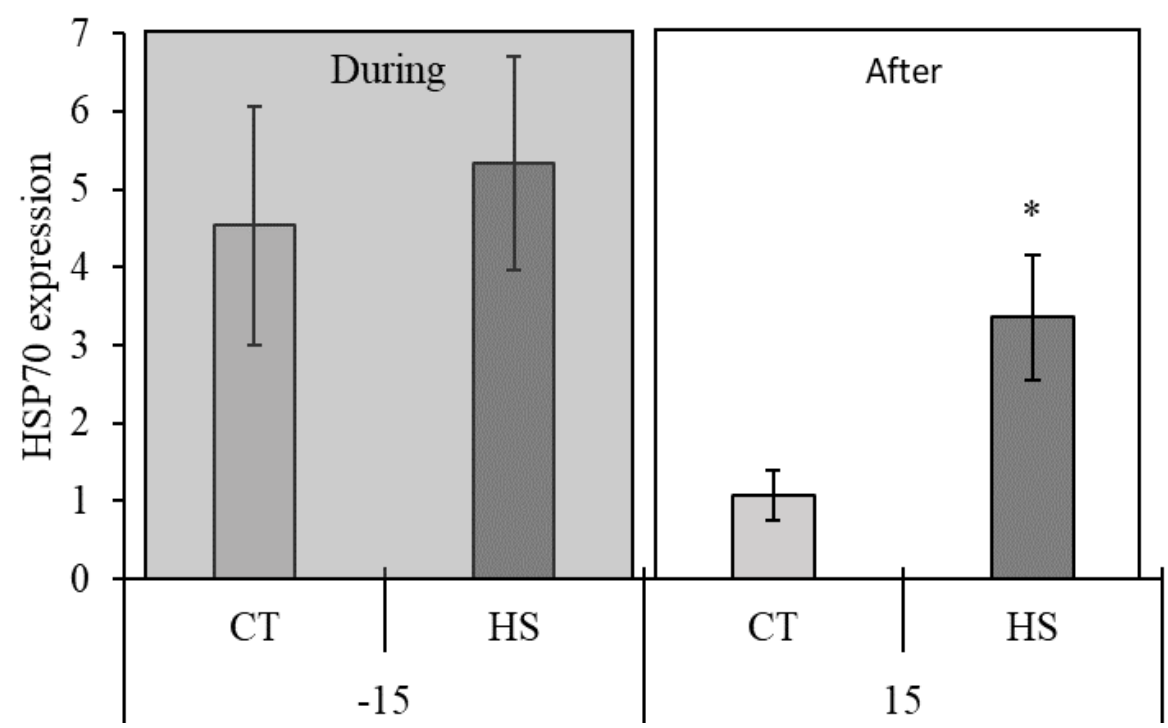

C-

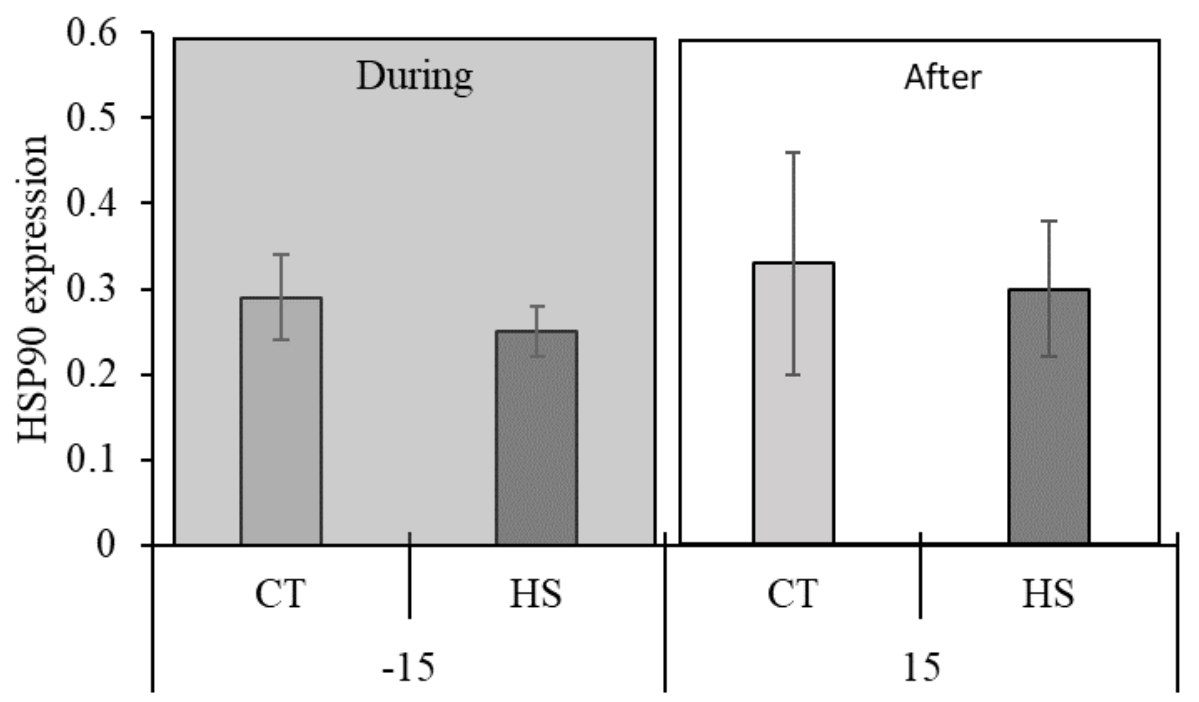

Figure 3. Gene expression of HSP60 (A), HSP70 (B) and HSP90 (C) for control (CT) heat stress (HS), during (-15 days' pre-partum) and after heat challenge (15 days' post-partum). ${ }^{*} \mathrm{P} \leq 0.05$ within treatments for the same day related to partum. 
Table 6. Pearson's correlation coefficients between environmental, physiological and heat shock protein variables measured at -15 and 15 related to partum ( $\mathrm{P}$-values under Pearson's correlation coefficients).

\begin{tabular}{|c|c|c|c|c|c|c|c|c|c|c|}
\hline & AT & $\mathbf{R H}$ & THI & RT & DT & MT & $\mathbf{R F}$ & Cort & HSP60 & HSP70 \\
\hline \multirow[t]{2}{*}{ RH (\%) } & 0.849 & & & & & & & & & \\
\hline & $<.001$ & & & & & & & & & \\
\hline \multirow[t]{2}{*}{ THI } & 0.908 & 0.782 & & & & & & & & \\
\hline & $<.001$ & $<.001$ & & & & & & & & \\
\hline \multirow[t]{2}{*}{$\mathrm{RT}\left({ }^{\circ} \mathrm{C}\right)$} & 0.315 & 0.234 & 0.448 & & & & & & & \\
\hline & 0.102 & 0.231 & 0.017 & & & & & & & \\
\hline \multirow[t]{2}{*}{ DT $\left({ }^{\circ} \mathrm{C}\right)$} & 0.79 & 0.85 & 0.808 & 0.265 & & & & & & \\
\hline & $<.001$ & $<.001$ & $<.001$ & 0.173 & & & & & & \\
\hline \multirow[t]{2}{*}{ MT $\left({ }^{\circ} \mathrm{C}\right)$} & 0.613 & 0.722 & 0.575 & 0.354 & 0.801 & & & & & \\
\hline & 0.001 & $<.001$ & 0.001 & 0.064 & $<.001$ & & & & & \\
\hline \multirow[t]{2}{*}{ RF (bpm) } & 0.364 & 0.444 & 0.308 & 0.244 & 0.557 & 0.46 & & & & \\
\hline & 0.057 & 0.018 & 0.111 & 0.21 & 0.002 & 0.014 & & & & \\
\hline \multirow[t]{2}{*}{ Cort (ng.dL-1) } & 0.022 & 0.049 & -0.255 & -0.286 & -0.068 & -0.046 & 0.117 & & & \\
\hline & 0.917 & 0.816 & 0.219 & 0.166 & 0.747 & 0.825 & 0.577 & & & \\
\hline \multirow[t]{2}{*}{ HSP60 } & -0.256 & -0.176 & -0.371 & -0.411 & -0.434 & -0.526 & -0.754 & 0.127 & & \\
\hline & 0.422 & 0.584 & 0.236 & 0.184 & 0.159 & 0.079 & 0.005 & 0.709 & & \\
\hline \multirow[t]{2}{*}{ HSP70 } & 0.149 & 0.237 & 0.194 & 0.21 & 0.356 & 0.274 & 0.041 & -0.378 & 0.734 & \\
\hline & 0.458 & 0.234 & 0.331 & 0.294 & 0.069 & 0.166 & 0.838 & 0.069 & 0.01 & \\
\hline \multirow[t]{2}{*}{ HSP90 } & 0.128 & -0.229 & -0.091 & 0.061 & -0.037 & -0.029 & 0.227 & 0.316 & -0.251 & -0.02 \\
\hline & 0.561 & 0.294 & 0.68 & 0.781 & 0.867 & 0.896 & 0.297 & 0.174 & 0.456 & 0.928 \\
\hline
\end{tabular}




\subsubsection{Discussion}

During heat stress, the AT was higher than the upper critical limit considered for goats $\left(20\right.$ to $\left.30^{\circ} \mathrm{C}\right)$ (SILVA, 2000; BAÊTA; SOUZA. 2010). The THI, in the present study, was between 85 and 90, classified as danger condition (SILANIKOVE and KOLUMAN, 2015). As expected during dry winter conditions in sub-tropical region, the $\mathrm{RH}$ varied from 32 to $68 \%$ and this percentage was lower than the recommended for goats (60\% to $80 \%)$, as established by Toussaint (1997). Although, little is known about the thermoneutral zone of Saanen goats, at final gestation and heat stressed, the animals could maintain normal rectal temperature when the air temperature was between $14^{\circ} \mathrm{C}$ to $24^{\circ} \mathrm{C}$.

Physiologically, the heat challenge imposed to HS treatment stimulated the increase of sensible (RT, DT and MT) and latent mechanisms (RF) to lose heat, different than CT. Even in heat stress, the mobilization of thermoregulatory mechanisms kept the RT on the physiological range $\left(38.5^{\circ} \mathrm{C}\right.$ to $\left.39.7^{\circ} \mathrm{C}\right)$ (SILVA, 2000; PEREIRA et al., 2011). At 7:00 and 21:00 h, the CT goats presented a respiratory frequency within 40 to $60 \mathrm{bpm}$. At 15:00 h, it was elevated for CT (84 bpm) and HS (136.53 bpm), keeping higher values for HS (93.25 bpm) at 21:00 h.

The HS goats were exposed to higher thermal load at the afternoon and evening because inside the climatic chamber the heat exchange was lower when compared to outside, similar to that found in other experiments with climatic chamber (BIANCA; KUNZ, 1978; SEJIAN; MAURYA; NAQVI, 2010; HAMZAOUI et al., 2013; ROMERO et al., 2013; DANGI et al., 2014, 2015). Nevertheless, for both CT and HS, the morning evaluations exhibited thermal neutral condition. As expected, throughout the day, the daily environmental variation impacted the physiological traits in both treatments, however, this variation was more pronounced in the climatic chamber. Consequently, the afternoon was the most stressful period and the evening the moment that the goats balance their heat load with the environment (DARCAN; GÜNEY, 2008; SALLES et al., 2009).

Our results are in accordance with observed by Aleena et al. (2018) which reported lower surface temperature during the morning than the afternoon during long-term heat exposition. Changes on skin temperature and respiratory rate were 
found for Aardi and Damascus goats and their crosses, when exposed to short-term (1 week) and long-term heat stress (8 weeks) (SAMARA et al.. 2016). According to the same authors, in this situation the most efficient way to dissipate heat is by latent mechanisms (sweating and painting).

In Anglo-Nubian goats, no change on rectal and skin temperature was observed when the air temperature was within 22 and $26^{\circ} \mathrm{C}$ (MAIA et al., 2016). However, when the air temperature was higher than $30^{\circ} \mathrm{C}$, goats maintained thermal equilibrium by latent mechanisms: evaporation and respiration (MAIA et al., 2016). In our findings, no change on rectal temperature was observed when the air temperature was between $14^{\circ} \mathrm{C}$ and $24^{\circ} \mathrm{C}$, however, the respiratory frequency was higher than $120 \mathrm{bpm}$ when the air temperature exceeds $30^{\circ} \mathrm{C}$.

Initially, we suggest that pregnancy status could influence the increment of core temperature during final gestation. For these reason, we studied if the number of fetus contributed to greater physiological changes. In fact, goats with 2 and 3 fetus had higher RT, DT and MT than the ones with only one. These physiological modifications are intrinsic from the pregnancy status (TODINI et al. 2007; CASTAGNINO et al.. 2015). For these reason, better attention should be given to proliferous species at final gestation, in order to avoid impairments caused by heat stress.

After heat challenge, no change was found for RT and RF, only higher DT and MT. On day 15, the DT remained higher for HS. The increase of superficial temperature is a thermoregulatory strategy that contributes for the heat exchange to the environment, but it is dependent of the air temperature (SOUZA et al., 2005; KOTRBA et al., 2007). On day 30, the HS goats presented lower superficial temperatures (DT and MT), it suggests that these animals were in better thermal balance than CT even in the same environmental conditions, as observed by Aleena et al. (2018).

On day -15 pre-parturition at 15:00 h, cortisol levels were higher for HS and remained elevated 15 post-parturition for both treatments. Before, during (days -30 and -15) and after heat challenge the cortisol release was basal as previous values. However, the cortisol release increased when parturition approaches, reaching the peak close to delivery. Our results agree with the report in sheep by Sireli et al. 
(2006), with increase of cortisol as gestation progress. At final gestation the accumulative effect of long-term heat stress was observed on day -15 pre-partum with maintenance. Otherwise, López et al. (2012) found on goats the increase of maternal cortisol level until the days 101-125 of gestation, although after 126 days they observed a reduction on it.

At cellular level, no change was observed for HSP60 and HSP90 gene expression, however higher gene expression of HSP70 for HS was observed on day 15 post-partum. Besides, the HSP70 was the most expressed during and after heat challenge. HSP70 is the most abundant on heat shock protein family, being highly conserved and inducible with crucial role during against deleterious effects promoted by environmental stress in goats (GUPTA et al., 2013; BANERJEE et al., 2014; MOHANARAO et al., 2014). In buffalos and cows the HSP70 was upregulated after 2 hours of heat stress and decreased the amount of transcripts until 12 hours of exposition (KISHORE et al., 2013). According to Dangi et al. (2014), the HSP70 is the most sensitive chaperone to air temperature fluctuations, with dramatically increase with body temperature elevation and quick reduction with body temperature decrease.

Our results shown that as soon as the parturition approaches (Figure 2E), not only the cortisol release increase but also the expression of HSPs for both CT and HS treatments. Moreover, on day 15 post-parturition, the HS goats kept higher levels of HSP70 gene expression, being an important biomarker of thermotolerance. Thermotolerance is one of the signals of adaptation when cells synthetize and accumulate heat shock proteins as a protective mechanism that allows the cells to survive to a subsequent stressor (MOSELEY, 1997). We suggest that the HSP70 is a reliable biological indicator that reflects the effect of long-term heat stress in goats, being an important tool for genetic selection of adapted animals (ALEENA et al,. 2018).

Although, no difference on the gene expression of HSP60 was observed during and after heat challenge by treatment, a strong and positive correlation was observed within HSP60 and HSP70. Normally, the HSP60 plays an important role during long-term acclimation with activated gene expression even in thermal neutrality. The HSP60 function are related to mitochondrial activity and survival 
(BARBOUR; TURNER, 2014). As expected the HSP90 did not vary its expression within treatments. Usually, it presents a stable expression overtime, participating in the complex HSP40/70/90 involved in the restoring protein conformation after heat stress (HANG; HE; FOX, 1995; MATHEW; MORIMOTO, 1998). 


\subsection{Conclusions}

The long-term heat stress at final gestation promoted the increase of respiratory frequency and cortisol levels in order to maintain thermal neutrality. At cellular level, the HSP70 was the most expressed during and after heat challenge. Our findings suggest that the respiratory frequency and the HSP70 are reliable biomarkers to evaluate thermal comfort and thermo-tolerance of Saanen goats on long-term heat stress. 


\section{References}

ADIN. G. et al. Effects of cooling dry cows under heat load conditions on mammary gland enzymatic activity. intake of food and water. and performance during the dry period and after parturition. Livestock Science. v. 124. n. 1-3. p. 189-195. 2009.

ALEENA. J. et al. Resilience of three indigenous goat breeds to heat stress based on phenotypic traits and PBMC HSP70 expression. International Journal of Biometeorology. p. 1-11. 2018.

AMORIM. F. T. et al. Insights into the role of heat shock protein 72 to whole-body heat acclimation in humans. Temperature (Austin. Tex.). v. 2. n. 4. p. 499-505. 2015.

BAÊTA, F.C.; SOUZA, C.F. Ambiência em edificações rurais: conforto animal. 2 ed. Viçosa: EDUFV, 269p., 2010.

BANERJEE. D. et al. seasonal variation in expression pattern of genes under HSP70. Cell Stress and Chaperones. v. 19. n. 3. p. 401-408. 2014.

BARBOUR. J. A.; TURNER. N. Mitochondrial stress signaling promotes cellular adaptations. International Journal of Cell Biology. v. 2014. p. 1-12. 2014.

BELL. A. W. et al. Chronic heat stress and prenatal development in sheep: I. conceptus growth and maternal plasma hormones and metabolites. Journal of Animal Science. v. 67. n. 12. p. 3289. 1 Dec. 1989.

BHARATI. J. et al. Expression dynamics of HSP70 during chronic heat stress in Tharparkar cattle. International Journal of Biometeorology. v. 61. n. 6. p. 10171027. 2017.

BIANCA. W.; KUNZ. P. Physiological reactions of three breeds of goats to cold. heat and high altitude. Livestock Production Science. v. 5. n. 1. p. 57-69. 1978.

BOYAZOGLU. J.; HATZIMINAOGLOU. I.; MORAND-FEHR. P. The role of the goat in society: past. present and perspectives for the future. Small Ruminant Research. v. 60. n. 1. p. 13-23. 2005. 
BROWN. D. E. et al. Heat stress effects on fetal development during late gestation in the ewe. Journal of Animal Science. v. 44. n. 3. 1977.

BUFFINGTON. D. E.; COLLIER. R. J.; CANTON. G. H. Shade management systems to reduce heat stress for dairy cows in hot. humid climates. Transactions of the ASAE. v. 26. n. 6. p. 1798-1802. 1982.

CAPUCO. A. V.; AKERS. R. M.; SMITH. J. J. Mammary growth in holstein cows during the dry period: quantification of nucleic acids and histology. Journal of Dairy Science. v. 80. n. 3. p. 477-487. 1997.

CASTAGNINO. D. de S. et al. Changes in maternal body composition and metabolism of dairy goats during pregnancy. Revista Brasileira de Zootecnia. v. 44. n. 3. p. 92-102. 2015.

DANGI. S. S. et al. Expression of HSPs: an adaptive mechanism during long-term heat stress in goats (capra hircus). International Journal of Biometeorology. v. 59. n. 8. p. 1095-1106. 2015.

DANGI. S. S. et al. Impact of short-term heat stress on physiological responses and expression profile of HSPs in Barbari Goats. International Journal of

Biometeorology. v. 58. n. 10. p. 2085-93. 2014.

DARCAN. N.; GÜNEY. O. Alleviation of climatic stress of dairy goats in Mediterranean climate. Small Ruminant Research. v. 74. n. 1. p. 212-215. 2008.

DURAIRAJANAYAGAM. D.; AGARWAL. A.; ONG. C. Causes, effects and molecular mechanisms of testicular heat stress. Reproductive BioMedicine Online. v. 30. n. 1. p. 14-27. 2015.

GEBREGEZIABHEAR. E. The effect of stress on productivity of animals: a review, Journal of Biology, Agriculture and Healthcare. v. 5, n. 3, p. 1-9, 2015.

GUPTA. M. et al. Physiological, biochemical and molecular responses to thermal stress in goats. International Journal of Livestock Research. v. 3. n. 2. p. 27. 2013. 
HAMZAOUI. S. et al. Physiological responses and lactational performances of latelactation dairy goats under heat stress conditions. Journal of Dairy Science. v. 96. n. 10. p. 6355-6365. 2013.

HANG. H.; HE. L.; FOX. M. H. Cell cycle variation of HSP70 levels in Hela cells at $37^{\circ} \mathrm{C}$ and after a heat shock. Journal of Cellular Physiology. v. 165. n. 2. p. 367375. Nov. 1995.

HOODA. O. K.; UPADHYAY. R. C. Physiological responses. growth rate and blood metabolites under feed restriction and thermal exposure in kids. Journal of Stress Physiology and Biochemistry. v. 10. n. 2. p. 214-227. 2014.

HOOPER. H. B.; et al. Heat loss efficiency and HSPS gene expression of Nellore cows in tropical climate conditions. International Journal of Biometeorology. p. 112. 2018.

IPCC. Climate Change 2013: The Physical Science Basis. Contribution of working group I: the fifth assessment report of the intergovernmental panel on climate change. Cambridge University Press. 2013.

KISHORE. A. et al. Peripheral blood mononuclear cells: a potential cellular system to understand differential heat shock response across native cattle (bos indicus). exotic cattle (bos taurus). and riverine buffaloes (bubalus bubalis) of india. Cell Stress \& Chaperones. v. 19. n. 5. p. 613-621. 2013.

KOTRBA. R. et al. Comparison between the coat temperature of the eland and dairy cattle by infrared thermography. Journal of Thermal Biology. v. 32. n. 6. p. 355359. 2007.

LÓPEZ. G. et al. Blood levels of cortisol and glucocorticoid receptors in liver and placenta of goats at different stages of gestation. Veterinaria México. v. 43. n. 3. p. 213-223. 2012.

MACARIO. A. J. L.; MACARIO. E. C. De. Molecular chaperones: multiple functions. pathologies. and potencial applications. Frontiers in Bioscience. v. 12. p. 25882600. 2007.

MAIA. A. S. C. et al. Thermoregulatory responses of goats in hot environments. International Journal of Biometeorology. v. 59. n. 8. p. 1025-1033. 2015. 
MAIA. A. S. C. et al. Thermal Equilibrium of Goats. Journal of Thermal Biology. v. 58. p. 43-49. 2016.

MATHEW. A.; MORIMOTO. R. I. Role of the heat-shock response in the life and death of proteins. Annals of the New York Academy of Sciences. v. 851. p. 99111. 1998.

MOHANARAO. G. J. et al. HSP70 family genes and HSP27 expression in response to heat and cold stress in vitro in peripheral blood mononuclear cells of goat (capra hircus). Small Ruminant Research. v. 116. n. 2-3. p. 94-99. 2014.

MOSELEY. P. L. Invited Review: heat shock proteins and heat adaptation of the whole organism. Journal of Applied Physiology. v. 83. n. 5. p. 1413-1417. 1997.

NARAYAN. E.; SAWYER. G.; PARISELLA. S. Faecal glucocorticoid metabolites and body temperature in australian merino ewes (ovis aries) during summer artificial insemination (Al) program. Plos One. v. 13. n. 1. p. e0191961. 2018.

PEREIRA. G. M. et al. Avaliação do comportamento fisiológico de caprinos da raça saanen no semiárido paraibano. Revista Verde de Agroecologia e Desenvolvimento Sustentável. v. 6. n. 1. p. 83-88. 2011.

RIBEIRO. N. L. et al. Adaptive profile of Garfagnina goat breed assessed through physiological, haematological, biochemical and hormonal parameters. Small Ruminant Research. v. 144. p. 236-241. 2016.

ROJAS-DOWNING. M. M. et al. Climate change and livestock: impacts. adaptation. and mitigation. Climate Risk Management. v. 16. p. 145-163. 2017.

ROMERO. R. D. et al. Differences in body temperature. cell viability and HSP-70 concentrations between Pelibuey and Suffolk sheep under heat stress. Tropical Animal Health and Production. v. 45. n. 8. p. 1691-1996. 2013.

SALAMA. A. A. K. et al. R. different levels of response to heat stress in dairy goats. Small Ruminant Research. v. 121. n. 1. p. 73-79. 2014.

SALLES. M. G. F. et al. Physiological heat stress responses of Saanen goats in tropical climate. Ciência Animal. v. 1. p. 19-28. 2009. 
SAMARA. E. M. et al. Assessment of heat tolerance and production performance of Aardi, Damascus, and their crossbred goats. International Journal of

Biometeorology. v. 60. n. 9. p. 1377-1387. 2016.

SEJIAN. V.; MAURYA. V. P.; NAQVI. S. M. K. Adaptive capability as indicated by endocrine and biochemical responses of Malpura ewes subjected to combined stresses (thermal and nutritional) in a semi-arid tropical environment. International Journal of Biometeorology. v. 54. n. 6. p. 653-661. 2010.

SILANIKOVE. N.; KOLUMAN. D. N. Impact of climate change on the dairy industry in temperate zones: predications on the overall negative impact and on the positive role of dairy goats in adaptation to earth warming. Small Ruminant Research. v. 123. n. 1. p. 27-34. 2015.

SILVA. R. G. Introdução à bioclimatologia animal. São Paulo: Ed. Nobel. 2000.

SIRELI. M. et al. Pregnancy toxemia in twin pregnant Sakiz Sheep. Indian Veterinary Journal. v. 83. p. 752-754. 2006.

SOUZA. E. D. de et al. Determinação dos parâmetros fisiológicos e gradiente térmico de diferentes grupos genéticos de caprinos no semi-árido. Ciência e Agrotecnologia. v. 29. n. 1. p. 177-184. 2005.

TAO. S. et al. Effect of heat stress during the dry period on mammary gland development. Journal of Dairy Science. v. 94. n. 12. p. 5976-86. 2011.

THORNTON. P. K. et al. The impacts of climate change on livestock and livestock systems in developing countries: a review of what we know and what we need to know. Agricultural Systems. v. 101. n. 3. p. 113-127. 2009.

TODINI. L. et al. Plasma total $\mathrm{t} 3$ and $\mathrm{t} 4$ concentrations in goats at different physiological stages. as affected by the energy intake. Small Ruminant Research. v. 68. n. 3. p. 285-290. 2007.

TOUSSAINT. G. The housing of milk goats livestock. Production Science. V. 49, p. 151-164, 1997. 


\title{
4. HEAT STRESS AT FINAL GESTATION OF SAANEN GOATS: LACTATION PERFORMANCE AND MAMMARY CELLULAR RESPONSES
}

\begin{abstract}
Little is known about the effects of heat stress at final gestation on the subsequent lactation of dairy goats. For this reason, the milk production, composition and gene expression of mammary epithelial cells were evaluated. Saanen goats were randomly assigned in two treatments: control (CT) and heat stress (HS) at final gestation period. The HS was performed in climatic chamber per six hours for 45 days before parturition in which the maximum air temperature reached was $37^{\circ} \mathrm{C}$. After parturition, the HS goats were housed in the same conditions as the CT group. At final gestation, there was a significant increase in apoptosis transcripts of the p53 and Bax for HS when compared to CT. Indeed, HS goats showed a significant increase on expression of HSP27 gene during gestation and lactation, and higher SCC in milk than CT goats. Furthermore, during lactation, HS goats presented lower milk production than CT goats. Lower gene expression for the prolactin receptor (PRLr) for HS goats after parturition explained the reduction in milk production on subsequent lactation when compared to CT goats. In conclusion, HS impairs milk production and composition by altering the expression of p53, Bax, HSP27 and PRLr genes in epithelial cells of Saanen goats during and after long-term heat stress.
\end{abstract}

Keywords: Bax, epithelial cells, HSP27, milk yield, PRLr. 


\section{Resumo (Portuguese)}

Pouco se sabe sobre os efeitos do estresse térmico durante a fase final de gestação na lactação subsequente de cabras leiteiras. Por este motivo, a produção, composição do leite e expressão gênica de células epiteliais mamárias foram avaliadas neste estudo. Cabras da raça Saanen foram distribuídas aleatoriamente em dois tratamentos, controle (CT) e estresse térmico (ET) no período final da gestação. O HS foi realizado em câmara climática por seis horas durante 45 dias antes do parto, em que a temperatura máxima foi de $37^{\circ} \mathrm{C}$. Após o parto, as cabras HS foram alojadas nas mesmas condições do grupo CT. No final da gestação, houve aumento dos transcritos de apoptose, p53 e Bax, para HS. De fato, as cabras HS mostraram um aumento significativo na expressão do gene HSP27 durante a gestação e lactação, e maior CCS no leite que as cabras CT. Além disso, durante a lactação, as cabras HS apresentaram menor produção de leite que as cabras do CT. Houve menor expressão gênica do receptor de prolactina (PRLr) para HS após o parto o que explicou a redução na produção de leite na lactação subsequente quando comparada com as cabras CT. Em conclusão, o estresse térmico prejudica a produção e composição do leite, alterando a expressão dos genes p53, Bax, HSP27 e PRLr das células epiteliais mamárias de cabras Saanen durante e após o estresse por calor a longo prazo.

Palavras-chave: Bax, células epiteliais, HSP27, produção de leite, PRLr. 


\subsection{Introduction}

The effects of climate change on livestock are becoming more highlighted year by year, exposing them to conditions over their thermal neutral zone (IPCC, 2013; BELHADJ SLIMEN et al., 2016). In cows, the effect of heat stress is more pronounced during final gestation when there is an expressive change in mammary gland, associated to cell apoptosis, involution of mammary gland and dry period (CAPUCO et al., 1997; NØRGAARD et al., 2008; ADIN et al., 2009). In goats as in other ruminants, there is an expressive development of mammary gland related to endocrine changes measured on last weeks before the parturition, which increase of proliferation rate and mammary cells number, mainly epithelial cells (ROWSON et al., 2012).

Although, the reduction of animal productivity caused by heat stress is more frequently reported in cattle (KADZERE et al., 2002; WEST, 2003; MADER and DAVIS, 2006; TAO et al., 2012; COLLIER et al., 2017), dairy goats exposed to moderate to severe heat stress decreased their milk yield from $3 \%$ to $13 \%$, and presented lower milk fat, protein, lactose and total solids (SANO et al., 1985; BRASIL et al., 2000). These losses under heat stress are associated to several biological responses necessary to the maintenance of thermal equilibrium and homeostasis (MOBERG, G. and MENCH, J. 2000; KADZERE et al., 2002; COLLIER et al., 2017). However, the effects of chronic heat stress before the parturition of goats on mammary gland and subsequent milk yield were not elucidated.

Taking in accounting that milk yield is related to epithelial cells number and their synthesis capacity (CAPUCO et al., 1997; NØRGAARD et al., 2008) some authors have showed that heat stress negatively impacts milk yield by changing mammary gland development (TAO et al., 2011; TAO and DAHL, 2013). In this context, no significant difference in apoptosis rate was found in mammary epithelial cells in cows submitted to heat stress (TAO et al., 2011). However, proliferation impairments and reduction of milk yield have been reported in cows without cooling during the dry period (TAO and DAHL, 2013). This negative impact of heat stress has been related to prolactin actions, based in studies concerning the photoperiod effect (AUCHTUNG et al., 2005) or heat stress effect in lactating goats (SANO et al., 1985). 
In contrast, it also increases the synthesis of different heat shock proteins (HSPs) that protect different cells (NEUER et al., 2000; MOHANARAO et al., 2014; DANGI et al., 2016) and several HSPs are related to cellular survival during climate challenges (BAHR et al., 2014; OZAYDIN et al., 2016; SHOCHET et al., 2016).

Hence, there are evidences that heat stress could impacts mammary epithelial cells, however the knowledge about the mechanisms related to it negative effects are still limited. For this reason, the aim of the present study was to evaluate the effect of heat stress imposed at final gestation on gene expression related to apoptosis ( $p 53$, Bax and Bcl-2) or survival (HSP27, HSP70 and PRLr) of the mammary epithelial cells, and their impact in milk quality and milk yield in subsequent lactations of Saanen goats.

\subsubsection{Material and methods}

Experimental site and Ethical Approval

All the animal procedures of this study were approved by the Animal Ethic Committee (CEUA, protocol 3709280316) of the Faculty of Animal Science and Food Engineering (FZEA) of the University of Sao Paulo (USP), which adheres to Brazilian federal law. The experiment was conducted from May to September at the Laboratory of Animal Physiology in Pirassununga, Brazil (21 58 'S and $\left.47^{\circ} 26^{\prime \prime} \mathrm{W}\right)$. The climate is categorized as subtropical humid (Köeppen-Geiger classification) with annual rainfall of $1238 \mathrm{~mm}$ per year. Air temperature and relative humidity were constantly measured each 30 minutes using the LogBox-RHT-LCD data-loggers (NOVUS, Miami, FL). Temperature and humidity index (THI) was calculated using the following equation: $\mathrm{THI}=\left[0.8 \times\right.$ air temperature $\left.\left({ }^{\circ} \mathrm{C}\right)\right]+[(\%$ relative humidity $/ 100) \times$ (air temperature - 14.4)] + 46.4 (BUFFINGTON et al., 1981). 
Animals, Experimental Design and Housing

Healthy, multiparous and pregnant Saanen goats were used to conduct this experiment. The experimental goats were randomly assigned in two treatments, control (CT; $n=16)$ and heat stress (HS; $n=16)$. The average and SEM of body weight previous to the experiment for CT and HS was $65.71 \pm 2.16 \mathrm{~kg}$ and $61.94 \pm$ $2.76 \mathrm{~kg}(\mathrm{P}=0.29)$, the body condition score was $3.26 \pm 0.17$ and $3.10 \pm 0.20(P=$ $0.55)$, the number of lactations was $1.28 \pm 1.18$ and $1.13 \pm 0.09$, and the previous milk production was $2.0 \pm 0.25 \mathrm{~kg}$ and $1.9 \pm 0.22(P=0.83)$.

The experiment was conducted from 60 days' pre-parturition to 60 days' postparturition. The first 15 days was considered adaptation period for both groups, for habituation to the new environment and social hierarchy familiarization. The CT goats were housed in thermal neutral conditions, in a shaded and well ventilated pen. The HS goats were housed in a climatic chamber where was performed the heat challenge, from 1000 to $1600 \mathrm{~h}$, set up to reach the maximum air temperature (AT) of $37^{\circ} \mathrm{C}$. The lights on both places was kept on from 07:00 $\mathrm{h}$ to $18: 00 \mathrm{~h}$, provided by fluorescent light to approximately 100-lux intensity at eye level of the goats. The relative humidity $(\mathrm{RH})$ was not manipulated. After parturition, the HS goats were housed in the same conditions as the CT group, in thermal neutral condition. The analysis of the thermal condition of the present study in order to characterize the heat stress was based on the previous study conducted with Saanen goats (HOOPER et al., 2018).

Goats had free access to feeding, mineral salt and water troughs. The feed was compound by $60 \%$ of concentrate and $40 \%$ of roughage, providing $100 \%$ the requirements of animals (NCR, 2007). The diet contained corn grain, soybean bran, soybean oil, limestone and mineral premix. It was offered twice a day with $15 \%$ of leftovers, adjusted taking in account the body weight, category (gestation, lactation), productive cycle (lactation phase) and production. The ingredient composition of the diet for both treatments is presented on Table 1. 
Table 1. Ingredient composition of the diet for both treatments offered during the experimental period.

\begin{tabular}{|c|c|c|c|c|c|c|}
\hline Ingredient & $\begin{array}{l}\text { DM } \\
(\%)\end{array}$ & $\begin{array}{l}\text { CP } \\
(\%)\end{array}$ & $\begin{array}{c}E E \\
(\% \text { of } D M)\end{array}$ & $\begin{array}{c}\text { MM } \\
(\% \text { DM) }\end{array}$ & $\begin{array}{c}\text { NDF } \\
(\% \text { DM) }\end{array}$ & $\begin{array}{c}\mathrm{CE} \\
(\% \mathrm{MS})\end{array}$ \\
\hline \multirow{4}{*}{$\begin{array}{c}\text { Corn Silage }(\mathrm{kg}) \\
\text { Corn meal }(\mathrm{kg}) \\
\text { Soy bean meal } \\
(\mathrm{kg}) \\
\text { Hay }(\mathrm{kg})\end{array}$} & 44.51 & 15.05 & 6.17 & 7.64 & 53.31 & 7.64 \\
\hline & 88.52 & 9.76 & 5.38 & 1.53 & 67.22 & 1.53 \\
\hline & 89.39 & 51.97 & 1.74 & 7.5 & 20.52 & 7.8 \\
\hline & 99.46 & 6.42 & - & - & - & - \\
\hline Mineral Mix $(\mathbf{k g})^{\star}$ & 99.9 & - & - & - & - & - \\
\hline \multicolumn{7}{|c|}{$\begin{array}{l}\mathrm{DM} \text { - dry matter; CP - crude protein; EE - ether extract; } \mathrm{MM} \mathrm{-} \mathrm{mineral} \mathrm{matter;} \mathrm{NDF} \mathrm{-} \\
\text { neutral detergent fiber; CE - crude energy }\end{array}$} \\
\hline \multicolumn{7}{|c|}{$\begin{array}{l}{ }^{*} \text { Mineral Mix included: } \mathrm{Ca}(\max )=146 \mathrm{~g} ; \mathrm{Ca}(\min )=48 \mathrm{~g} ; \mathrm{Cu}(\min )=500 \mathrm{mg} ; \mathrm{Cr} \\
(\mathrm{min})=10 \mathrm{mg} ; \mathrm{S}(\mathrm{min})=15 \mathrm{~g} ; \mathrm{Fe}(\min ) 2.000 \mathrm{mg} ; \mathrm{F}(\max )=850 \mathrm{mg} ; \mathrm{P}(\min )=85 \\
\mathrm{mg} ; \mathrm{I}(\min )=75 \mathrm{mg} ; \mathrm{Mg}(\min )=15 \mathrm{mg} ; \mathrm{Mn}(\min )=1.400 \mathrm{mg} ; \mathrm{Se}(\min )=140 \mathrm{~g} ; \mathrm{Zn} \\
(\min )=4.400 \mathrm{mg} ;\end{array}$} \\
\hline
\end{tabular}

\section{Lactation performance}

The body weight (BW) and body condition score (BCS) were monitored during the experiment period before (day -60), during (days $-45,-30,-15$ ) and after heat challenge (days 15, 30, 45, 60). The BCS was examined by palpating the ribs and side of spine, being classified as very thin (1), thin (2), normal (3), fat (4) and very fat (5).

The goat kids were separated from their mothers after birth and had received colostrum and milk by artificial feeding. Saanen goats were milked twice day in a mechanical milking machine (Westfalia Surge), regulated to maintain a vacuum level of $48 \mathrm{kPa}$ and a pulse rate of $120 \mathrm{cycles} / \mathrm{min}$. Before milking, the goat teats were tested for clinic mastitis, pre-dipped and dried. The machine had been attached to the teat until the end of milking. In sequence, the teats were post-dipped, the daily milk yield recorded and the animal was released from the milk parlor. To study the effect of heat stress, the lactation was divided in weeks 1, 2 and 3 (early), weeks 4 to 12 (plateau), weeks 13 to 24 (middle) and weeks 25 to 35 (late) to better comprehend the effect of treatment on milk yield, composition and quality. Energycorrected milk (ECM) was calculated following the equation proposed by Flores et al. (2009): $E C M=[0.327 \times \cdot$ milk yield $(\mathrm{kg} / \mathrm{d})]+[12.86 \cdot \times$ fat yield $(\mathrm{kg} / \mathrm{d})]+[7.65 \times \cdot$ protein yield $(\mathrm{kg} / \mathrm{d})]$. 
Once a week, milk samples were aseptically collected from both teats in a sterilize tube, for microbiological analysis, milk content and somatic cell count (SCC). The milk content was performed using the equipment MilkScope Expert (RAZGRAD, Bulgary) to obtain fat, lactose, total dry extract, protein, water, freezing point and minerals. The Dornic method was used to verify the acidity. The SCC analysis was determined with $10 \mu \mathrm{l}$ of milk using pyronin Y-methil green by direct microscopy. The SCC was performed counting the leukocytes in the slice, the number found was multiplied with the microscope factor and the final result converted in log.

Microbiological analysis was performed in three different culture media with $0.1 \mathrm{~mL}$ of pure milk. The total colony counts were obtained by spreading samples onto Plate Count Agar (PCA), Baird-Parker agar (BP) and supplemented with egg yolk tellurite emulsion (LABORCLIN, Paraná, Brazil) to identify $S$. aureus, and MacConkey Agar (MAC) for gram-negative enteric bacilli was used (ACUMEDIA, Michigan, USA). Plates were incubated at $37^{\circ} \mathrm{C}$ for $48 \mathrm{~h}$, and after the colonies were counted as units per milliliter.

Mammary cellular responses

Mammary gland biopsies were performed in 14 goats: 7 CT and $7 \mathrm{HS}$, at 07:00h on days $-30,-15,15$ and 30 related to parturition. After trichotomy, the central region of each mammary gland was locally blocked by anesthetic procedure, a small incision was made in the skin with and the disposable biopsy needle was inserted to collect the mammary tissue with approximately $2.0 \times 0.5 \mathrm{~cm}$. The tissues obtained were transferred to a sterile tube containing PBS. At laboratory, the samples obtained were stored in $-80^{\circ} \mathrm{C}$ until analysis. After all procedures, the incision was topically treated, the milk discharged and the animal health monitored.

Total RNA was extracted and purified using Purelink RNA Mini Kit (INVITROGEN, Carlsbad, CA, USA). The concentrations were determined by Qubit 2.0 Fluorometric Quantification (THERMO FISHER SCIENTIFIC, Wilmington, DE. USA). The material obtained was treated with RNase-Free DNase (PROMEGA, Madison, WI, USA) to exclude genomic DNA contaminations. The RNA was reverse transcribed into cDNA using GoScript TM Reverse Transcriptase kit (PROMEGA, 
Madison, WI, USA). Relative gene expression of heat shock proteins 27 (HSP27) and 70 (HSP70), bcl-2-like protein X (Bax), B-cell lymphoma 2 (Bcl-2), protein 53 (p53) and prolactin receptor long isoform (PRLr) was assessed by real-time quantitative reverse transcription (RT-PCR) using the StepOne ${ }^{\mathrm{TM}}$ Real-Time PCR System (INVITROGEN, Carlsbad, CA) (Table 2). SYBRß Green (Invitrogen, Carlsbad, CA, USA) was used as fluorescent label and each reaction had a total volume of $20 \mu \mathrm{L}$, using 96 well plates (INVITROGEN, Carlsbad, CA, USA) and transparent adhesive tapes to seal them.

\begin{tabular}{|c|c|c|c|c|}
\hline Genes & Primer sequences & Amplicon & Gene reference & Eff $(\%)$ \\
\hline GAPDH & $\begin{array}{l}\text { 3'GGGTCATCATCTCTGCACCT5' } \\
\text { 5'GGTCATAAGTCCCTCCACGA3' }\end{array}$ & 181 & NM_001034034.2 & 101.5 \\
\hline HSP27 & $\begin{array}{l}\text { 3'ACTGGCTCCTCATCTCACTC5' } \\
\text { 5'TGTTCAATAATCACTGTCCTTCC3' }\end{array}$ & 147 & NM_001166609.1 & 109.9 \\
\hline HSP70 & $\begin{array}{l}\text { 3'GACGACGGCATCTTCAAG5' } \\
\text { 5'GTTCTGGCTGATGTCCTTC3' }\end{array}$ & 171 & U09861 & 115.3 \\
\hline p53 & $\begin{array}{l}\text { 3'CAAGAAGTTGGAGCACAT5' } \\
\text { 5'CGGTCGTCCAAATACTCC3' }\end{array}$ & 141 & NM_174201 & 104.9 \\
\hline Bax & $\begin{array}{l}\text { 3'TCGGTCTCAACGGCTACA5' } \\
\text { 5'CCACTCCAGCCACAAAGA3' }\end{array}$ & 189 & NM_173894 & 97.8 \\
\hline Bcl-2 & $\begin{array}{l}\text { 3'GATGACCGAGTATCTGAACCG5' } \\
\text { 5'GACAGCCAGGAGAAATCAAACA3' }\end{array}$ & 120 & NM_001166486 & 98.4 \\
\hline PRLr & $\begin{array}{c}\text { 3'CATCACAGCACCCCCAGCC5' } \\
\text { 5'GAGGCTCTGGTTCAACTATGT3' }\end{array}$ & 144 & NM_001285669 & 99.9 \\
\hline
\end{tabular}

Table 2. Primer sequences and amplicon size of each gene analyzed in goat's peripheral blood mononuclear cells by quantitative real time PCR.

The reaction mixture was compound by $1 \mu$ cDNA (mean concentration of 10 $\mathrm{ng} / \mu \mathrm{l}), 10 \mu \mathrm{l}$ of Mix SYBRß Green, $0.4 \mu \mathrm{M}$ prime pair and $8.2 \mu \mathrm{l}$ of ultrapure water. A control reaction (NTC) was included in each essay to detect contaminations. The qPCR thermal cycling condition for all genes was the incubation stage at $95^{\circ} \mathrm{C}$ for 10 minutes; 40 cycles when temperature increases and occur the separation of double stranded ( $95^{\circ} \mathrm{C}$ for 15 seconds), annealing, primers bind to its homologous region in the cDNA (60 ${ }^{\circ} \mathrm{C}$ for 1 minute); dissociation curve. Relative quantification of a target gene was done using the Livak and Schmittgen (2001) method by comparing the expression level of the target gene with the reference gene (GAPDH). For each set of primers, the PCR efficiency was close to $100 \%$, all primer pairs used were confirmed for their PCR efficiency and specific products were checked by melt curve analysis and for appropriate size by $1.5 \%$ agarose gel electrophoresis. 
Statistical Analysis

Data was analyzed using the Statistical Analysis System (SAS, 2008). The normality was confirmed using the Shapiro - Wilk test. The analysis of environmental, weight and body condition score was conducted per treatment in each experimental day, pre and post parturition using the MIXED procedure of SAS. Milk yield data was normalized before statistical analysis using as covariable the mean of the previous lactation. Milk yield, energy corrected milk, milk composition, somatic cells count and microbiology were analyzed separately thought the distinct lactation weeks. These data were subjected to an analysis of variance by the MIXED procedure of SAS. The gene expression was done with analysis of variance by GLM procedure, in which was considered the fixed effects of treatment in each experimental day. When there was a significant effect, the means were compared using Fisher's test with the threshold for significance defined at $P \leq 0.05$.

\subsubsection{Results}

Lactation performance

The mean of $\mathrm{AT}$ for $\mathrm{HS}$ was $33.6^{\circ} \mathrm{C}$ and for $\mathrm{CT}$ was $23.3^{\circ} \mathrm{C}$ from $10: 00 \mathrm{~h}$ to 16:00 $\mathrm{h}$. The mean of THI for HS during the same hours was 82.27 and for CT was 70.07. Throughout all hours of the day, the AT and THI was always higher for HS than CT $(P<0.01)$ (Figure 1). The body weight (BW) and body condition score (BCS) during gestation and lactation are presented in Table 3. Comparing treatments, no difference was observed for BW and BCS during the gestation. However, on day 15 of lactation HS goats tended to have lower BW when compared to CT $(P=0.13)$, after these date no difference was observed during all lactation (Table 3). 


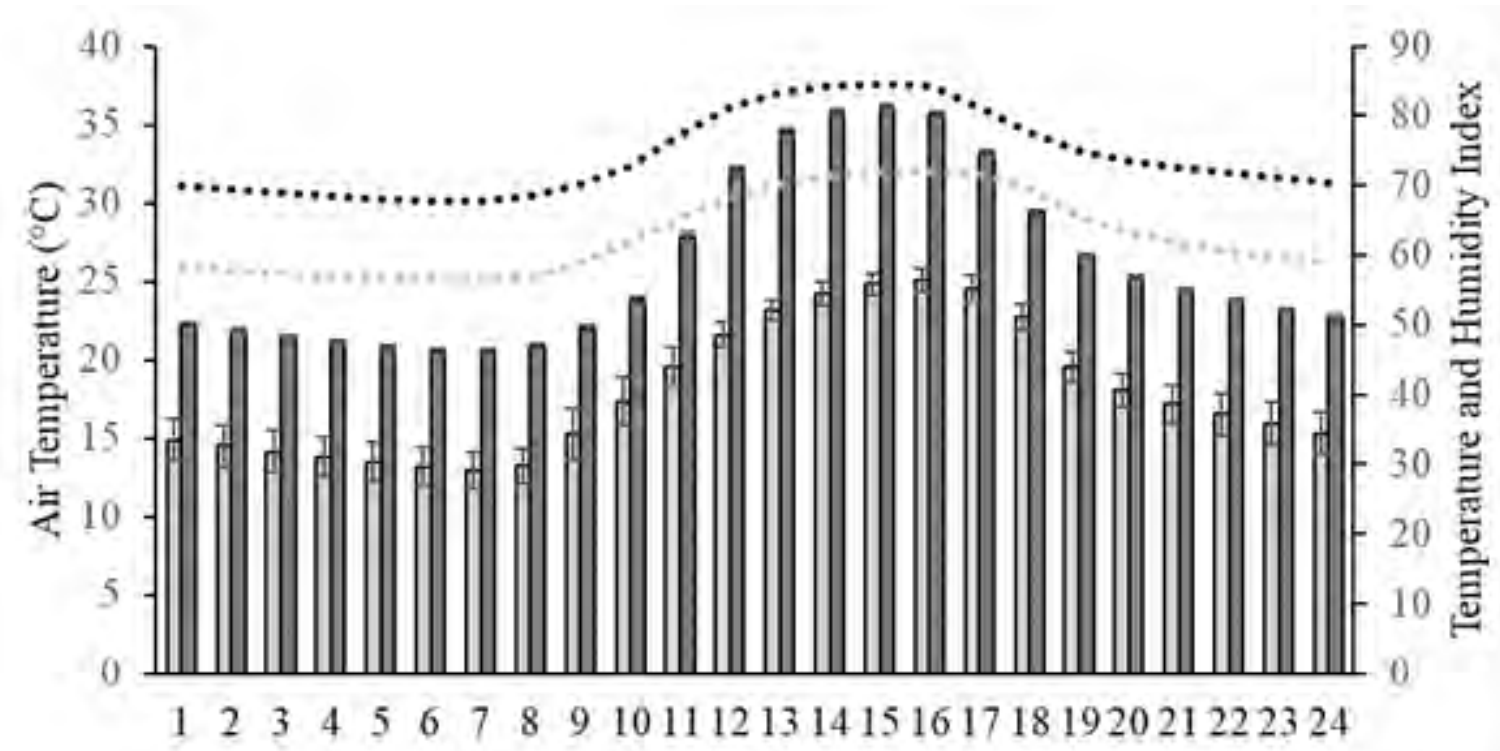

Hours

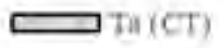

$\square$ Tล (HS)

N*W THI (CT)

…... Thit (HIs)

Figure 1. Mean and standard error of the mean of air temperature (AT) and Temperature and Humidity Index (THI) for HS and CT during the heat challenge per hour.

Table 3. Means followed by standard error of body weight (BW) and body condition score (BCS) at final gestation (days $-60,-45,-30$ and -15 ) and lactation (days 15, 30, 45 and 60$)$.

\begin{tabular}{|c|c|c|c|c|c|c|}
\hline \multirow[b]{2}{*}{ Days } & \multicolumn{2}{|c|}{ BW (kg) } & \multicolumn{4}{|c|}{ BCS } \\
\hline & CT & HS & P-value & CT & HS & P-value \\
\hline$\therefore-60$ & $73.68 \pm 2.80$ & $67.19 \pm 3.33$ & 0.15 & $2.82 \pm 0.15$ & $3.17 \pm 0.22$ & 0.19 \\
\hline-45 & $77.10 \pm 3.11$ & $70.59 \pm 3.29$ & 0.16 & $2.76 \pm 0.15$ & $2.95 \pm 0.16$ & 0.41 \\
\hline $\begin{array}{l}-30 \\
-15\end{array}$ & $\begin{array}{l}78.57 \pm 3.85 \\
84.82 \pm 3.27\end{array}$ & $\begin{array}{l}74.44 \pm 3.41 \\
76.47 \pm 3.76\end{array}$ & $\begin{array}{l}0.43 \\
0.11\end{array}$ & $\begin{array}{l}2.75 \pm 0.21 \\
3.03 \pm 0.22\end{array}$ & $\begin{array}{l}2.78 \pm 0.23 \\
2.97 \pm 0.19\end{array}$ & $\begin{array}{l}0.92 \\
0.82\end{array}$ \\
\hline 15 & $68.21 \pm 2.13$ & $62.09 \pm 3.16$ & 0.13 & $2.80 \pm 0.16$ & $2.82 \pm 0.15$ & 0.91 \\
\hline 30 & $68.79 \pm 2.35$ & $63.09 \pm 3.31$ & 0.18 & $2.69 \pm 0.24$ & $2.79 \pm 0.19$ & 0.74 \\
\hline 45 & $70.54 \pm 2.54$ & $66.34 \pm 3.25$ & 0.33 & $2.91 \pm 0.21$ & $2.91 \pm 0.17$ & 0.98 \\
\hline 60 & $78.21 \pm 2.90$ & $69.98 \pm 3.67$ & 0.10 & $3.09 \pm 0.26$ & $3.15 \pm 0.26$ & 0.87 \\
\hline
\end{tabular}

There was no effect of heat stress imposed during the gestation on milk yield measured during the 3 first weeks of lactation. However, between 4 to 12 weeks (plateau) CT goats showed a tendency to produce more milk than HS goats (2.31 
versus $\left.1.92 \mathrm{~kg} . d a y^{-1}, \mathrm{P}=0.06\right)$, showing a loss production of $16.8 \%$ of the milk. Furthermore, from 13 to 24 weeks (middle lactation), CT goats produced significantly more milk than HS goats (1.99 versus 1.47 kg.day $^{-1}, P=0.03$ ), showing a loss of $22.5 \%$ of the milk yield. There was no effect of heat stress on milk yield for HS goats after 25 lactation week (Figure 2).

There was no effect of treatment in milk protein (Table 4). Milk lactose was higher just 3 lactation weeks for CT goats when compared to HS goats. In contrast, milk fat just 12 lactation weeks was higher to HS goats when compared to CT. Although, HS goats presented higher somatic cells count (SSC) during all lactation than CT goats, there was no difference for total bacteria count, Staphylococcus sp. and for Enterobacteriaceae within treatments (Table 4).

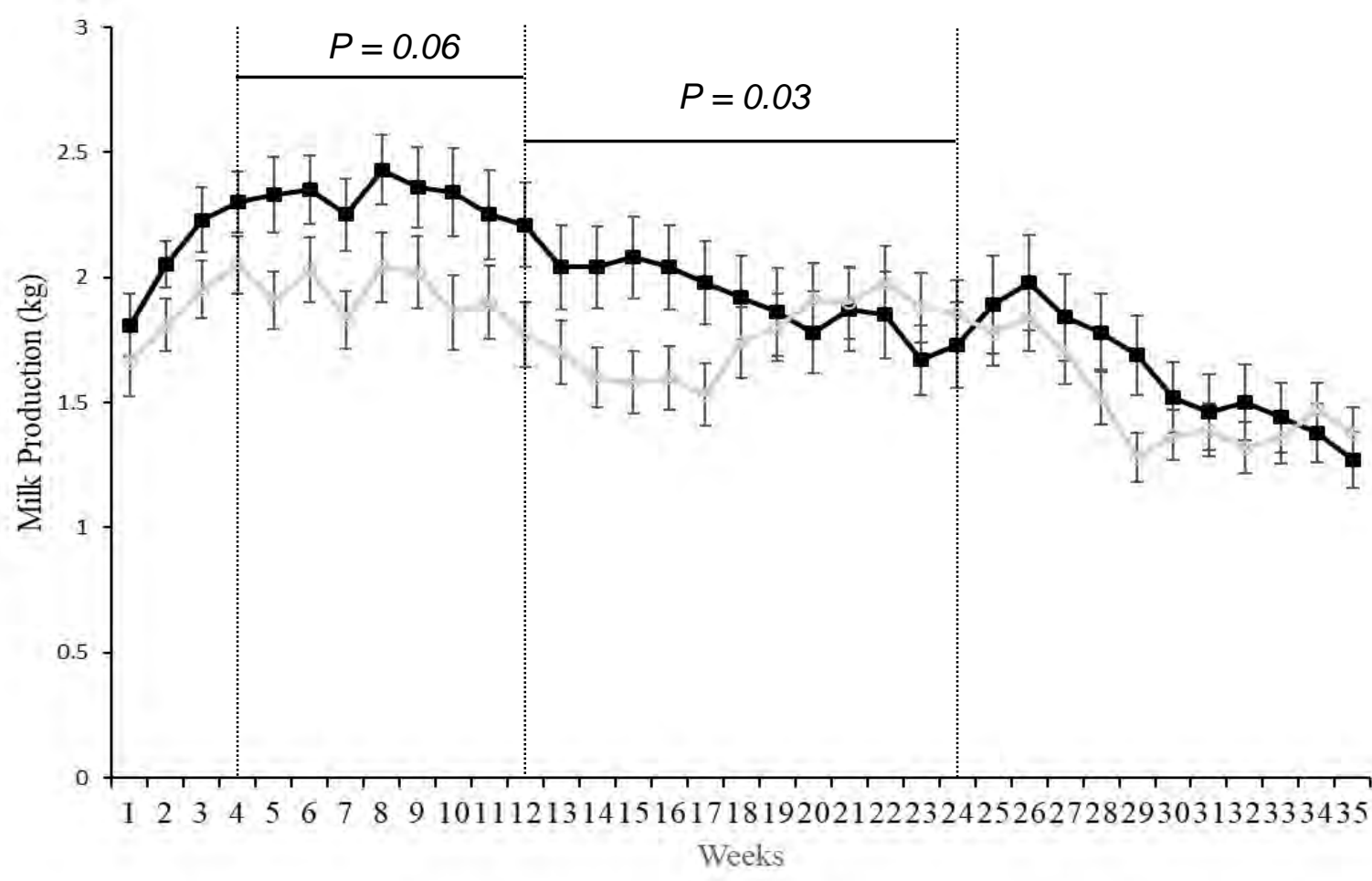

Figure 2. Mean and standard error of the mean of milk yield $(\mathrm{kg})$ for goats during 35 weeks of lactation for control (CT) and heat stress (HS) groups.

Mammary cellular responses

In tables 5 and 6 are represented the gene expression of mammary epithelial cells during gestation (days $-30,-15$ ) and lactation (days 15 and 30) for CT and HS goats. During gestation, there was significant effect of heat stress on the expression 
of p53 gene on day -30 , and the expression of Bax, HSP27and PRLr genes on day 15.

The effect of treatment during the lactation was observed only on early lactation. In fact, on day 15th of lactation, HS goats presented a higher expression of HSP27 gene when compared to CT goats. However, on same lactation day CT goats showed significantly higher expression of PRLr gene than HS goats. When compared to gestation, the expression of PRLr gene decrease for both groups and during lactation (day 15th) the CT goats showed significantly higher expression of PRLr gene than HS goats. Although, no effect of treatment was observed for $\mathrm{Bcl}-2$ and $\mathrm{Bax}$ during lactation, on day 30th, the ratio between them was higher for HS than CT. 
Table 4. Mean and standard error of the mean of milk yield, energy corrected milk (ECM), milk fat, protein and lactose, somatic cells count (SCC), total bacteria count, Staphylococcus sp. and Enterobacteriaceae on 35 weeks of goats' lactation considering the control (CT) and heat stress (HS) groups.

\begin{tabular}{|c|c|c|c|c|c|c|}
\hline \multirow{2}{*}{ Variable } & \multicolumn{3}{|c|}{ Weeks 1 to 3} & \multicolumn{3}{|c|}{ Weeks 4 to 12} \\
\hline & CT & HS & P-value & CT & HS & P-value \\
\hline ECM $(\mathrm{kg})$ & $2.17 \pm 0.17$ & $2.50 \pm 0.42$ & 0.47 & $2.22 \pm 0.12$ & $1.94 \pm 0.12$ & 0.09 \\
\hline Milk protein, \% & $3.49 \pm 0.03$ & $3.95 \pm 0.55$ & 0.42 & $3.17 \pm 0.01$ & $3.20 \pm 0.01$ & 0.12 \\
\hline Milk lactose, \% & $4.78 \pm 0.04$ & $4.63 \pm 0.05$ & 0.03 & $4.31 \pm 0.02$ & $4.35 \pm 0.02$ & 0.14 \\
\hline SCC log, cells $/ \mathrm{mL}$ & $5.56 \pm 0.04$ & $5.87 \pm 0.08$ & 0.01 & $5.62 \pm 0.02$ & $5.73 \pm 0.02$ & 0.01 \\
\hline Total bacteria count ${ }^{1}$, cfu/mL & $0.38 \pm 0.14$ & $6.83 \pm 4.84$ & 0.19 & $4.28 \pm 3.01$ & $27.36 \pm 20.45$ & 0.28 \\
\hline
\end{tabular}

\begin{tabular}{|c|c|c|c|c|c|c|}
\hline \multirow{2}{*}{ Variable } & \multicolumn{3}{|c|}{ Weeks 13 to 24} & \multicolumn{2}{|c|}{ Weeks 25 to 35} & \multirow[b]{2}{*}{$P$-value } \\
\hline & CT & HS & $P$-value & CT & HS & \\
\hline ECM $(\mathrm{kg})$ & $1.88 \pm 0.13$ & $1.65 \pm 0.10$ & 0.16 & $1.45 \pm 0.11$ & $1.24 \pm 0.07$ & 0.13 \\
\hline Milk protein, \% & $3.16 \pm 0.04$ & $3.19 \pm 0.01$ & 0.53 & $3.40 \pm 0.22$ & $3.18 \pm 0.02$ & 0.31 \\
\hline Milk lactose, \% & $4.23 \pm 0.02$ & $4.33 \pm 0.02$ & $<0.01$ & $4.33 \pm 0.02$ & $4.32 \pm 0.02$ & 0.85 \\
\hline SCC log, cells/mL & $5.54 \pm 0.02$ & $5.67 \pm 0.02$ & $<0.01$ & $5.48 \pm 0.02$ & $5.62 \pm 0.02$ & $<0.01$ \\
\hline Enterobacteriaceae, cfu/mL & $4.29 \pm 2.58$ & $1.14 \pm 0.70$ & 0.24 & $0.38 \pm 0.30$ & $1.39 \pm 1.11$ & 0.37 \\
\hline
\end{tabular}

\footnotetext{
${ }^{1}$ Values presented in $\times 10^{3} / \mathrm{mL}$. ${ }^{2}$ Some periods the count was insufficient for statistical analysis.
} 
Table 5. Gene expression of p53, Bax, Bcl2 and Bcl2/Bax for control (CT) heat stress (HS) during gestation (on days -30 and -15) and lactation (on days 15 and 30 ). ${ }^{*} \mathrm{P} \leq 0.05$ within treatments for the same day related to goats' partum.

\begin{tabular}{|c|c|c|c|c|c|c|c|c|c|c|c|c|}
\hline \multirow[b]{2}{*}{ Days } & \multicolumn{3}{|c|}{ p53 } & \multicolumn{3}{|c|}{ Bax } & \multicolumn{3}{|c|}{$\mathrm{Bcl}-2$} & \multicolumn{3}{|c|}{$\mathrm{Bcl}-2 / \mathrm{Bax}$} \\
\hline & CT & HS & P-value & CT & HS & P-value & CT & HS & P-value & CT & HS & P-value \\
\hline 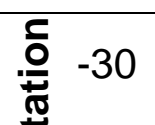 & $0.73 \pm 0.10$ & $0.99 \pm 0.06$ & 0.03 & $1.06 \pm 0.04$ & $0.98 \pm 0.09$ & 0.45 & $0.97 \pm 0.17$ & $1.14 \pm 0.16$ & 0.47 & $0.95 \pm 0.19$ & $1.18 \pm 0.15$ & 0.35 \\
\hline d & $0.95 \pm 0.11$ & $1.27 \pm 0.21$ & 0.23 & $1.00 \pm 0.06$ & $1.20 \pm 0.06$ & 0.03 & $1.00 \pm 0.16$ & $1.43 \pm 0.17$ & 0.08 & $1.01 \pm 0.13$ & $1.23 \pm 0.17$ & 0.32 \\
\hline$\stackrel{\frac{c}{0}}{\frac{0}{\sigma}} 15$ & $0.62 \pm 0.10$ & $0.71 \pm 0.08$ & 0.49 & $0.92 \pm 0.07$ & $0.88 \pm 0.03$ & 0.58 & $0.67 \pm 0.09$ & $0.71 \pm 0.12$ & 0.72 & $0.72 \pm 0.06$ & $0.83 \pm 0.12$ & 0.42 \\
\hline త్ర 30 & $0.99 \pm 0.09$ & $0.92 \pm 0.09$ & 0.58 & $1.08 \pm 0.06$ & $0.95 \pm 0.06$ & 0.15 & $1.12 \pm 0.15$ & $1.36 \pm 0.15$ & 0.28 & $1.03 \pm 0.11$ & $1.43 \pm 0.14$ & 0.03 \\
\hline
\end{tabular}


Table 6. Gene expression of HSP27, HSP70 and PRLr for control (CT) heat stress (HS) during gestation (on days -30 and -15) and lactation (on days 15 and 30 ). ${ }^{*} \mathrm{P} \leq 0.05$ within treatments for the same day related to goats' partum.

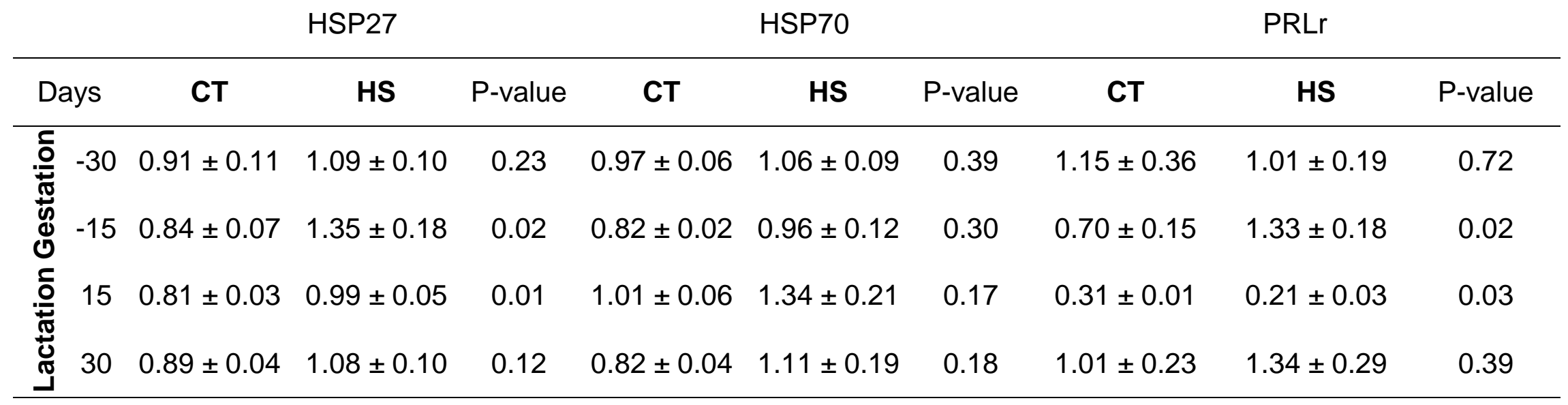




\subsubsection{Discussion}

The HS goats were exposed to an environment in which the thermal load was always higher than the CT. Therefore, the heat stress imposed at last third of gestation was considered above the comfort temperature for goats $\left(20^{\circ} \mathrm{C}\right.$ to $\left.30^{\circ} \mathrm{C}\right)$ (SILVA, 2000; PEREIRA et al., 2011). In the present study, the THI were 82.27 and 70.04 for HS and CT, respectively. For goats these values were characterized as alert condition for HS and normal condition for CT (SILANIKOVE and KOLUMAN, 2015). In Saanen and Alpine goats moderate to severe heat stress was confirmed when THI was within 79 and 89 (SANO et al., 1985; BROWN et al. 1988).

In the present study, no effect of heat stress was observed on BW and BCS during the final gestation and lactation. Similar results were found in Holstein cows when submitted to cooling during late gestation (AVENDAÑO-REYES et al., 2006; URDAZ et al., 2006). Although, the dry matter intake was not controlled in our experiment, lower DMI was related to heat stress by other authors (TAO et al. 2012; HAMZAOUI et al. 2012). The same authors demonstrated that cows cooled during pre-parturition increased DMI post-parturition and had higher BW in early lactation. These findings may explain why HS goats tended to had lower BW during lactation.

HS goats presented a tendency $(P=0.06)$ for lower milk yield from weeks 4 to 12 week and significant reduction of milk yield from 13 to 24 weeks when compared to CT goats $(P=0.03)$. Generally, goats are recognized by their better adaptation to heat stress than cows (SILANIKOVE, 2000b; SHILJA et al., 2016; SARANGI, 2018). Otherwise, the experimental goats, when subjected to heat stress at final gestation, showed lower milk production from 1 to 17 lactation weeks, that correspond a loss of $16 \%$ or $39.5 \mathrm{Kg}$ of milk during entire experimental lactation. In cows, was observed a reduction of $5.3 \%$ on milk yield in the first 90 days of lactation when the animals were not cooled during the dry period and final gestation (ADIN et al., 2009). Similarly, heat stressed cows during the dry period and final gestation reduced between 4 to 5 kg.day ${ }^{-1}$ of milk considering the entire lactation period (TAO and DAHL, 2013). In fact, to provide thermal comfort during pre-parturition increase profitability per cow to

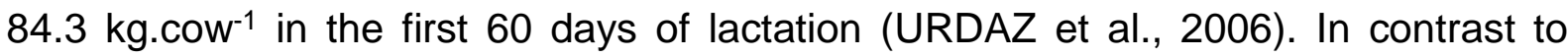
cows, there was no effect of heat stress on milk yield for HS goats after 25 lactation 
week. These finding confirms the negative impact of heat stress in milk yield (ADIN et al., 2009; Do AMARAL et al., 2009; TAO et al., 2011, 2012; KARIMI et al., 2015).

In relation to milk composition, lactose in milk was lower for HS goats just 12 lactation weeks than CT goats. In contrast, HS goats presented higher fat percentage in just 12 lactation weeks when compared to CT treatment. However, no difference was observed for protein content. In other studies, with goats the heat stress reduced fat, protein and lactose during lactation when compared to goats (BRASIL et al., 2000; AVENDAÑO-REYES et al., 2006; HAMZAOUI et al., 2013). Other authors, argued that heat stress had no effect on fat mobilization in Holstein cows, but there was a shift to carbohydrate metabolism (LAMP et al. 2015). In the mammary gland, the non-cooled dry cows exhibited higher gene expression of acetyl CoA carboxylase and fatty acid synthetase that guide for fatty acid synthesis (ADIN et al., 2009). These findings may explain the reduction of lactose and increase of fat percentage in milk for HS goats.

Somatic cell count was greater for HS than CT during all lactation, and SCC has been widely measured in dairy ruminants as a predictor of udder health and intramammary infections (BAUDRY et al., 1997; SHARIF and MUHAMMAD, 2008; SANT'ANNA and PARANHOS da COSTA, 2011). When compared to cows, goat present higher number of cells in milk and health dairy goats had a larger range of SCC reaching a count 1 million cells. $\mathrm{mL}^{-1}$ without any relations with to mastitis (PAAPE et al., 2001; RAYNAL-LJUTOVACA et al., 2007; BARRÓN-BRAVO et al., 2013). In goat, although udder heath is related to SCC other numerical parameters need be taking in account (LEITNER et al., 2008). In fact, HS and CT goats presented less than 600,000 SCC in all lactation phases, been considered health. Indeed, no difference was observed between treatments for the total bacteria count, Staphylococcus sp. and Enterobacteriaceae count, confirming that the reduction on milk yield was not associated with mastitis. Similar to other study that did not observed differences on SCC and microbiology status after different stressors exposition in Saanen goats (BOMFIM et al., 2018).

Previous to parturition, the HS presented higher expression of p53 on day -30 of gestation, and p53 is an apoptotic protein induced in response to cellular damage during mammary gland involution (LEVINE, 1997; GREEN and STREULI, 2004; 
AVIVAR-VALDERAS et al., 2014). The higher expression of p53 gene was observed in bovine mammary epithelial cells maintain in vitro with at $42^{\circ} \mathrm{C}$ ( $\mathrm{HU}$ et al., 2016). Furthermore, p53 accumulated in mammalian cells during the environmental stress and was related to their DNA damage (OHNISHI et al., 1999).

On day -15 of gestation, there was a higher expression of Bax gene a proapoptotic factor, no difference was observed on Bcl-2 gene an anti-apoptotic and on $\mathrm{Bcl}-2 / \mathrm{Bax}$ ratio. The higher expression of Bax gene can be related to expression of p53 gene was reported previously (GREEN and STREULI, 2004). According to the same authors, the apoptosis regulation of mammary cells is a multifactorial event and depends on various pathways (GREEN and STREULI, 2004). However, in buffalo the expression of Bax gene increased and Bcl-2 gene decreased immediately after heat stress (KAPILA et al., 2016). Similar to our results, Bomfim et al. (2018) reported that cortisol increased Bax expression without Bcl-2 change of mammary epithelial cells (MEC) in vitro. In contrast to studies discussed above, a downregulation of Bax was observed in mammary epithelial cell of cows submitted to heat stress in vitro (HU et al., 2016).

Even though, the HS goats had greater gene expression of p53 and Bax both considered as apoptotic factors, epithelial cells also presented higher expression of HSP27 considered anti-apoptotic factor just before and after parturition when compared to CT goats. As HSP27 is an anti-apoptotic factor associated with cytochrome $\mathrm{c}$ and inhibits of caspase 3 activation, blocking cytoskeletal disruption and acting as anti-oxidant (LANNEAU et al., 2007). For that reason, HSP27 gives support to proliferation when several signaling pathways of apoptosis are initiated. Interestingly, even after the end of heat stress HSP27 was upregulated on HS, carrying this protective mechanism between final gestation and early lactation.

In vitro, HSP70 and other HSPs (HSPA6, HSPB8, DNAJB2) were expressed in buffalo mammary epithelial cell exposed to thermal stress at $42^{\circ} \mathrm{C}$ (KAPILA et al., 2016). Although, HSP70 plays important role to recovery cells damage and inhibit different apoptosis pathways (OHNISHI et al., 1999; LANNEAU et al., 2007). In this present study, no difference between treatments were observed on HSP70 expression. Consequently, HSP27 was considered an interesting biomarker to study a long-term the effect of heat stress in mammary epithelial cell. 
In the present study, the expression of PRLr gene was influenced by treatments at final gestation to early lactation (days -15 and 15). PRLr during heat stress was upregulated in mammary epithelial cells, apparently as a protective function during final gestation to early lactation characterized by intensive cell proliferation (FLINT et al., 2001; ACCORSI et al., 2002). Moreover, the higher expression of PRLr gene can also be related to acclimatization process (ALAMER, 2011), because the interaction between the prolactin and its receptor is involved in regulation of several ions, extracellular volume and body fluid, improving animal responses related to heat dissipation during several weeks.

Although after parturition there was a decrease on PRLr expression for both HS and CT treatment when compared to end lactation, CT goats showed significantly higher expression of PRLr gene than HS goats. In fact, this is one of the reasonable mechanisms underlying the lower milk production on subsequent lactation to $\mathrm{HS}$ goats when compared to CT goats. Some authors suggested an inverse relation between prolactin concentration and its receptor during environmental changes (AUCHTUNG et al., 2005; WALL et al., 2005; DAHL, 2008; TAO et al., 2011). However, our results are concerning about the lower expression of PRLr gene and reduction of milk production, it suggests that $\mathrm{HS}$ reduced the milk synthesis by epithelial cells, affecting milk productivity of goats. In fact, prolactin is directly related to capacity of milk synthesis by epithelial cells on final gestation and early lactation (COLLIER et al., 1982; TUCKER, 2000; TAO et al., 2011). For this reason, the changes observed for HS goats also can be linked to mammary development during the final gestation, when there is increase of proliferation rate of mammary epithelial cells (ROWSON et al., 2012). In fact, the negative effect proliferation impairments and reduction of milk yield have been reported by other authors (TAO and DAHL, 2013). 


\subsection{Conclusions}

In conclusion, heat stress at final gestation reduces milk yield and increases somatic cells count on subsequent lactation. The changes were related to the highest expression of p53, Bax (pro-apoptotic) and HSP27 (anti-apoptotic factor) genes and lower expression of PRLr in heat stress goats. These findings, point it out the negative consequences of heat stress on mammary function and the necessity to provide thermal comfort previous to parturition. However, further researches need be done to elucidate cellular response to heat stress on goat's mammary epithelial cells and their impact on synthesis function. 


\section{References}

ACCORSI, P. A. et al. Role of prolactin, growth hormone and insulin-like growth factor 1 in mammary gland involution in the dairy cow. Journal of Dairy Science, $v$. 85, n. 3, p. 507-513, 2002.

ADIN, G. et al. Effects of cooling dry cows under heat load conditions on mammary gland enzymatic activity, intake of food and water, and performance during the dry period and after parturition. Livestock Science, v. 124, n. 1-3, p. 189-195, 2009.

ALAMER, M. The role of prolactin in thermoregulation and water balance during heat stress in domestic ruminants. Asian Journal of Animal and Veterinary Advances, v. 6, n. 12, p. 1153-1169, 2011.

AUCHTUNG, T. L. et al. Effects of photoperiod during the dry period on prolactin, prolactin receptor, and milk production of dairy cows. Journal of Dairy Science, $v$. 88, n. 1, p. 121-127, 2005.

AVENDAÑO-REYES, L. et al. Effect of cooling Holstein cows during the dry period on postpartum performance under heat stress conditions. Livestock Science, v. 105, n. 1-3, p. 198-206, 2006.

AVIVAR-VALDERAS, A.; WEN, H. C.; AGUIRRE-GHISO, J. A. Stress signaling and the shaping of the mammary tissue in development and cancer. Oncogene, v. $33, n$. 48, p. 5483-90, 2014.

BAHR, B.; GALAN, H. L.; ARROYO, J. A. Decreased expression of phosphorylated placental heat shock protein 27 in human and ovine intrauterine growth restriction (IUGR). Placenta, v. 35, n. 6, p. 404-410, 2014.

BARRÓN-BRAVO, O. G. et al. Losses in milk yield, fat and protein contents according to different levels of somatic cell count in dairy goats. Small Ruminant Research, v. 113, n. 2-3, p. 421-431, 2013.

BELHADJ SLIMEN, I. et al. Heat stress effects on livestock: molecular, cellular and metabolic aspects, a review. Journal of Animal Physiology and Animal Nutrition, v. 100, n. 3, p. $401-412,2016$. 
BOMFIM, G. F. et al. Effect of acute stressors, adrenocorticotropic hormone administration, and cortisol release on milk yield, the expression of key genes, proliferation, and apoptosis in goat mammary epithelial cells. Journal of Dairy Science, v. 101, n. 7, p. 6486-6496, 2018.

BRASIL, L. H. A. et al. Efeitos do estresse térmico sobre a produção, composição química do leite e respostas termorreguladoras de cabras da raça alpina. Revista Brasileira de Zootecnia, v. 29, n. 6, p. 1632-1641, 2000.

BUFFINGTON, D. E. et al. Black Globe-Humidity Index (BGHI) as comfort equation for dairy cows. American Society of Agricultural Engineers, v. 81, n. 0001-2351, p. 711-714, 1981.

CAPUCO, A. V.; AKERS, R. M.; SMITH, J. J. Mammary growth in Holstein cows during the dry period: quantification of nucleic acids and histology. Journal of Dairy Science, v. 80, n. 3, p. 477-487, 1997.

COLLIER, R. J. et al. Influences of environment and its modification on dairy animal health and production. Journal of Dairy Science, v. 65, n. 11, p. 2213-2227, 1982.

DAHL, G. E. Effects of short day photoperiod on prolactin signaling in dry cows: A common mechanism among tissues and environments? Journal of Animal Science, v. 86 , n. suppl_13, p. 10-14, 2008.

DANGI, S. S. et al. Modulatory effect of betaine on expression dynamics of HSPs during heat stress acclimation in goat (capra hircus). Gene, v. 575, n. 2, p. 543-550, 2016.

Do AMARAL, B. C. et al. Heat-stress abatement during the dry period: Does cooling improve transition into lactation? Journal of Dairy Science, v. 92, n. 12, p. 59885999, 2009.

FLINT, D. J. et al. Control of mammary involution by insulin-like growth factor binding proteins: role of prolactin. Livestock Production Science, v. 70, n. 1-2, p. 115-120, 2001.

FLORES, A. et al. Effects of rumen-protected methionine on milk production of dairy goats. Italian Journal of Animal Science, v. 8, n. 2, p. 271-275, 2009. 
GREEN, K. A.; STREULI, C. H. Apoptosis regulation in the mammary gland. Cellular and Molecular Life Sciences, v. 61, n. 15, p. 1867-83, 2004.

HAMZAOUI, S. et al. Milk production losses in early lactation dairy goats under heat stress. Joint Annual Meeting. Anais...Phoenix, Arizone: ADSA, 2012

HAMZAOUI, S. et al. Physiological responses and lactational performances of latelactation dairy goats under heat stress conditions. Journal of Dairy Science, v. 96, n. 10, p. 6355-6365, 2013.

HOOPER, H. B. et al. Acute heat stress induces changes in physiological and cellular responses in Saanen goats. International Journal of Biometeorology, v. 62, n. 12, p. 2257-2265, 2018.

$\mathrm{HU}, \mathrm{H}$. et al. Heat-induced apoptosis and gene expression in bovine mammary epithelial cells. Animal Production Science, v. 56, n. 5, p. 918, 2016.

IPCC. Climate Change 2013: The physical science basis. Contribution of working group I to the fifth assessment report of the Intergovernmental Panel on Climate Change; Cambridge University Press, 2013.

KADZERE, C. T. et al. Heat stress in lactating dairy cows: a review. Livestock Production Science, v. 77, p. 59-91, 2002.

KAPILA, N. et al. Impact of heat stress on cellular and transcriptional adaptation of mammary epithelial cells in Riverine buffalo (bubalus bubalis). PloS One, v. 11, n. 9, p. e0157237, 2016.

KARIMI, M. T. et al. Late-gestation heat stress abatement on performance and behavior of Holstein dairy cows. Journal of Dairy Science, v. 98, n. 10, p. 6865-75, 2015.

LAMP, O. et al. Metabolic heat stress adaption in transition cows: Differences in macronutrient oxidation between late-gestating and early-lactating German Holstein dairy cows. Plos One, v. 10, n. 5, p. e0125264, 2015.

LANNEAU, D. et al. Apoptosis versus cell differentiation: role of heat shock proteins HSP90, HSP70 and HSP27. Prion, v. 1, n. 1, p. 53-60, 2007. 
LEITNER, G.; SILANIKOVE, N.; MERIN, U. Estimate of milk and curd yield loss of sheep and goats with intrammamary infection and its relation to somatic cell count. Small Ruminant Research, v. 74, n. 1-3, p. 221-225, 2008.

LEVINE, A. J. p53, the cellular gatekeeper for growth and division. Cell, v. 88, n. 3, p. 323-31, 1997.

LIVAK, K. J.; SCHMITTGEN, T. D. Analysis of relative gene expression data using real-time quantitative PCR and the 2(-Delta Delta C(T)) Method. Methods, v. 25, n. 4, p. 402-8, 2001.

MADER, T.; DAVIS, M. Environmental factors influencing heat stress in feedlot cattle. Journal of Animal Science, v. 84, n. 3, p. 712-719, 2006.

MOBERG, G. P.; MENCH, J. A. The biology of animal stress: basic principles and implications for animal welfare. Wallingford: $\mathrm{CABI}, 2000$.

MOHANARAO, G. J. et al. HSP70 family genes and HSP27 expression in response to heat and cold stress in vitro in peripheral blood mononuclear cells of goat (capra hircus). Small Ruminant Research, v. 116, n. 2-3, p. 94-99, 2014.

NEUER, A. et al. The role of heat shock proteins in reproduction. Human Reproduction Update, v. 6, n. 2, p. 149-59, 2000.

NØRGAARD, J. $V$ et al. Cellular mechanisms in regulating mammary cell turnover during lactation and dry period in dairy cows. Journal of Dairy Science, v. 91, n. 6, p. 2319-27, 2008.

OHNISHI, T. et al. DNA damage formation and p53 accumulation in mammalian cells exposed to the space environment. Biological Sciences in Space, v. 13, n. 2, p. 82-7, 1999.

OZAYDIN, T. et al. Immunohistochemical distribution of heat shock protein 70 and proliferating cell nuclear antigen in mouse placenta at different gestational stages. Microscopy Research and Technique, v. 79, n. 4, p. 251-257, 2016.

PAAPE, M. J. et al. Milk somatic cells and lactation in small ruminants. Journal of Dairy Science, v. 84, p. E237-E244, 2001. 
PAAPE, M. J. et al. Monitoring goat and sheep milk somatic cell counts. Small Ruminant Research, v. 68, n. 1-2, p. 114-125, 2007.

PEREIRA, G. M. et al. Avaliação do comportamento fisiológico de caprinos da raça Saanen no semiárido paraibano. Revista Verde de Agroecologia e

Desenvolvimento Sustentável, v. 6, n. 1, p. 83-88, 2011.

RAYNAL-LJUTOVACA, K. et al. Somatic cells of goat and sheep milk: Analytical, sanitary, productive and technological aspects. Small Ruminant Research, v. 68, n. 1-2, p. 126-144, 2007.

ROWSON, A. R. et al. Growth and development of the mammary glands of livestock: a veritable barnyard of opportunities. Seminars in Cell \& Developmental biology, v. 23, n. 5, p. 557-66, 2012.

SALAMA, A. A. K. et al. Different levels of response to heat stress in dairy goats. Small Ruminant Research, v. 121, n. 1, p. 73-79, 2014.

SANO, H.; AMBO, K.; TSUDA, T. Blood glucose kinetics in whole body and mammary gland of lactating goats exposed to heat. Journal of Dairy Science, v. 68, n. 10, p. 2557-64, Oct. 1985.

SANT'ANNA, A C.; PARANHOS DA COSTA, M. J. R. The relationship between dairy cow hygiene and somatic cell count in milk. Journal of Dairy Science, v. 94, n. 8, p. 3835-44, 2011.

SARANGI, S. Adaptability of goats to heat stress: A review. The Pharma Innovation Journal, v. 7, n. 4, p. 1114-1126, 2018.

SHARIF, A.; MUHAMMAD, G. Somatic cell count as an indicator of udder health status under modern dairy production: a review. Veterinary Journal, v. 28, n. 4, p. 194-200, 2008.

SHILJA, S. et al. Adaptive capability as indicated by behavioral and physiological responses, plasma HSP70 level, and PBMC HSP70 mRNA expression in Osmanabadi goats subjected to combined (heat and nutritional) stressors. International Journal of Biometeorology, v. 60, n. 9, p. 1311-1323, 2016. 
SHOCHET, G. E. et al. Heat shock protein-27 (HSP27) regulates STAT3 and elF4G levels in first trimester human placenta. Journal of Molecular Histology, v. 47, n. 6, p. 555-563, 2016.

SILANIKOVE, N. Effects of heat stress on the welfare of extensively managed domestic ruminants. Livestock Production Science, v. 67, p. 1-18, 2000a.

SILANIKOVE, N. The physiological basis of adaptation in goats to harsh environments. Small Ruminant Research, v. 35, n. 3, p. 181-193, 2000 b.

SILANIKOVE, N.; KOLUMAN, D. N. Impact of climate change on the dairy industry in temperate zones: Predications on the overall negative impact and on the positive role of dairy goats in adaptation to earth warming. Small Ruminant Research, v. 123, n. 1, p. 27-34, 2015.

SILVA, R. G. Introdução à bioclimatologia animal. São Paulo: Ed. Nobel, 2000.

TAO, S. et al. Effect of heat stress during the dry period on mammary gland development. Journal of Dairy Science, v. 94, n. 12, p. 5976-5986, 2011.

TAO, S. et al. Effect of cooling heat-stressed dairy cows during the dry period on insulin response. Journal of Dairy Science, v. 95, n. 9, p. 5035-5046, 2012.

TAO, S.; DAHL, G. E. Invited review: heat stress effects during late gestation on dry cows and their calves. Journal of Dairy Science, v. 96, n. 7, p. 4079-93, 2013.

TUCKER, H. A. Hormones, mammary growth, and lactation: a 41-Year perspective. Journal of Dairy Science, v. 83, n. 4, p. 874-884, 2000.

URDAZ, J. H. et al. Technical Note: Effects of adding shade and fans to a feedbunk sprinkler system for preparturient cows on health and performance. Journal of Dairy Science, v. 89, n. 6, p. 2000-2006, 2006.

WALL, E. H. et al. Exposure to short day photoperiod during the dry period enhances mammary growth in dairy cows. Journal of Dairy Science, v. 88, n. 6, p. 19942003, 2005. 
WEST, J. Effects of heat-stress on production in dairy cattle. Journal of Dairy Science, v. 86, n. 6, p. 2131-44, 2003. 


\section{ADDENDUM}

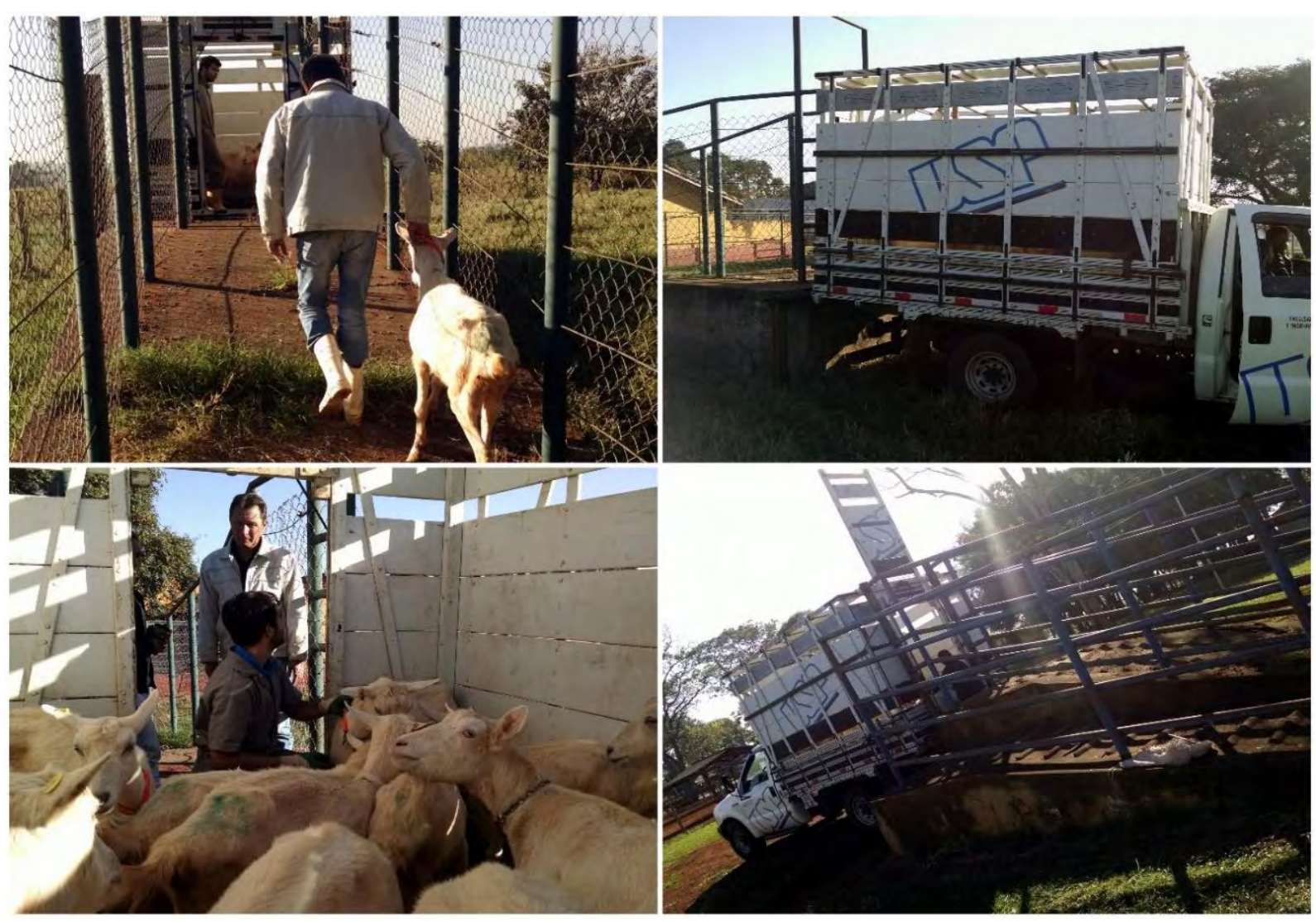

Addendum A. Animals transport to the climatic chamber and thermal neutral pens. (Source: Own Authorship) 


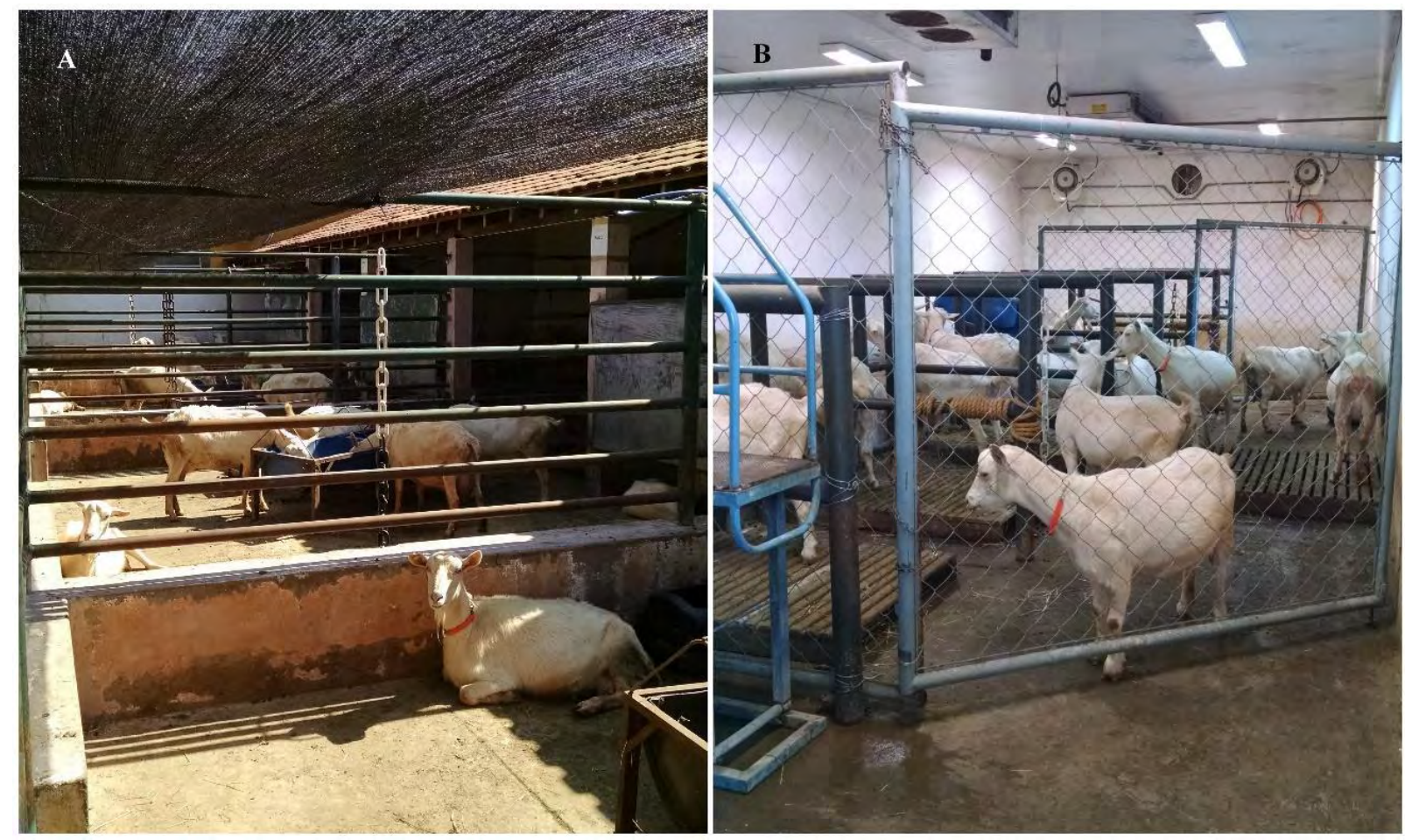

Addendum B. Control group housed in the shaded área (A), heat stress group housed in the climatic chamber (B). (Source: Own Authorship) 


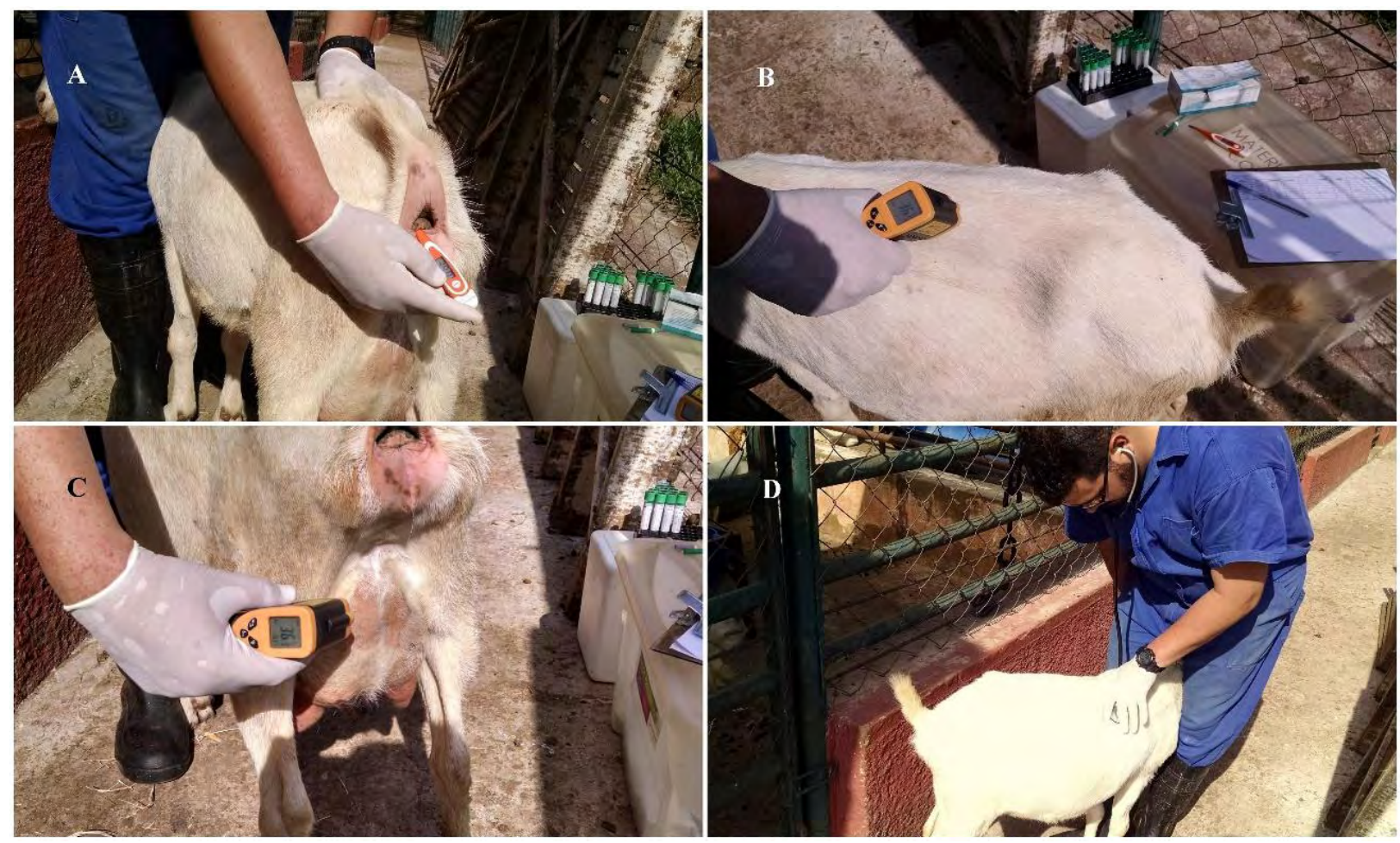

Addendum C. Physiologcial paramenters measurements: rectal temperature (A), dorsal superficial temperature (B), mammary superficial temperature (C) ans respiratory frequency (D). (Source: Own Authorship) 


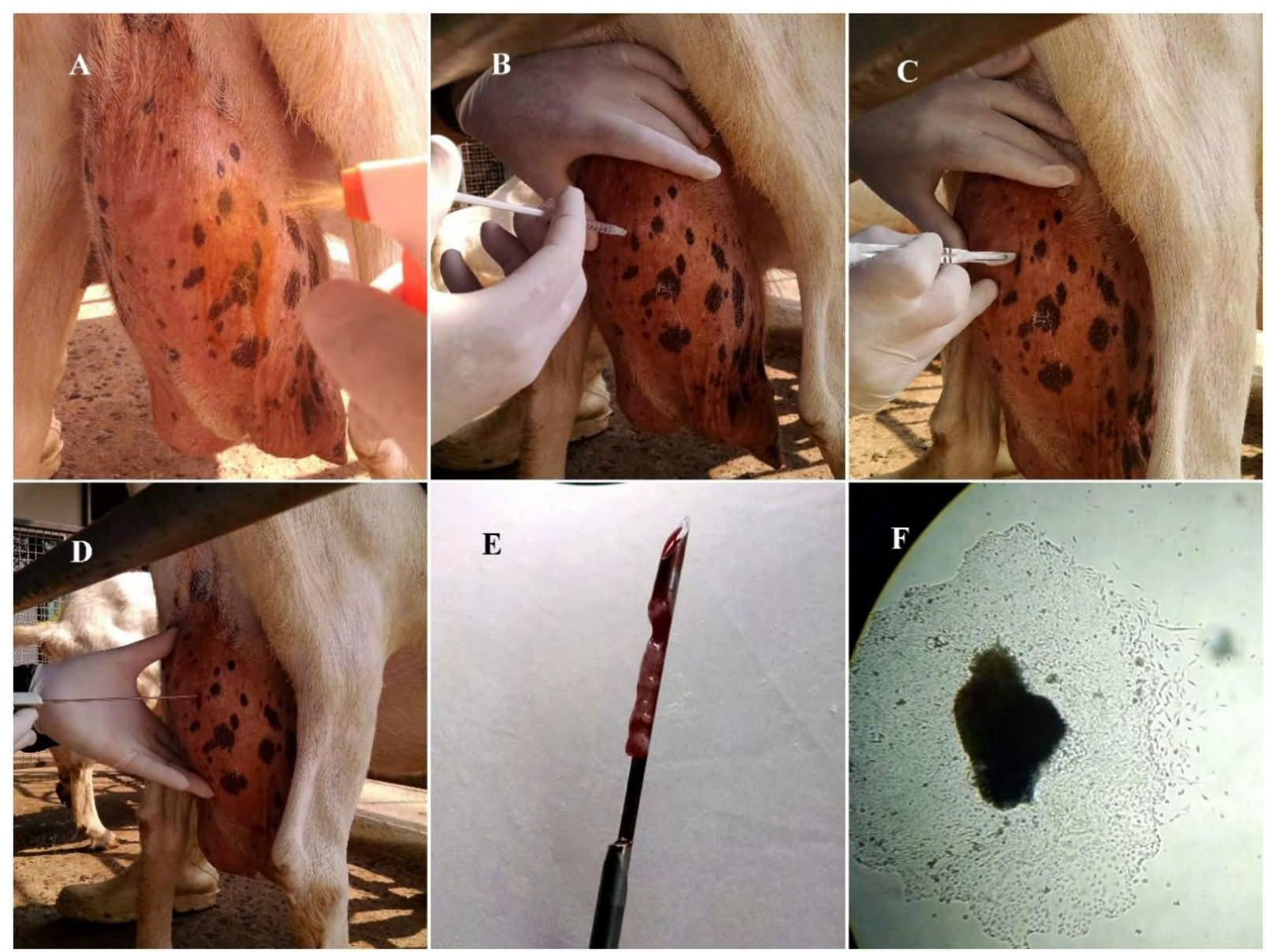

Addendum D. Biopsy procedures to sample mammary gland tessue, pre-cirurgical procedures (A), local anestesia (B) skin incition (C), biopsy needle insertion (D), mammary tissue sampled (E), microscopy from the mammary tissue cell culture (F). (Source: Own Authorship) 

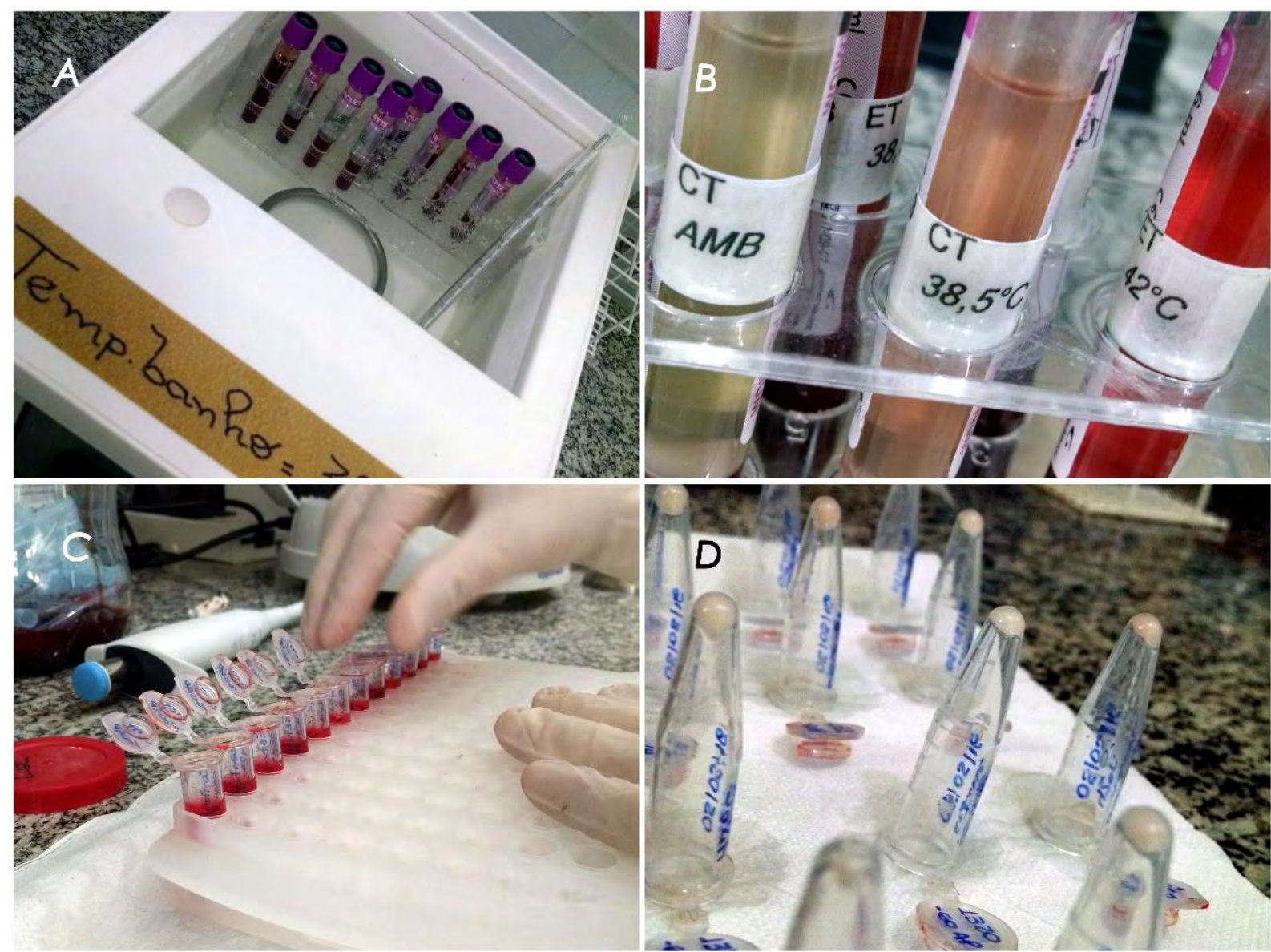

Addendum E. In vitro heat treatment of total blood (A-B), hemolysis procedure (C), peripheral blood mononuclear cells obtained (D). (Source: Own Authorship) 


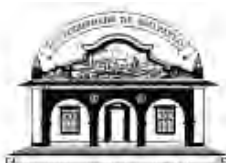

UNIVERSIDADE DESÃO PAULO

faculdade de Zootecria e Engenharia de Alimentos

Comite de Ética em Pesquisa da FZEA

FEDT TSP

\section{CERTIFICADO}

Certificamos que o Projeto intitulado "Eleito do estresse térmico durante a fase final da gestaçăo na apoptose da glândula mamária de cabras Saanen e desempenho dos cabritos", protocolado sob o CEUA n 3709280316 , sob responsabilidade de Henrique Barbosa Hooper e equipe. Priscila Doș Santos Silva; Prof. Dr. Joāo Alberto Negrâo; Giovana Krempel Fonseca Merighe. Sandra Aparecida De Oliveira - que envolve a produção, manutenção e/ou utilização de animais pertencentes ao filo Chordata, subfilo Vertebrata (exceto o homem), para fins de pesquisa cientifica (ou ensino) - encontra-se de acordo com os preceitos da Lei 11.794, de 8 de outubro de 2008 , com o Decreto 6.899, de 15 de julho de 2009, com as normas editadas pelo Conselho Nacional de Controle da Experimentação Animal (CONCEA), e foi aprovado pela Comissâo de Ética no Uso de Animais da Facuidade de Zootecnia e Engenharia de Alimentos da Universidade de São Paulo - FZEA/USP em reunião de 22/06/2016.

We certify that the proposal "Effect of heat stress during late pregnancy on mammary gland's apoptosis of Saanen goats and offspring's performance", utilizing 60 Caprines (males and females), protocol number CEUA 3709280316, under the responsibility of Henrique Barbosa Hooper and team; Priscila Dos Santos Silva; Prof. Dr. João Alberto Negrāo: Giovana Krempel Fonseca Merighe, Sandra Aparecida De Oliveira - which involves the production, maintenance and/or use of animals belonging to the phylum Chordata, subphylum Vertebrata (except human beings), for scientific research purposes (or teaching) - it's in accordance with Law 11.794, of October 82008 , Decree 6899, of July 15, 2009, with the rules issued by the National Council for Control of Animal Experimentation (CONCEA), and was approved by the Ethic Committee on Animal Use of the School of Animal Science and Food Engineering of São Paulo University in the meeting of 06/22/2016.

Addendum E. Ethic committee approval with protocol number 3709280316, emitted by the Ethic Committee on Animal Use of the School of Animal Science and Food Engineering of São Paulo University. 